\title{
High-Level Waste Tanks Multi-Dimensional Contaminant Transport Model Development
}

by

L. B. Collard

Westinghouse Savannah River Company

Savannah River Site

Aiken, South Carolina 29808

G. P. Flach

This paper was prepared in connection with work done under the above contract number with the $U$. S.

Department of Energy. By acceptance of this paper, the publisher and/or recipient acknowledges the U.S. Government's right to retain a nonexclusive, royalty-free license in and to any copyright covering this paper, along with the right to reproduce and to authorize others to reproduce all or part of the copyrighted paper. 
KEYWORDS: HIGH-LEVEL WASTE TANKS CONTAMINANT TRANSPORT SEEPLINE ANALYSIS

RETENTION : Permanent

HIGH-LEVEL WASTE TANKS

MULTI-DIMENSIONAL CONTAMINANT TRANSPORT MODEL DEVELOPMENT

Authors

Leonard B. Collard

Gregory P. Flach

Westinghouse Savannah River Company Savannah River Site Aiken, SC 29808

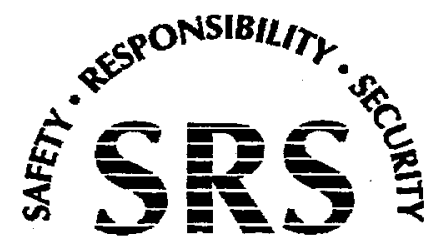




\section{DISCLAIMER}

This report was prepared as an account of work sponsored by an agency of the United States Government. Neither the United States Government nor any agency thereof, nor any of their employees, makes any warranty, express or impliecl, or assumes any legal liability or responsibility for the accuracy, completeness, or usefulness of any information, apparatus, product, or process disclosed, or represents that its use would not infringe privately owned rights. Reference herein to any specific commercial product, process, or service by trade name, trademark, manufacturer, or otherwise does not necessarily constitute or imply its endorsement, recommendation, or favoring by the United States Government or any agency thereof. The views and opinions of authors expressed herein do not necessarily state or reflect those of the United States Government or any agency thereof.

This report has been reproduced directly from the best avitilable copy.

Available to DOE and DOE contractors from the Office of Scientific and Technical Information, P.O. Box 62, Oak Ridge, TN 37831; prices available from (615) 576-8401.

Available to the public from the National Technical Information Service, U.S. Department of Commerce, 5285 Port Royal Road, Springfield, VA 22161. 


\section{DISCLAIMER}

Portions of this document may be illegible in electronic image products. Images are produced from the best available original document. 
KEYWORDS: HIGH-IEVEL WASTE TANKS CONTAMINANT TRANSPORT SEEPLINE ANALYSIS

RETENTION: Permanent

HIGH-LEVEL WASTE TANKS

MULTI-DIMENSIONAI CONTAMINANT TRANSPORT MODEL DEVELOPMENT

Authors

Leonard B. Collard

Gregory P. Flach

Westinghouse Savannah River Company Savannah River Site Aiken, SC 29808
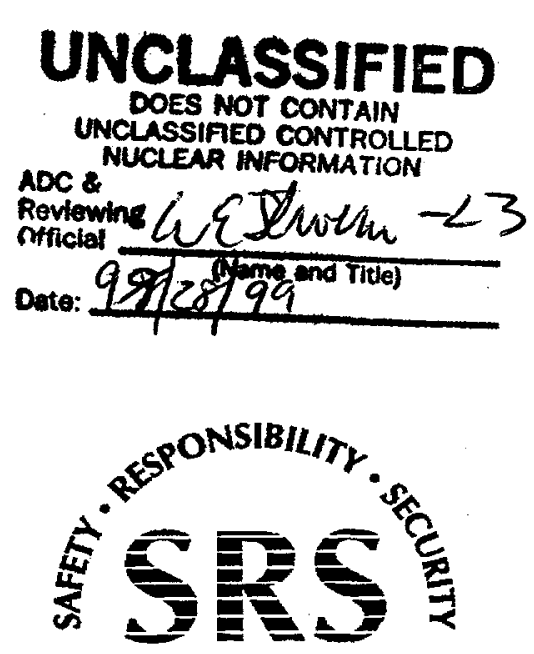
WSRC-TR-99-00100

September 24, 1999

HIGH-IEVEL WASTE TANKS

MULTI-DIMENSIONAL CONTAMINANT TRANSPORT MODEL DEVELOPMENT

Co-author

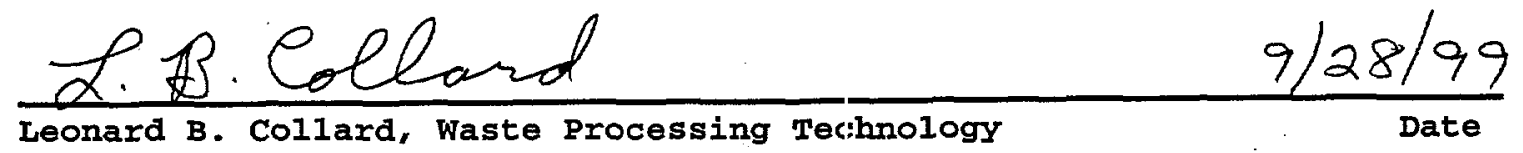

Co-author
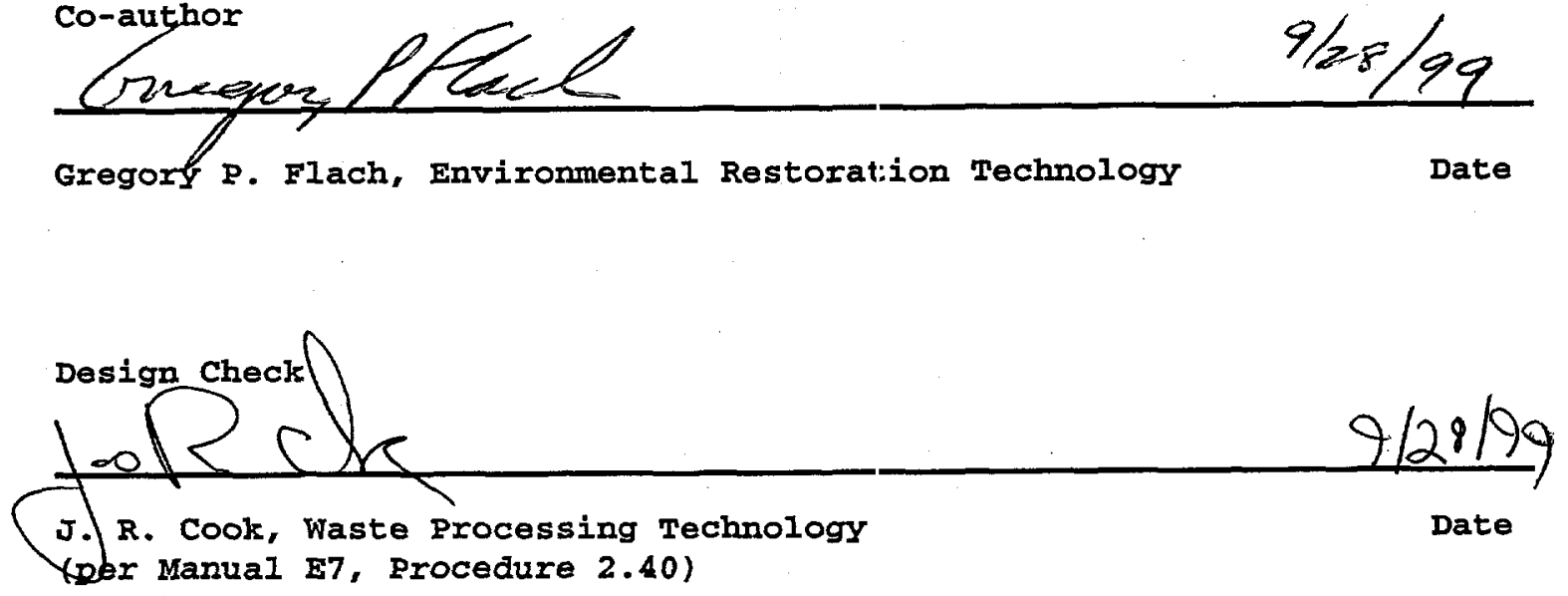

Approvals/Review

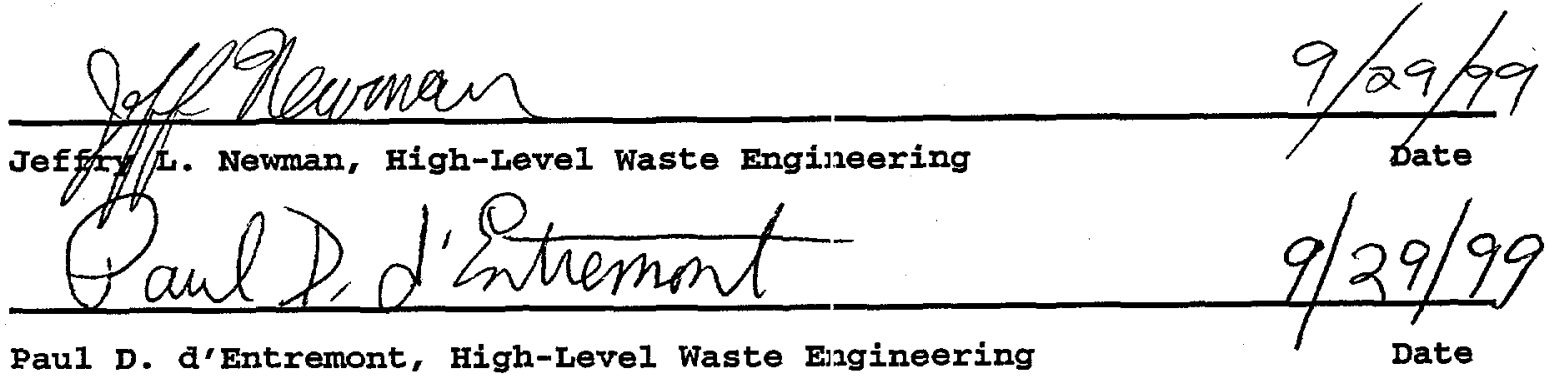

W.B. UanPect for B.T. Batedes 9/28/99

B.T. Butcher, Level 4 Manager, Waste Pricessing Technology

Date

ii 
LIST OF TABLES

EXECUTIVE SUMMARY ........................................................................................................................ VII

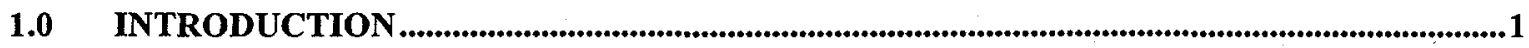

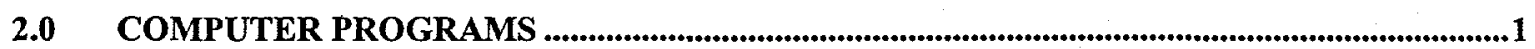

3.0 INFORMATION SOURCES

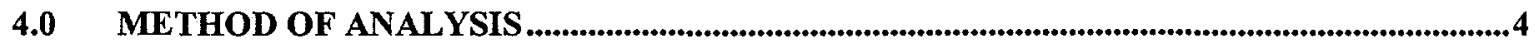

4.1 Contaminant Inventories and Decay Rates...................................................................6

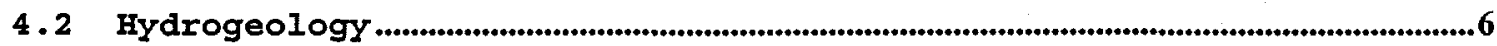

4.2.1 Ground-water Elevation with Respect to Tank Elevation ..................................................... 7

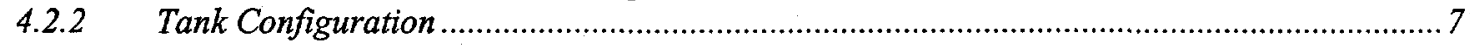

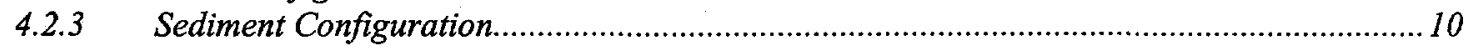

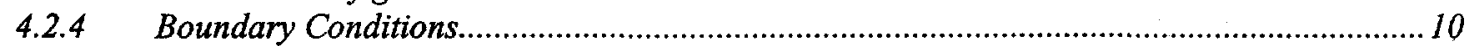

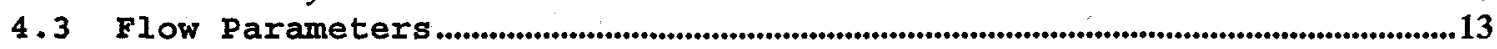

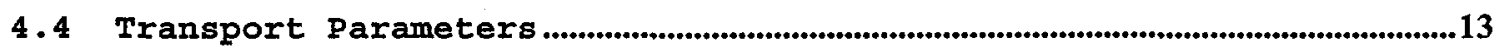

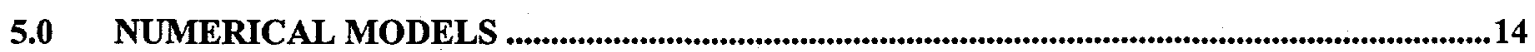

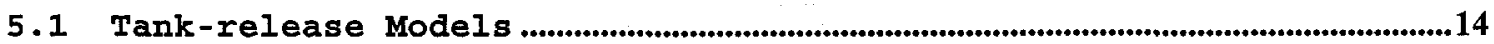

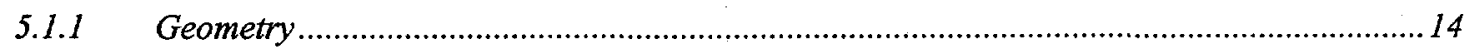

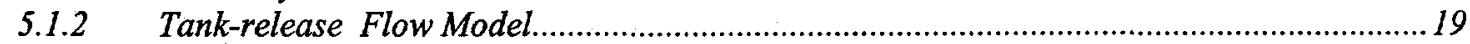

5.1.3 Tank-release Contaminant-Transport Model ....................................................................19

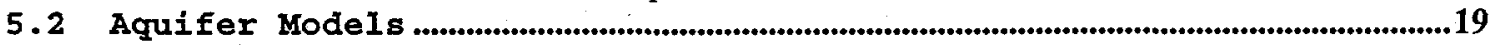

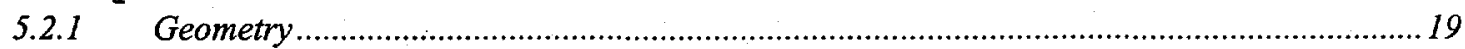

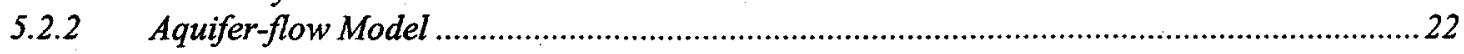

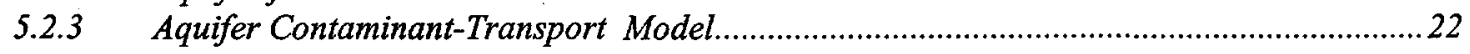

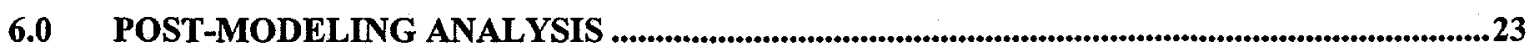

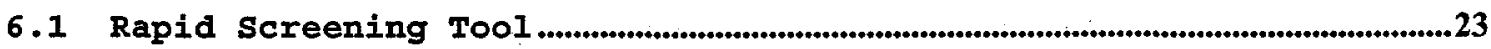

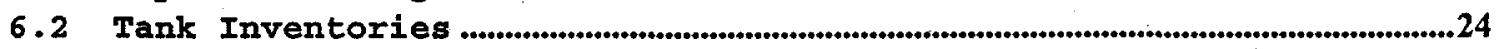

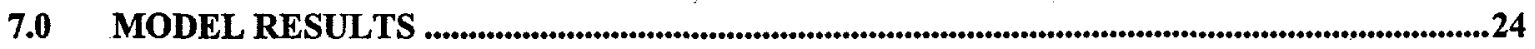

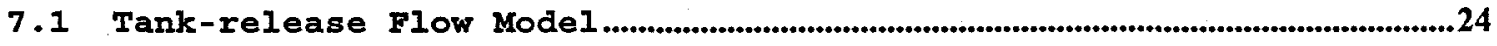

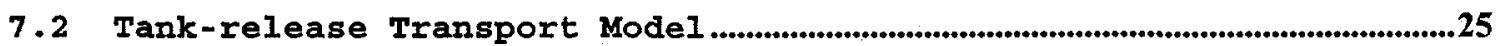

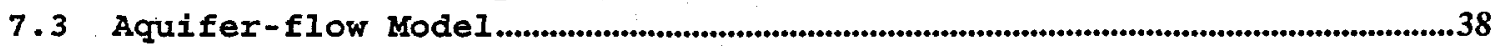

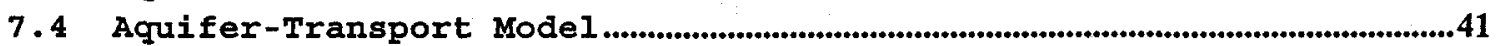

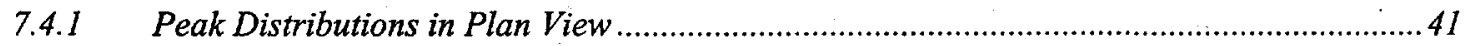

7.4.2 Histories for Seepline Cells with the Ten Highest-Peak Concentrations ............................... 49

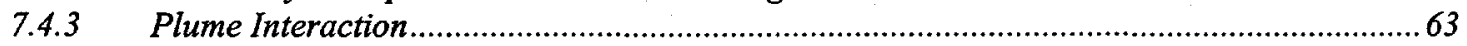

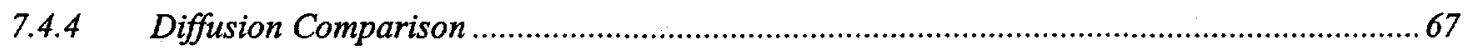

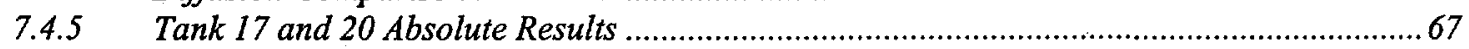

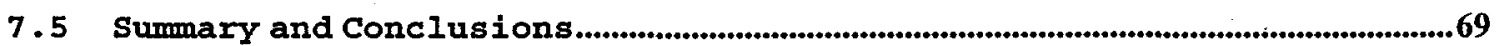

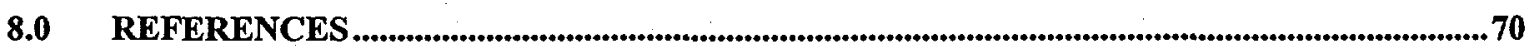

APPENDIX A 
Figure 1. Conceptual Model of Tank-Waste Contaminant Transport ...................................................2

Figure 2. Flowchart of Event Models......................................................................................................................5 5

Figure 3. Vertical Profile of Modeled Tank ................................................................................................. 9

Figure 4. Subdivision of Aquifer Cells to Generate Tank-release Model Cells........................................ 11

Figure 5. Tank Geometry for Water Table above Tank - Category 1 .................................................. 15

Figure 6. Tank Geometry for Water Table 2 Feet above Tank Floor - Category 2 .............................. 16

Figure 7. Tank Geometry for Water Table 1 Foot below Tank Base - Category 3.............................. 17

Figure 8. Tank Geometry for Water Table 10 Foot below Tank Base - Category 4............................. 18

Figure 9. Plan-view Mesh for F-Tank Farm ................................................................................................... 20

Figure 10. Plan-view Mesh for H-Tank Farm.......................................................................................21

Figure 11. Velocity Field for Tanks 9-12 below Water Table (Category 1) for Intact Case (first 1,000

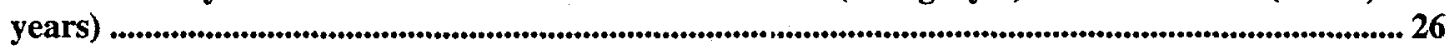

Figure 12. Velocity Field for Tanks 9-12 below Water Table (Category 1) for Failed Case (after 1,000

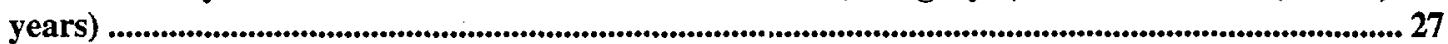

Figure 13. Velocity Field for Tanks 13-16 below Water Table (Category 2) for Intact Case (first 1,000

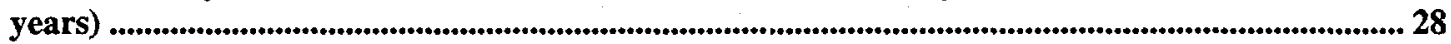

Figure 14. Velocity Field for Tanks 13-16 below Water Table (Category 2) for Failed Case (after

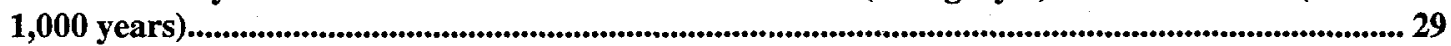

Figure 15. Velocity Field for Water Table 1 Foot below 'Tank Base (Category 3) for the "Intact" Case with 4 cm/yr Surface Flux............................................................................................................................... 30

Figure 16. Velocity Field for Water Table 1 Foot below 'Tank Base (Category 3) for the "Failed" Case

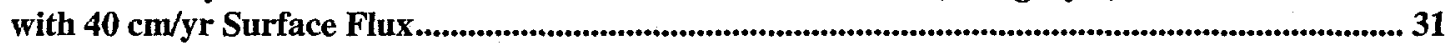

Figure 17. Velocity Field for Water Table 10 Feet below Tank Base (Category 4) for the "Intact"

Case with $4 \mathrm{~cm} / \mathrm{yr}$ Surface Flux......................................................................................................... 32

Figure 18. Velocity Field for Water Table 10 Feet below Tank Base (Category 4) for the "Failed"

Case with 40 cm/yr Surface Flux........................................................................................................... 33

Figure 19. Sum of Contaminant Fluxes to Aquifer for Each Tank with the Water Table above the Tank - Category 1

Figure 20. Sum of Contaminant Fluxes to Aquifer for F'ach Tank with the Water Table 1 Foot above the Waste - Category 2

Figure 21. Sum of Contaminant Fluxes to Aquifer for Fach Tank with One-Foot Thick Vadose Zone - Category 3

Figure 22. Sum of Contaminant Fluxes to Aquifer for Fach Tank with Ten Foot Thick Vadose Zone

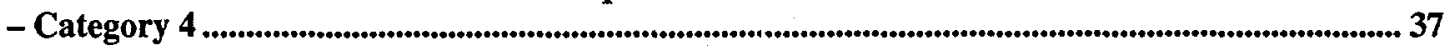

Figure 23. Streamlines from F-Farm Tanks to Seeplines................................................................................... 39

Figure 24. Streamlines from H-Farm Tanks to Seeplines........................................................................ 40

Figure 25A. Key for F-Farm Peak Concentrations in Plan View and Top Ten Peak Concentration Curves.

Figure 25B. Key for H-Farm Peak Concentrations in Plan View and Top Ten Peak Concentration

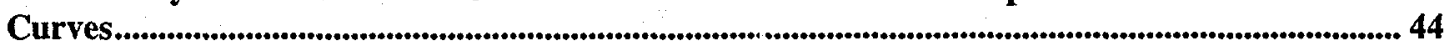

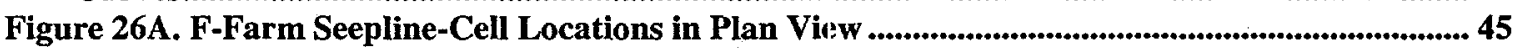

Figure 26B. H-Farm Seepline-Cell Locations in Plan View ................................................................ 45

Figure 27. Plan View of F-Farm Tc-99 Peak-Seepline Concentrations Based on Unit Ci Inventories

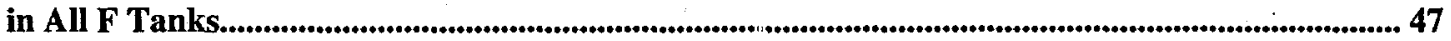

Figure 28. Plan View of F-Farm I-129 Peak-Seepline Concentrations Based on Unit Ci Inventories in

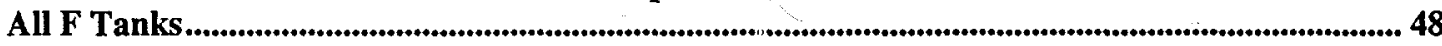

Figure 29. Plan View of H-Farm Tc-99 Peak-Seepline Concentrations Based on Unit Ci Inventories in All H Tanks.

Figure 30. Plan View of H-Farm I-129 Peak-Seepline Concentrations Based on Unit Ci Inventories in All $\mathrm{H}$ Tanks ...................................................................................................................................... 51

Figure 31. F-Farm Tc-99 Top-Ten Seepline-Concentration Curves Based on Unit Ci Inventories in All F Tanks. 
Figure 32. F-Farm Tc-99 Top-Ten Seepline-Concentration Curves Based on Unit Ci Inventories in Tank 17. 53

Figure 33. F-Farm Tc-99 Top-Ten Seepline-Concentration Curves Based on Unit Ci Inventories in Tank 20

Figure 34. F-Farm Tc-99 Top-Ten Seepline-Concentration Curves Based on Unit Ci Inventories in

Tanks 17 and 20

Figure 35. F-Farm Tc-99 Top-Ten Seepline-Concentration Curves Based on Unit Ci Inventories in

Tanks 17-20.

Figure 36. H-Farm Tc-99 Top-Ten Seepline-Concentration Curves Based on Unit Ci Inventories in

All H Tanks

Figure 37. H-Farm Tc-99 Top-Ten Seepline-Concentration Curves Based on Unit Ci Inventories in

Tanks 13-16.

Figure 38. F-Farm I-129 Top-Ten Seepline-Concentration Curves Based on Unit Ci Inventories in

All F Tanks

Figure 39. F-Farm I-129 Top-Ten Seepline-Concentration Curves Based on Unit Ci Inventories in

Tanks 17-20

Figure 40. H-Farm I-129 Top-Ten Seepline-Concentration Curves Based on Unit Ci Inventories in

All H Tanks

Figure 41. F-Farm Tc-99 Plume Interaction for Tanks 17-20 vs. Entire Farm .................................. 64

Figure 42. F-Farm I-129 Plume Interaction for Tanks 17-20 vs. Entire Farm 65

Figure 43. H-Farm Tc-99 Plume Interaction for Tanks 13-16 vs. Entire Farm .66

Figure 44. Diffusion Comparison for Dual Load of Tanks 17 and 20 vs. Sum of Individual Loads .. 68 
Table 1. Elevations and Vadose-Zone Thickness................................................................................................... 8

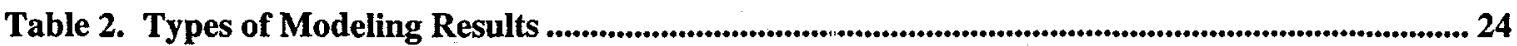

Table 3. Tank-Load Combinations and Purposes .............................................................................4 41

Table 4. Plan Views of Peak Concentrations................................................................................................42 42

Table 5. Plume-Interaction Plots..................................................................................................................6 63

Table 6. Absolute Tc-99 Results for Tanks 17 and 20 and Previous One-Dimensional Modeling

Results

Table A-1. Radionuclide Half-Lives. 71

Table A-2. Flow Parameters for Vadose Zone Models................................................................................ 71

Table A-3. Transport Parameters for Vadose Zone Models......................................................................... 71

Table A-4. Distribution Coefficients for Vadose Zone Models (m//g) ....................................................... 71

Table A-5. Transport Parameters for Aquifer Models ..................................................................................... 71 


\section{EXECUTIVE SUMMARY}

A suite of multi-dimensional computer models was developed to analyze the transport of residual contamination from high-level waste tanks through the subsurface to seeplines. Cases analyzed ranged from all the tanks in the $\mathrm{F}$ - and $\mathrm{H}$-tank farms for an overall look; to the Tank 17-20 4-pack to study plume interaction; to individual tanks, such as Tank 17 and 20 for comparison with one-dimensional modeling. These models could form the basis for future tank closure analyses and for implementing an innovative rapid screening approach that uses a database of influence curves generated from individual tank models.

Models were developed to analyze the release of contaminants from tanks and their transport to the aquifer (see Figure 1). Subsequent models were developed to analyze contaminant transport through the aquifer to seeplines. Release of contaminants from tanks was modeled on a tankby-tank basis. Each tank model generated a contaminant flux to the aquifer, i.e. an aquifer contaminant load. Contaminant transport through the aquifer was modeled by analyzing the aquifer loads from one or more tanks, as desired, in a single multi-aquifer model. Several tank combinations were modeled in order to examine the effects of plume interaction from multiple tank sources.

Al1 1,318 locations in the model domain that discharged to creeks were identified as seepline cells. A preliminary database was developed containing concentrations for the modeled contaminants. Concentrations were recorded every two years up to 10,000 years.

Table $i$ compares results of this multi-dimensional work for Tc-99 with results from a one-dimensional model used to develop dose estimates for the Tank 17 and Tank 20 Closure Modules. Table $i$ indicates that the ratio of tank inventories for Tank 17 to Tank 20 (64.7:1) is comparable to the ratio of the multi-dimensional model peak doses $(65.5: 1)$, but that it is different than the ratio of the one-dimensional model peak doses $(4.6: 1)$.

Table i. Multi-dimensional Model Tc-99 Results for Tanks 17 and 20 Compared to One-Dimensional Closure Module Results

\begin{tabular}{|c|c|c|c|c|c|}
\hline & & \multicolumn{3}{|c|}{ Multi-dimensional Model } & \multicolumn{2}{|c|}{ One-dimensional Model } \\
\hline Tank Id & $\begin{array}{c}\text { Tc-99 Inventory } \\
\mathrm{Ci}\end{array}$ & $\begin{array}{c}\text { Peak Dose } \\
\text { Mrem/yr }\end{array}$ & $\begin{array}{c}\text { Peak Time } \\
\text { Years }\end{array}$ & $\begin{array}{c}\text { Peak Dose } \\
\text { Mrem/yr }\end{array}$ & $\begin{array}{c}\text { Peak Time } \\
\text { Years }\end{array}$ \\
\hline 17 & $3.58 \mathrm{E} 0$ & $5.62 \mathrm{E}-03$ & 2326 & $6.00 \mathrm{E}-02$ & 1855 \\
\hline 20 & $5.53 \mathrm{E}-2$ & $8.58 \mathrm{E}-05$ & 2342 & $1.30 \mathrm{E}-02$ & 1855 \\
\hline
\end{tabular}

Peak concentration times are similar for both tanks in the multidimensional model - about 2300 years. Peak concentration times are identical for both tanks in the one-dimensional model - about 1,800 years, about 500 years before the multi-dimensional model peaks.

Doses from the multi-dimensional modeling are less than the doses calculated from the one-dimensional Closure Module modeling in both cases. For Tank 17 the difference is one order of magnitude and for Tank 20 the difference is about three orders of magnitude. 


\subsection{INTRODUCTION}

A suite of multi-dimensional computer models was developed to analyze the transport of residual contamination from high-level waste tanks through the subsurface to seeplines. These models could form the basis for future tank closure analyses and for implementing an innovative, rapid screening approach that uses a database of influence curves generated from individual tank models.

Models were developed to analyze the reiease of contaminants from tanks and their transport to the aquifer (see Figure 1). Subsequent models were developed to analyze contaminant transport through the aquifer to seeplines. Release of contaminants fron tanks was modeled on a tankby-tank basis. Each tank model generated a contaminant flux to the aquifer, i.e. an aquifer contaminant load. Contaminant transport through the aquifer was modeled by analyzing the aquifer loads from one or more tanks, as desired, in a single nulti-aquifer model. Several tank combinations were modeled to examine the effects of plume interaction from multiple tank sources.

All locations within the model domain that discharged to creeks were identified as seepline cells. A preliminary database was developed containing concentrations for the modeled contaminants at more than 1,000 seepline cells. Concentrations were recorded every two years of the simulation period, up to 10,000 years.

The main purpose of this work was to develop and test the models, so only two relatively conservative contaminants were examined, Tc-99 and I-129. More complex analyses, such as solubility-limited species and radionuclides that head a decay chain were not addressed in this study.

\subsection{COMPUTER PROGRAMS}

Computer programs were used to predict water flow and contaminant transport through the subsurface. The ?ORFLOWC (ACRi, 1998) program predicted ground-water flow and contaminant transport through the vadose zone for the tank-release model. For the aquifer-system model, the FACT program predicted water flow and the PORFLOW program predicted contaminant transport.

The FACT and PORFLOW computer programs are similar in their general capabilities. However, FACT is a finite-element program while PORFLOW is a finite-difference program, so transferring data between the programs requires extra care and effort.

PORFLOW was selected to model all the contaminant-transport cases, because it handles radioactive daughters better than FACT does. For ease of data transfer PORFLOW was used to model water flow in the vadose zone. FACT was selected to model water flow in the aquifer, because FACT had already been used to model the entire GSA and considerable savings were realized by taking advantage of that previous work. 
WSRC-TR-99-00100

September 24, 1999

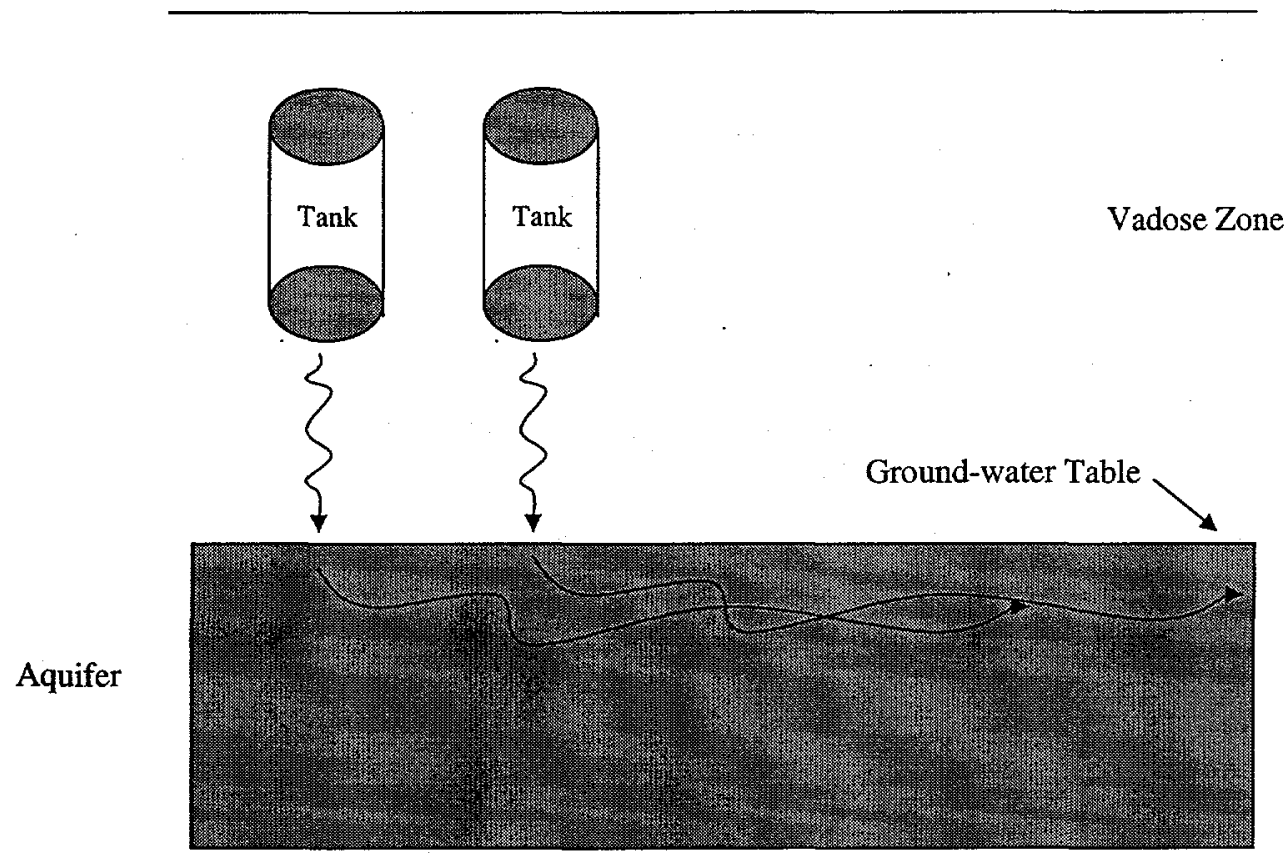

Figure 1. Conceptual Model of Tank-Waste Contaminant Transport 
The FACT program is numerical-analysis software for modeling groundwater flow and contaminant transport. Harlier work by SRTC for Environmental Restoration created a highly detailed site-specific FACT aquifer-flow model that incorporated "37,500 lithology data records" and "approximately 481 slug tests, 85 single and multiple well pumping tests, and 258 laboratory permeability neasurements" (Flach and Harris, 1999). Two subsets of the calibrated FACT model were used in the present models, one subset for the F-tank farm and one for the H-tank farm.

The PORFLOW program is numerical-analysis software for modeling groundwater flow and contaminant transport through the subsurface. PORFLOW can accommodate multiple chemical species, radioactive-decay chains, transient and steady-state flow conditions, saturated and unsaturated media, multiple material types, and one--, two- or three-dimensional geometries of any shape. State and federal regulators throughout the United states have accepted PORFLOW results for similar applications (Collard, 1998).

\subsection{INFORMATION SOURCES}

Ground-water flow models required the following information:

- Hydrogeology including natural and man-made features

- Elevation of water table relative to the inside tank floor

- Geometry

- Tank configuration

- Sediment configuration

- Boundary conditions

- Ground-water flow parameters for each material type.

Contaminant-transport models required the following information:

- Contaminant inventories and clecay rates for each contaminant

- Geometry from the ground-water flow model

- Tank configuration

- Sediment configuration

- Boundary conditions

- Contaminant-transport parameters for each material type

- Volumetric water fluxes and saturations from the groundwater flow model.

Model input values for parameters are presented in tables in Appendix A and are described in Sections 4.1 throuch 4.4 .

Hydrogeologic information was gleaned from many sources. Water-table elevation data were selected from the GJMS on-line database.

Engineering drawings were examined to determine the elevations and configurations of tanks. Ground-water flow properties were obtained from the Tank 20 analysis (DOE, 1997a), the Composite Analysis (DOE, 1997b), the F- and H-Area closure plan (DOE, 1996), the GSA flow 
modeling study (Flach and Harris, 1999) and Freeze and Cherry (1979). Boundary conditions were based on symmetry, recharge rates from the Tank 20 Analysis (DOE, 1997a), physical conditions at the water table, and from the GSA flow modeling study (Flach and Harris, 1999).

Contaminant inventories were modeled as unity for each contaminant in each tank. Contaminant decay rates were selected from previous studies. Contaminant-transport properties were obtained from the Tank 20 analysis (DOE, 1997a). Contaminant boundary conditions were established based on the physical setting.

\subsection{METHOD OF ANALYSIS}

The first step in the analysis was to define event conceptual models. The event conceptual models (see Figure 2) can be depicted as follows:

1. Tank-Release Model

- Ground-water flow through a tank to the aquifer

- Contaminant transport through a tank to the aquifer

2. Aquifer Model

- Ground-water flow through the aquifer to the seepline

- Contaminant transport through the aquifer to the seepline.

Ground-water flow is analyzed to establish a steady-state flow field, i.e. a flow regime that does not change with respect to time. This flow field is then used to analyze contaminant movement with respect to time.

The first transport event is the contaminant release from the tank and movement outside the tank to the aquifer. The second transport event is the movement of the contaminant through the aquifer to the seepline.

For the ground-water flow in the tank-release model, two steady-state flow fields are established. The first flow field represents the case when the tank and cover materials are assumed to be intact, resulting in low flows through the tank. This "intact-state" flow field is assumed to exist for the first 1,000 years. The second flow field represents the case when the tank and cover materials are assumed to have failed and metamorphosed to the surrounding materials. This "failed-state" flow field is assumed to exist after the first 1,000 years for the duration of the simulation.

In the tank-release model, four tank-release categories were considered as follows:

- Tank-release Category 1:

- Tank-release Category 2:

- Tank-release Category 3:

- Tank-release Category 4:
Ground-water table is above the tank top

Ground-water table is two feet above the inside tank floor Ground-water table is one foot below the outside tank base Ground-water table is ten feet below the outside tank base. 
Tank-release Models

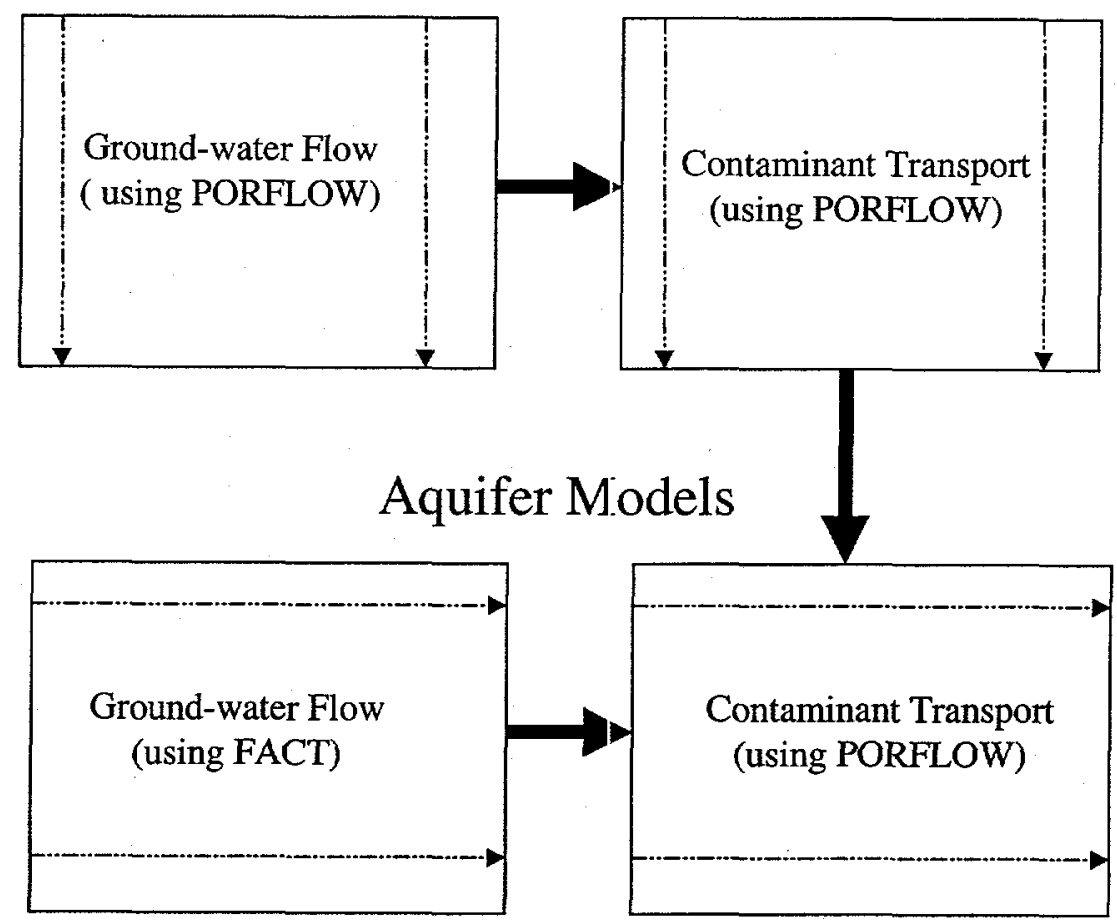

Figure 2. Flowchart of Event Models 
Each tank was assigned to one of the categories above, based on the ground-water table elevation relative to the inside tank-floor elevation, as discussed in Section 4.2.1.

The event conceptual models were transformed into numerical models by describing the geometry of the modeling domain and by assigning values for all input data. Input data can be classified as follows:

1) Inventories for Radionuclides of Concern and Decay Rates

2) Hydrogeology (including boundary conditions)

3) Flow Parameters

4) Transport Parameters

5) Actual Tank Inventories.

The first four classes of data are discussed in sections 4.1 through 4.4. Actual tank inventories are addressed in the post-modeling analysis provided in section 6 .

For each conceptual model, input parameters were assigned to generate a numerical model, as discussed in section 5. After the numerical model was generated, the appropriate computer program was executed to analyze the model.

After each numerical model was executed, post-modeling analysis was performed to calculate final results. Post-modeling analyses are discussed in section 6.

\subsection{Contaminant Inventories and Decay Rates}

The conceptual model for contaminant release from the tanks considered an inventory of a single curie in a tank, in order to provide a fractional basis for post-modeling analysis. Tank-release model results are the aquifer model contaminant loads that are expressed as fractional fluxes to the aquifer, i.e., relative to the tank's unitcurie inventory.

For multiple-tank analyses, each tank was assigned a unit-curie inventory. Results for such models are no longer true fractional results, but are the sum of each individual tank's fractional contribution. Results from individual-tank models and tank-farm models can be combined to generate a rapid-screening approach that is discussed in section 6.

The radioactive-decay rate is input in the form of a half-life. The half-lives for TC-99 and I-129 are presented in Table A.1.

\subsection{Hydrogeology}

The hydrogeology includes the configuration and properties of subsurface materials and applicable boundary conditions. This section discusses the configuration and the boundary conditions, while the values of the properties are discussed in subsequent sections. The configuration is subdivided as follows: 
- Ground-water elevation with respect to tank elevation

- Tank configuration

- Sediment configuration.

\subsection{Ground-water Elevation with Respect to Tank Ele`ation}

The GIMS database and engineering drawirgs were examined for each highlevel waste tank. Table 1 shows the inside-floor elevation for each tank, the ten-year average water-table ellevation, the calculated thickness of the vadose zone and the assigned tank-release category (see section 4.0).. The inside-floor elevation is the lowest location for storing waste materials, rather than the base of the tank.

Table 1 shows eight tanks with a negative vadose-zone thickness. This indicates that the ground-water table is above the inside-floor elevation.

\subsubsection{Tank Configuration}

The modeled-tank configuration is a vertical profile projected onto a two-dimensional vertical plane (see Figure 3). In ascending order, the tank consists of the base, residual waste mixed with reducing grout, grout added to fill the tank prior to closing, and the roof.

Laterally, the tank consists of the outside walls, the annulus and the center or container portion of the tank. The outside diameter of the tank is ninety-five feet in the model. The differences between the types of tanks were not explicitly mode-.ed, rather, a generic-tank model was developed.

This initial approach is adequate for most tanks, because the key elements of the configuration do not vajy significantly. The Tank-20 closure-modeling report (DOE, 1997a) discussed the importance of the basemat and the vadose-zone thickness in its Uncertainty/sensitivity Analysis. The basemat thickness for the various tank types is as follows:

$\begin{array}{ll}\text { Tank Type } & \text { Basemat Thickness (ft) } \\ \text { I } & 3.0 \\ \text { II } & 3.5 \\ \text { III } & 4.0 \\ \text { IV } & 0.58\end{array}$

Tank Types I through III are similar with an average basemat thickness of 3.5 feet. However, tank Type IV has a basemat thickness of only 0.58 feet. The initial modeling considered all tanks to have a basemat thickness of 3.5. A special analysis was made for the case of comparing results with the one-dimensional modeling results where the basemat thickness was set to 0.58 feet. Concentrations essentially doubled and the peak times were reduced by two-thirds when the basemat thickness was reduced, so future models should incorporate the more appropriate basemat thickness of 0.58 feet for Type IV tanks (i.e., Tanks 17 through 24). This special analysis is identical to other models except for the basemat thickness, so it is not discussed further - only the results are discussed in section 7.4.5. 


\begin{tabular}{|c|c|c|c|c|c|}
\hline Tank ID & Farm & Tank Floor & Water Table & Vadose Zone (ft) & Release Category \\
\hline 1 & $F$ & 244.36 & 224.82 & 19.54 & 4 \\
\hline 2 & $\mathrm{~F}$ & 244.36 & 224.82 & 19.54 & 4 \\
\hline 3 & $\mathrm{~F}$ & 242.94 & 224.72 & 18.22 & 4 \\
\hline 4 & $F$ & 242.94 & 224.90 & 18.04 & 4 \\
\hline 5 & $\mathrm{~F}$ & 241.52 & 224.84 & 16.68 & 4 \\
\hline 6 & $F$ & 241.52 & 224.41 & 17.11 & 4 \\
\hline 7 & $F$ & 240.10 & 224.22 & 15.88 & 4 \\
\hline 8 & $\mathbf{F}$ & 240.10 & 224.22 & 15.88 & 4 \\
\hline 9 & $\mathrm{H}$ & 244.39 & 272.69 & -28.30 & 1 \\
\hline 10 & $\mathrm{H}$ & 244.39 & 273.86 & -29.47 & 1 \\
\hline 11 & $\dot{\mathrm{H}}$ & 242.89 & 273.58 & -30.69 & 1 \\
\hline 12 & $\mathrm{H}$ & 242.89 & 274.70 & -31.81 & 1 \\
\hline 13 & $\mathrm{H}$ & 274.08 & 275.72 & -1.64 & 2 \\
\hline 14 & $\mathrm{H}$ & 274.08 & 276.30 & -2.22 & 2 \\
\hline 15 & $\mathrm{H}$ & 274.08 & 275.40 & -1.32 & 2 \\
\hline 16 & $\mathrm{H}$ & 274.08 & 276.29 & -2.21 & 2 \\
\hline 17 & $F$ & 228.89 & 223.92 & 4.97 & 3 \\
\hline 18 & $F$ & 228.89 & 224.00 & 4.89 & 3 \\
\hline 19 & $F$ & 227.97 & 223.76 & 4.21 & 3 \\
\hline 20 & $F$ & 227.97 & 224.70 & 3.27 & 3 \\
\hline 21 & $\mathrm{H}$ & 282.03 & 274.04 & 7.99 & 3 \\
\hline 22 & $\mathrm{H}$ & 282.03 & 273.50 & 8.53 & 3 \\
\hline 23 & $\mathrm{H}$ & 282.03 & 273.97 & 8.06 & 3 \\
\hline 24 & $\mathrm{H}$ & 282.03 & 273.52 & 8.51 & 3 \\
\hline 25 & $\mathrm{~F}$ & 248.53 & 223.20 & 25.33 & 4 \\
\hline 26 & $F$ & 249.88 & 223.25 & 26.63 & 4 \\
\hline 27 & $F$ & 249.88 & 223.29 & 26.59 & 4 \\
\hline 28 & $\mathrm{~F}$ & 248.53 & 223.35 & 25.18 & 4 \\
\hline 29 & $\mathrm{H}$ & 287.66 & 273.74 & 13.92 & 4 \\
\hline 30 & $\mathrm{H}$ & 286.66 & 273.73 & 12.93 & 4 \\
\hline 31 & $\mathrm{H}$ & 285.66 & 273.18 & 12.48 & 4 \\
\hline 32 & $\mathrm{H}$ & 284.16 & 273.72 & 10.44 & 4 \\
\hline 33 & $\mathrm{~F}$ & 248.16 & 224.67 & 23.49 & 4 \\
\hline 34 & $F$ & 248.16 & 225.39 & 22.77 & 4 \\
\hline 35 & $\mathrm{H}$ & 286.92 & 270.50 & 16.42 & 4 \\
\hline 36 & $\mathrm{H}$ & 287.92 & 269.15 & 18.77 & 4 \\
\hline 37 & $\mathrm{H}$ & 287.92 & 268.91 & 19.01 & 4 \\
\hline 38 & $\mathrm{H}$ & 295.34 & 275.70 & 19.64 & 4 \\
\hline 39 & $\mathrm{H}$ & 296.34 & 275.40 & 20.94 & 4 \\
\hline 40 & $\mathrm{H}$ & 296.34 & 275.75 & 20.59 & 4 \\
\hline 41 & $\mathrm{H}$ & 295.34 & 275.46 & 19.88 & 4 \\
\hline 42 & $\mathrm{H}$ & 297.34 & 275.75 & 21.59 & 4 \\
\hline 43 & $\mathrm{H}$ & 297.34 & 275.07 & 22.27 & 4 \\
\hline 44 & $F$ & 248.21 & 223.46 & 24.75 & 4 \\
\hline 45 & $F$ & 249.64 & 222.74 & 26.90 & 4 \\
\hline 46 & $F$ & 249.64 & 222.78 & 26.86 & 4 \\
\hline 47 & $F$ & 248.21 & 222.86 & 25.35 & 4 \\
\hline 48 & $\mathrm{H}$ & 292.39 & 276.00 & 16.39 & 4 \\
\hline 49 & $\mathrm{H}$ & 292.39 & 275.44 & 16.95 & 4 \\
\hline 50 & $\mathrm{H}$ & 289.89 & 275.70 & 14.19 & 4 \\
\hline 51 & $\mathrm{H}$ & 289.89 & 275.69 & 14.20 & 4 \\
\hline
\end{tabular}

\footnotetext{
${ }^{1}$ Based on GIMS database and engineering drawings. Elevations are feet Above Mean Sea Level.
} 


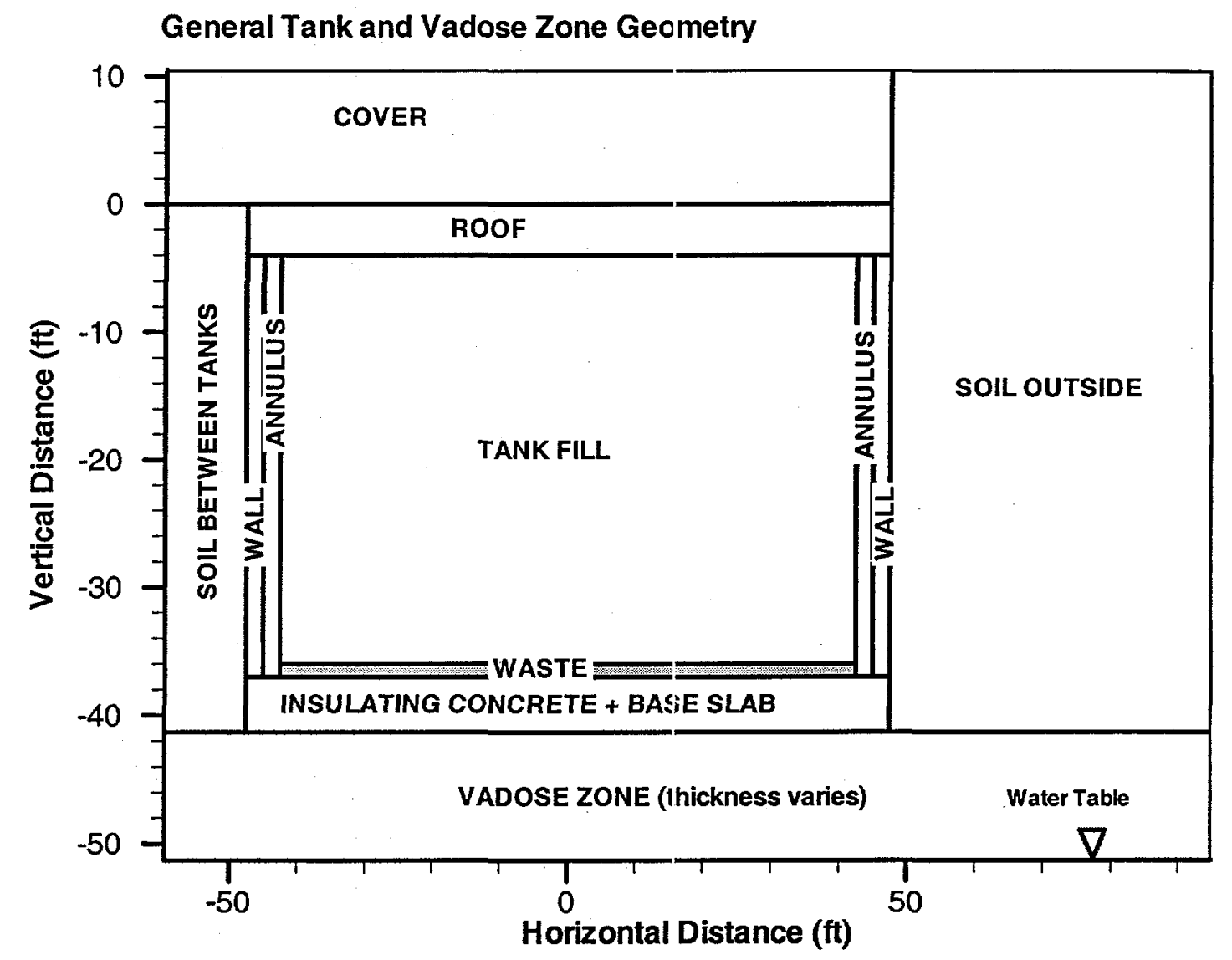

Figure 3. Vertical Profile of Modeled giank 
Tank configurations were identical except for Tanks 13-16. Those tanks were truncated at the ground-water table, about two feet above the inside floor, as described in section 5.

\subsubsection{Sediment Configuration}

For the contaminant-release models (both flow and transport), sediment surrounding the tank was represented by the "native soil" from the Composite Analysis (DOE, 1997b) and the E-Area low-level waste performance assessment (DOE, 1998). The "native soil" is a hybrid formed by combining measured backfill-soil properties and topsoil properties (see Yu, et. al, 1993 for measured values).

For the aquifer-flow model, each cell in the modeling domain was considered to be a unique material, based on 37,500 lithology data records and other data. For the aquifer-transport model, cells were assigned either sand or clay transport properties. Sediments were assigned clay properties only if the vertical hydraulic conductivity from the aquifer ground-water flow model was less than $1 . E-7 \mathrm{~cm} / \mathrm{sec}$. Thus, parts of the layers typically described as the "tan clay" or the "green clay" (Flach and Harris, 1999), were assigned sand transport properties based on the vertical hydraulic conductivity.

\subsubsection{Boundary Conditions}

Boundary conditions are prescribed separately for ground-water flow and contaminant-transport problems. Specific input values are described in the bulleted sections below.

\section{- Tank-release Flow Model}

For flow models representing the first and second tank-release categories, only the saturated zone was modeled. For these flow models all model-domain boundary conditions were prescribed using Darcy velocities derived from the aquifer-flow-model volumetric flux.

Darcy velocities are calculated by dividing the volumetric flux by the cross-sectional area that the flux crosses, thus generating a volumetric flux per unit area. The two-dimensional flow model was developed so that horizontal flow entered from the left-hand side and exited on the right-hand side. The sum of all horizontal volumetric influxes from the aquifer model was used to calculate the Darcy velocity for the left-hand side of the tank-release model.

Meanwhile, the sum of all horizontal volumetric fluxes out of the aquifer-model cell was used to calculate the Darcy velocity for the right-hand side of the tank-release model. The Darcy velocities at the top and base of the tank-release model domain were both downward.

For these two categories, tank-release model cells were developed vertically by subdividing the upper portion of the aquifer model in the " $Z$ " direction (see Figure 4), such that no tank-release cell vertically straddled an aquifer cell. The tank-release model cells were sized horizontally, such that the tank approximated the aquifer cell width. Material was added to each tank side, so that boundary conditions would not be applied directly to the tank. 


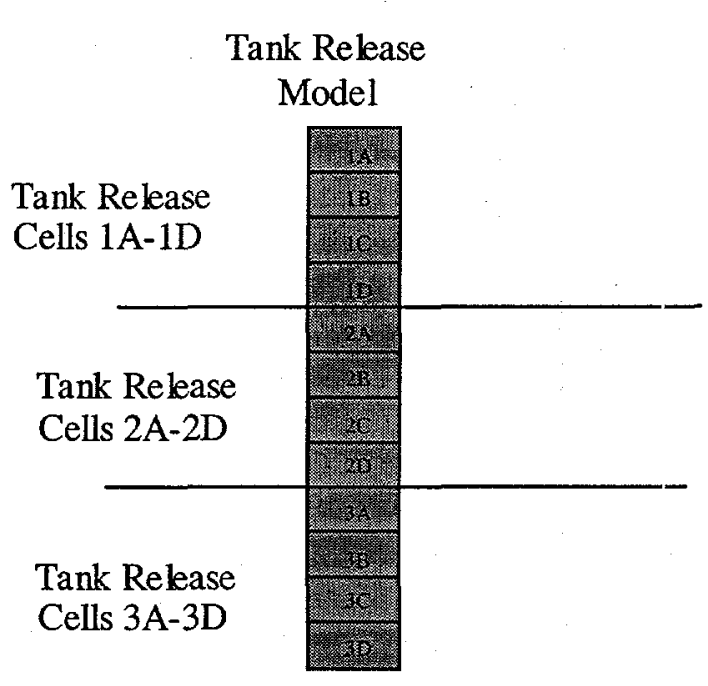

Aquifer Model - 1

column

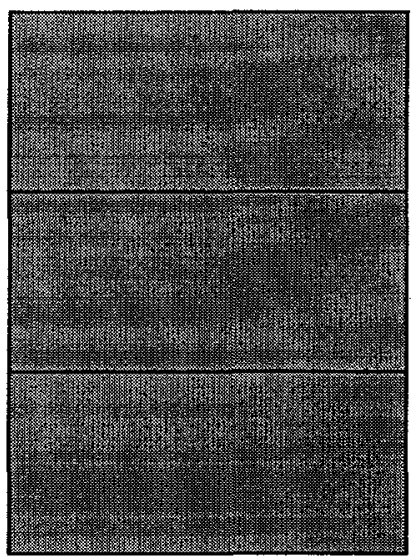

Aquifer

Cell 1

Aquifer

Cell 2

Aquifer

Cell 3

Figure 4. Subdivision of Aquifer Cells to Generate Tank-release Model Cells 
For the second tank-release category an artificial cap was placed over a truncated, saturated tank (see section 5.1). The side-boundary conditions for this additional material were assigned by duplicating the Darcy velocities imposed on the tank cell immediately below the cap.

For the flow models representing the third and fourth tank-release categories, modeling-domain boundary conditions were prescribed as follows :

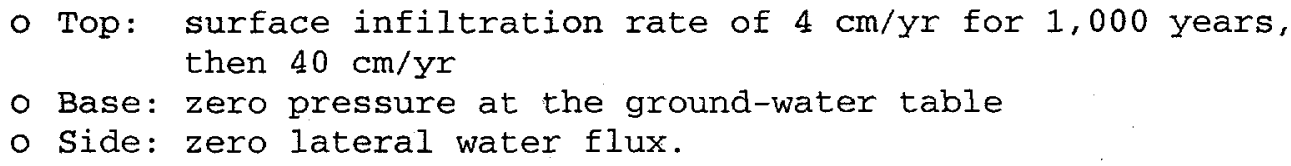

The top condition of $4 \mathrm{~cm} / \mathrm{yr}$ surface infiltration was used to develop the first or "intact-state" steady-state flow field. The top condition of $40 \mathrm{~cm} / \mathrm{yr}$ surface infiltration was used to develop the second or "failed-state" steady-state flow field.

The side-boundary conditions force all water to enter at the top and exit at the bottom. The base-boundary condition represents a static water table.

\section{- Tank-release Contaminant-Transport Model}

For the contaminant-transport models representing the first and second tank-release categories (saturated zone only), diffusion out of the model domain was not permitted for the left or the top edges, where water entered the modeling domain. Along the right and bottom edges, the concentration was set to zero. This condition maximizes the flux of contaminant out of the modeling domain caused by diffusion. However, it represents a tradeoff, because the flux of contaminant out of the modeling domain caused by advection is reduced. Increasing the contaminant fluxes loading the aquifer increases the concentrations at the seepline.

For the contaminant-transport models representing the third and fourth tank-release categories (full vadose zone), diffusion out of the model domain was not permitted at any of the edges. The direction of water travel is primarily downward. Prohibiting diffusion out the sides constrains the contaminants to exit the model at the base. Prohibiting diffusion out the base of the modeling domain increases the amount of contamination that exits the modeling domain via advection. A zero concentration at the top of the water table is not warranted, because the water table will rise and fall over time (although this action is not modeled), and the concentrations at the top of the aquifer will not be zero all the time.

\section{- Aquifer-flow Model}

As discussed earlier, Flach and Harris (1999) developed the aquiferflow model. Their boundary conditions consisted of surface infiltration or surface discharge into creeks at the top, constant 
pressure heads or zero flux along the sides and leakance at the base. Details are provided in their report (Flach and Harris, 1999).

\section{- Aquifer Contaminant-Transport Model}

For the contaminant-transport models, diffusion out of the model domain was prohibited for all edges. For the aquifer model, advection will dominate and diffusion should play a very minor role, so the choice in boundary condition for transport is of little importance. With no diffusion allowed, concentrations within the modeling domain will slightly increase, leading to slightly nore conservative results.

\subsection{Flow Parameters}

\section{- Tank-release Flow Model}

Flow parameters for the tank-release model were based on information from the Tank 20 analysis (DOE, 1997a), the Composite Analysis (DOE, 1997b), the F- and H-Area closure plan (DOE, 1996), and Freeze and Cherry (1979). Flow parameters were assigned for two periods - the intact state through 1,000 years and the failed state after 1,000 years.

Flow parameters are presented in Table 1.2 . Flow parameters include dry bulk density, vertical and horizontal hydraulic conductivities, and effective porosity.

The porosity and density for the tank and waste were assigned the average of the intact and failed states to preserve contaminant mass balance. A better approximation could be obtained by making two separate PORFLOW runs and writing an auriliary program to calculate the contaminant split between the soil and the liquid for both states. This more rigorous approach was not pursued, because of the following:

(a) Model results are not expected to be highly sensitive to changes in porosity and density.

(b) The concrete is likely to fail by cracking followed by adjacent material filling the cracks, rather than by a complete disappearance of the concrete. The porosity and density of the filled concrete will more closely approximate the average of the concrete and the adjacent material, than being equal to the adjacent material.

- Aquifer-flow Model

Flow parameters for the aquifer-flow moclel are described in Flach and Harris (1999).

\subsection{Transport Parameters}

\section{- Tank-release Contaminant-Transport Model}

Contaminant-transport parameters for the tank-release model were based on information from the Tank 20 analysis; (DOE, 1997a), the Composite 
Analysis (DOE, 1997b), the F- and H-Area closure plan (DOE, 1996), and Freeze and Cherry (1979). The same contaminant-transport parameters were assigned for both the intact state through 1,000 years and the failed state after 1,000 years, because they primarily would be affected by chemical changes, not by physical changes.

Transport parameters are presented in Table A.3. Transport parameters included in those tables are dry bulk density, molecular diffusion, and mechanical dispersion and total porosity.

Inventories and decay rates affecting the fate and transport of contaminants are discussed in section 4.1. The distribution coefficient is a contaminant-specific property that describes the partitioning of the contaminant between the solids and the water. Distribution coefficients $\left(K_{d} S\right)$ are presented in Table A.4.

\section{- Aquifer Contaminant-Transport Mode1}

Transport parameters for the aquifer were based on the Tank 20 analysis parameters. As discussed in section 4.2.3, only sand or clay materials were used in the model. Transport parameters for the aquifer contaminant-transport model are presented in Table A.5. The distribution coefficients $\left(\mathrm{K}_{\mathrm{d}} \mathrm{S}\right)$ and half-lives are included in Table A.5 with the tank-release transport model values.

\subsection{NUMERICAL MODELS}

Numerical models are developed from conceptual models. A discretization of the model domain produces a mesh of individual cells that represents the geometries. Each individual cell is assigned flow or transport parameters and boundary conditions are applied to the edges of the model domain to complete the numerical models. For the transport models, some results from the flow models are also required as inputs.

\subsection{Tank-release Models}

Because two steady-state flow fields are required for each of the four categories of tank-release models, eight numerical flow models were required. Each numerical transport model incorporates volumetric water fluxes from both the "intact state" and "failed state," hence only four numerical transport models were required, one for each tank-release category.

\subsubsection{Geometry}

For each tank-release category, its flow and transport meshes for numerical models are identical, because the geometries do not change. Meshes for the four categories are shown in Figures 5 through 8.

Tanks 13-16 were truncated at the ground-water table, about two feet above the inside floor, as described in section 5. An artificial cap consisting of 1 foot of grout and 3 feet of soil was placed above the truncated tank to more closely simulate the movement of water through an "intact" tank. 


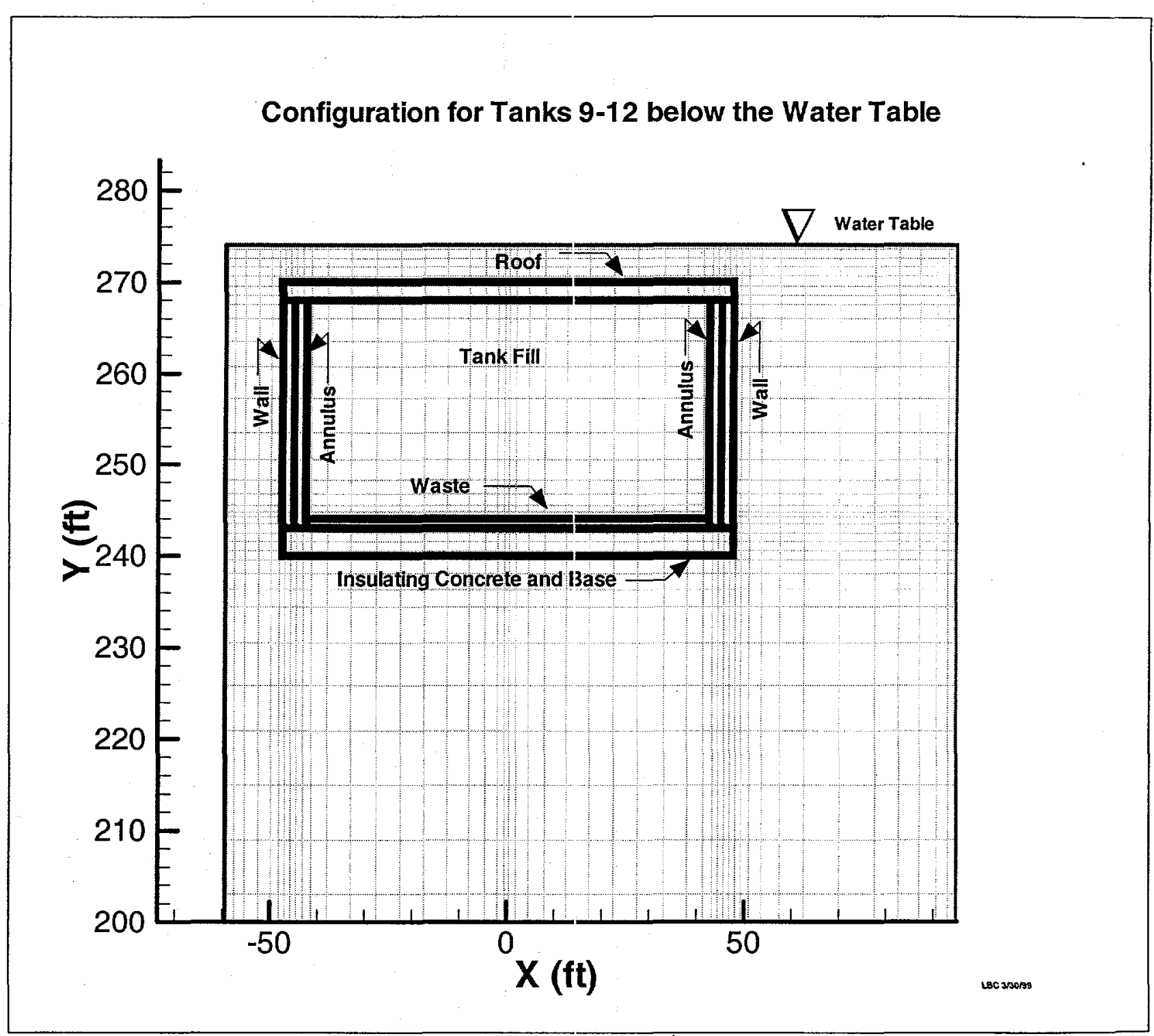

Figure 5. Tank Geometry for Water Table above Tank - Category 1 


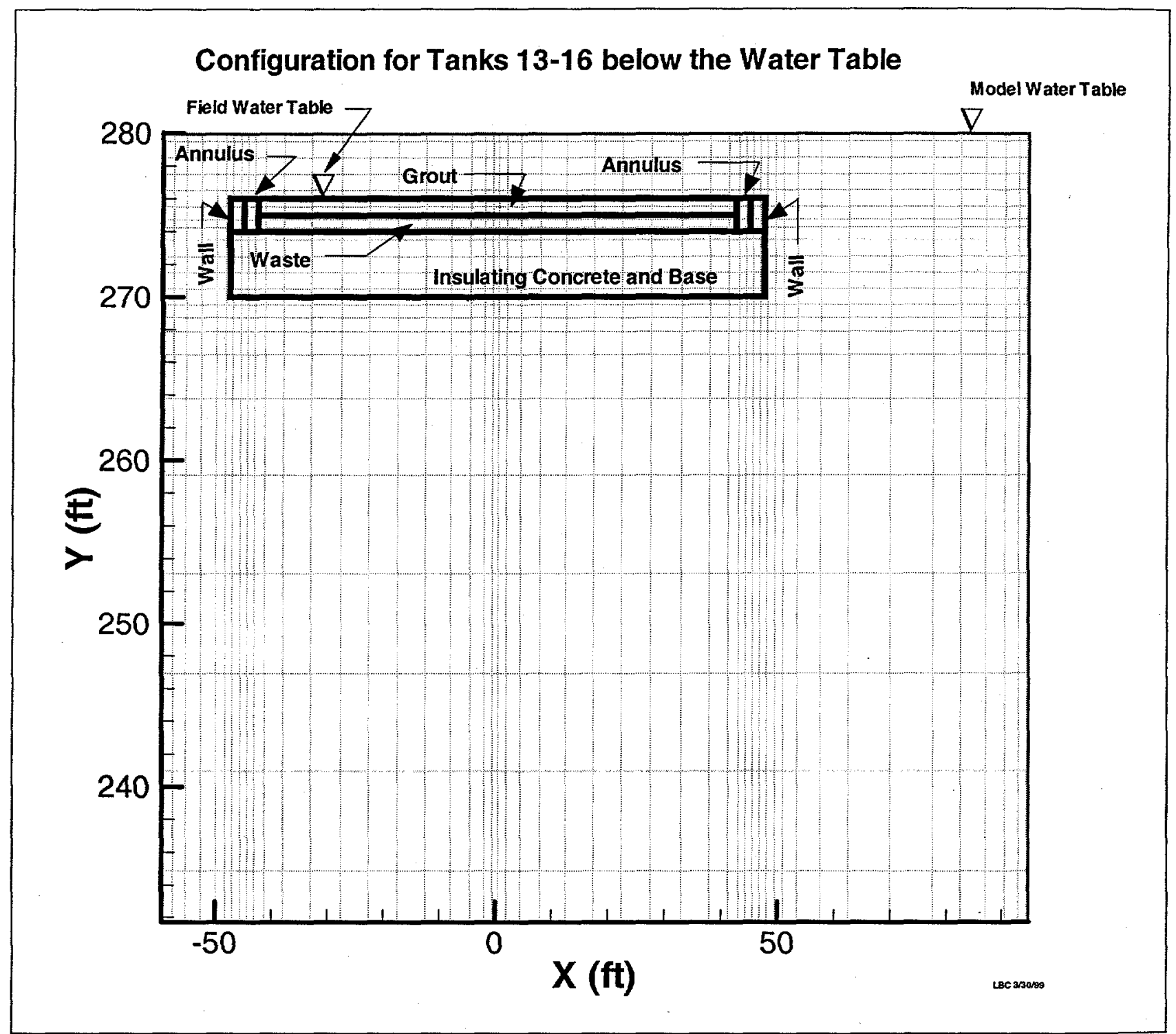

Figure 6. Tank Geometry for Water Table 2 Feet above Tank Floor Category 2 


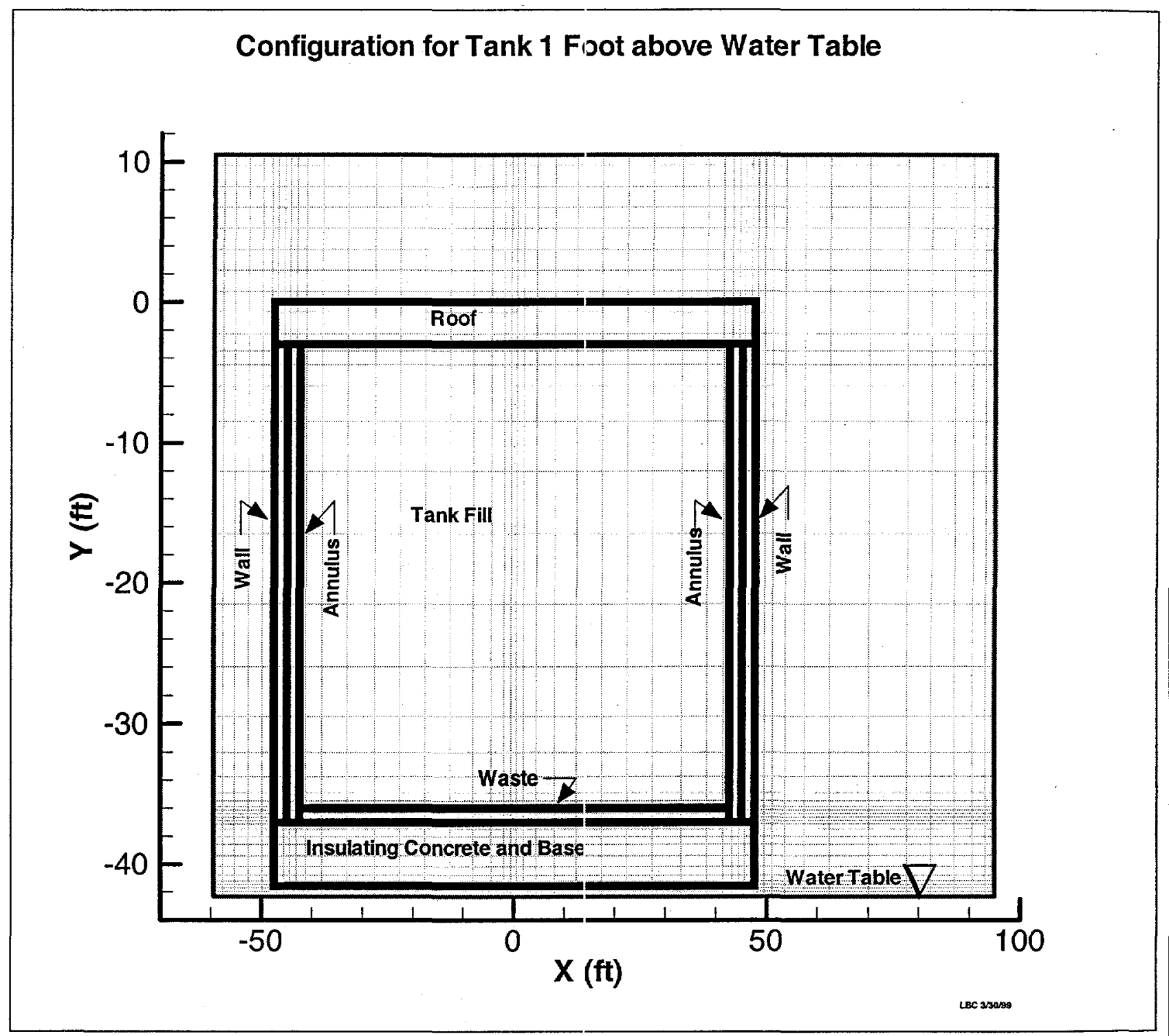

Figure 7. Tank Geometry for Water Table 1 Foot below Tank Base Category 3 


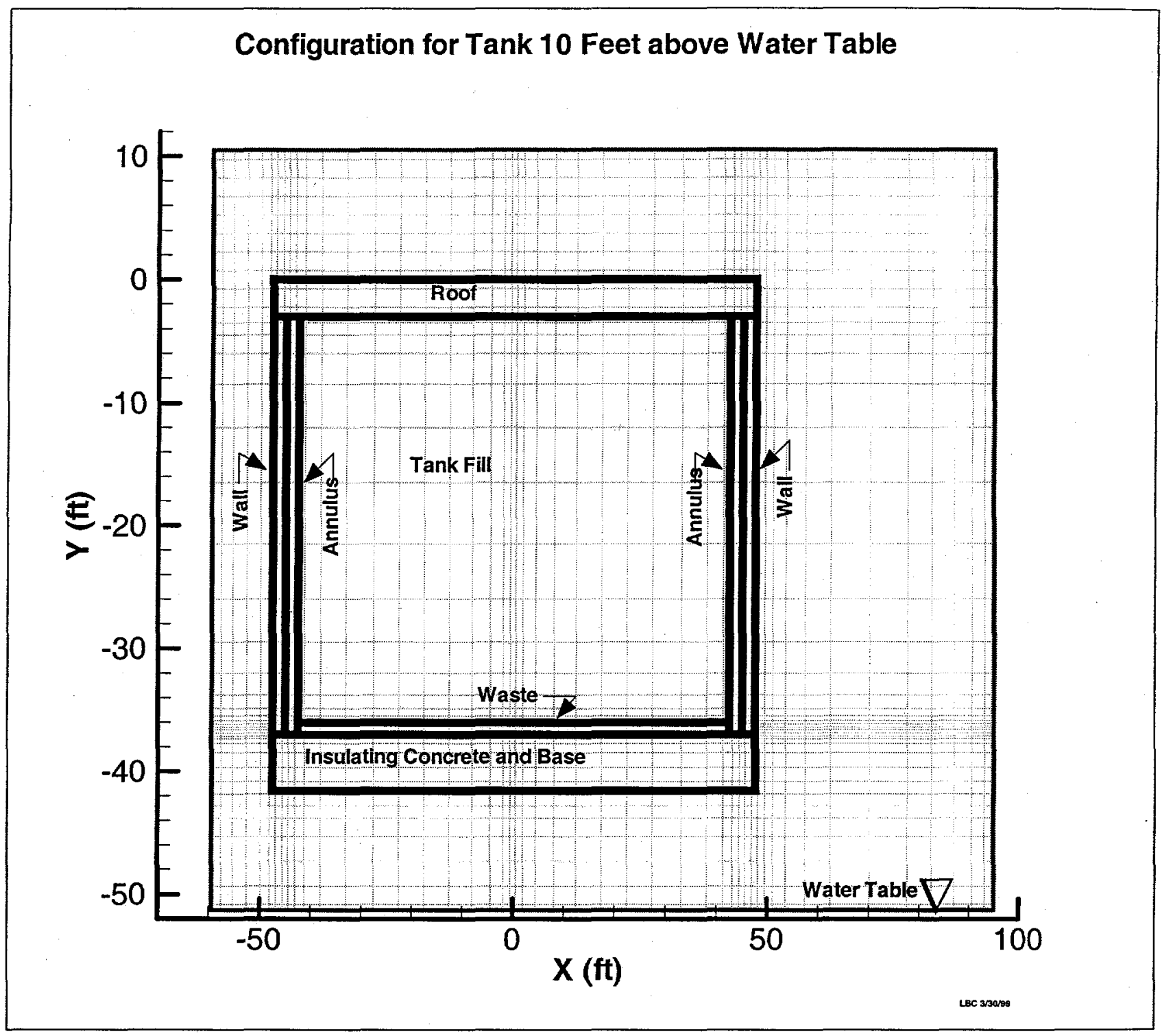

Figure 8. Tank Geometry for Water Table 10 Foot below Tank Base Category 4 


\subsubsection{Tank-release Flow Model}

Because boundary conditions are applied at the outside edge of the modeling domain, an artificial four-foot thick cap allows the water to adjust to the relatively low-conductivity concrete and primarily flow around it, rather than through it. Without the artificial soil cap, the boundary condition would be applied directly to the concrete, producing modeling results not reflective of field conditions.

After assigning flow parameters, each flow model was exercised until steady-state conditions were attained. The intact-case flow model was used for the first 1,000 years of transport analysis, while the failedcase flow model was used for all transport beyond 1,000 years.

\subsubsection{Tank-release Contaminant-Transport Model}

After executing the numerical flow models, the steady-state saturations and fluxes were combined with the transport parameters to produce the numerical transport models. The transport models were executed for the first 1,000 years using the intact-case steady-state saturations and water fluxes. Beyond 1,000 years, the failed-case steady-state saturations and water fluxes were used for the transport models. The tank-release contaminant-transport models generated aquifer contaminant loads consisting of fluxes of contaminants to the aquifer.

\subsection{Aquifer Models}

The aquifer model consists of two aquifer-flow models, one for the FTank farm and one for the H-Tank farm, and two associated aquifer contaminant-transport models. Results from the tank-release contaminant-transport model and the aquifer-flow model are required inputs for the aquifer contaminant-transport model (see Figure 2). The geometry, flow model and contaminant-transport model are described below.

\subsubsection{Geometry}

The geometry is a refined subset of the General Separations Area (GSA) studied by Flach and Harris (1999). Plan-view meshes for the F- and $\mathrm{H}-$ Tank farm models are shown in Figures 9 and 10 , respectively. Outlines of tanks, buildings, roads and streams a.re provided for orientation.

The overall extent of each modeling dome.in was determined by examining the streamlines (presented in section 7.3) that emanated from the tanks. A rectangular mesh was sized and oriented to try to accomplish three purposes as follows:

- Align with the tanks, so that most tanks lie predominantly within one horizontal cell

- Minimize the overall mesh size

- Contain essentially all the streamlines. 


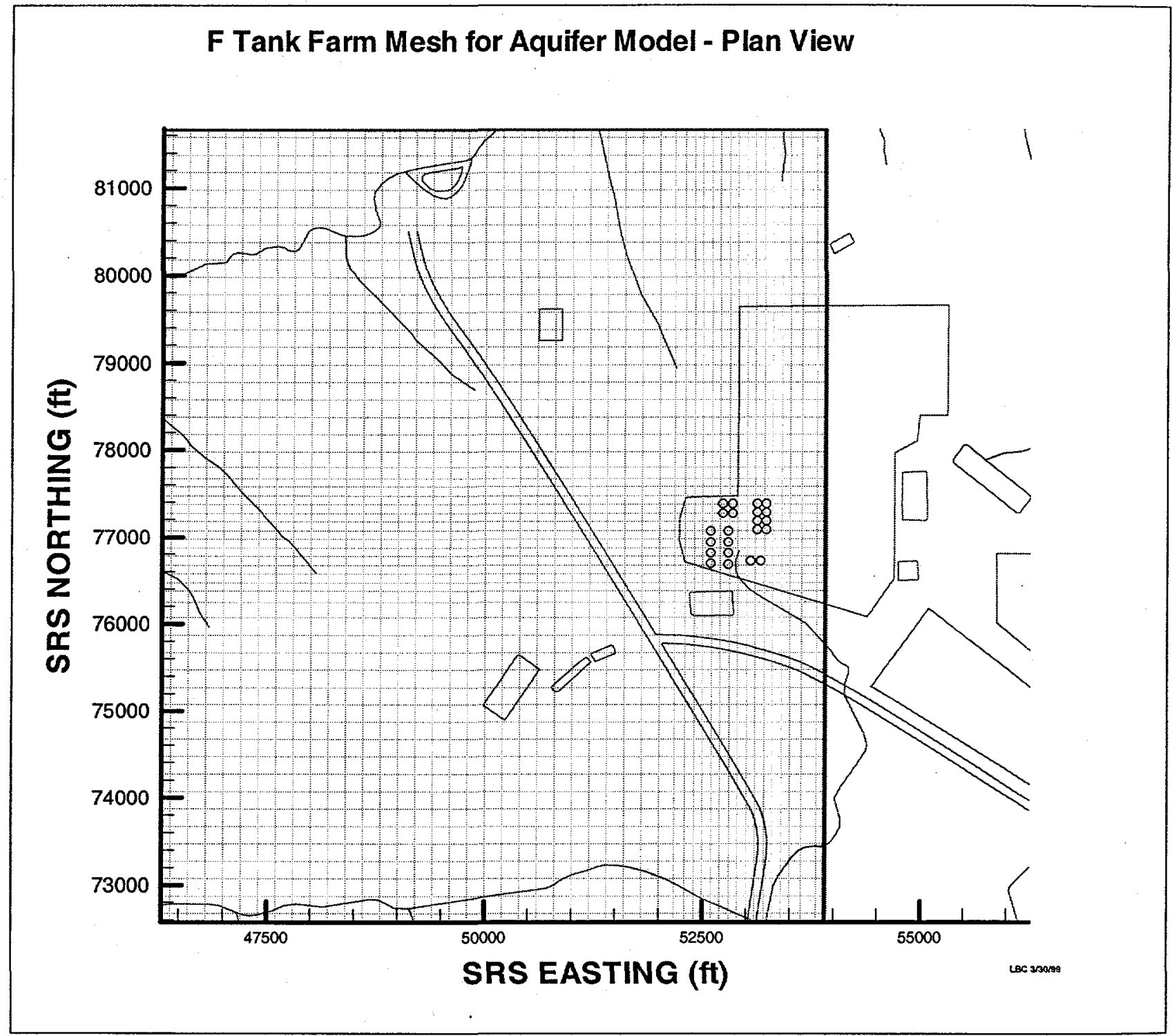

Figure 9. Plan-view Mesh for F-Tank Farm 


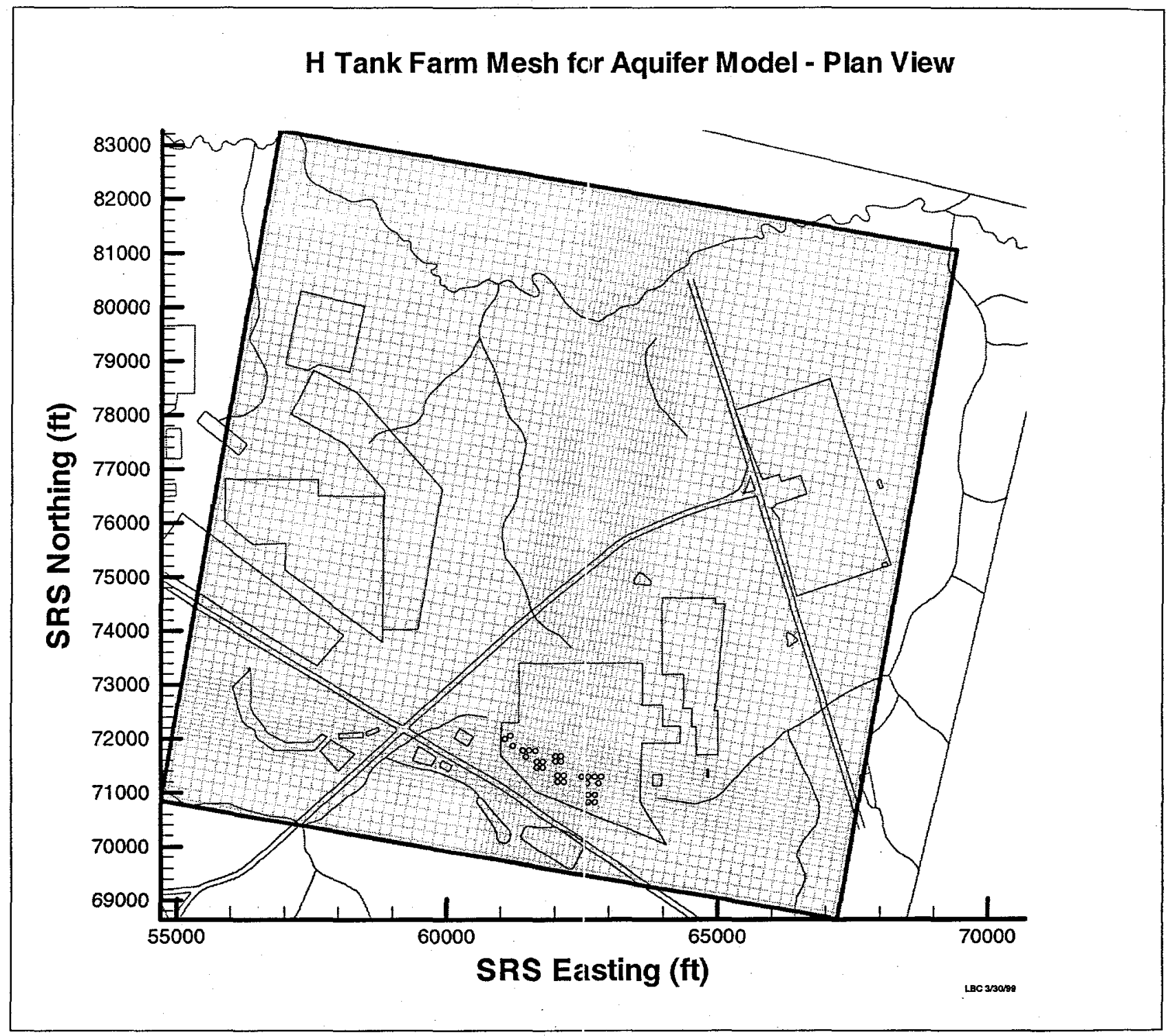

Figure 10. Plan-view Mesh for H-Tank Farm 
The final mesh was a compromise of the purposes stated above. The mesh was refined near the tanks, such that the cells were $100-\mathrm{ft}$ squares horizontally. Outside the tank farms, the cell size was stepped up to 150-ft squares then to $200-\mathrm{ft}$ squares to match the original GSA mesh size.

Flach and Harris (1999) summarize the flow-model geometry for the GSA model. "The areal resolution of the flow model is $200 \mathrm{ft}$ square except in peripheral areas. There are 108 elements along the east-west axis, and 77 elements along the north-south axis. The 'upper' aquifer zone of the UTR aquifer unit is represented with 9 finite-elements in the vertical direction. The vadose zone is included in the model. The 'lower' aquifer zone contains 5 finite-elements while the 'tan clay' confining zone separating the aquifer zones is modeled with 2 vertical elements. The Gordon confining and aquifer units each contain 2 elements, for a total of 20 vertical elements from ground surface to the bottom of the Gordon aquifer. The 3D mesh size is therefore $108 \times 77 \times 20=166,320$ elements or $109 \times 78 \times 21=178,542$ nodes. The relatively fine vertical resolution of the model is designed to support subsequent contaminant transport analyses."

\subsubsection{Aquifer-flow Model}

The refined F-farm and H-farm models used boundary conditions derived from the GSA model. Material properties were interpolated from the GSA model. The refined flow models were solved to establish steady-state conditions.

The aquifer-flow models in this report differ from the Flach and Harris (1999) model, because the hydraulic conductivity was decreased by an order of magnitude for the green clay confining the Gordon aquifer. This change was made based on tritium studies (Flach, 1998) accomplished after the original (1997) version of the Flach and Harris (1999) model was established. This change is in agreement with the Composite Analysis flow model (DOE, 1997b).

\subsubsection{Aquifer Contaminant-Transport Model}

Geometries, material properties, saturations, and volumetric water fluxes were exported from the aquifer-flow model to the aquifer contaminant-transport model. Aquifer contaminant loads were derived from the contaminant fluxes to the aquifer generated by the tankrelease contaminant-transport models. Contaminant fluxes for tankrelease categories where tank wastes were below the water table were loaded into multiple aquifer cells when the tank occupied more than one aquifer cell, while contaminant fluxes for tanks above the water table were loaded into a single aquifer cell.

\section{- Tank-release Categories 1 and 2: Tank wastes submerged}

Contaminant fluxes for categories 1 and 2 exited the tank along the right-hand side and through the bottom of the tank. The flux through the bottom of the tank was recorded for every two years as one contaminant source for input to the aquifer contaminant-transport model. Along the right-hand side, the fluxes were recorded for every 
two years by sets of cells; each set of tank-release cells represented one aquifer-model cell (see Section 4.2.4 for the vertical discretization of the tank-release model cells). The fluxes for each set of cells became a separate contaminant source to load the aquifer contaminant-transport model. The contaminant source for the lowest set of tank-release cells, was assigned to the same aquifer-model cell as the flux through the bottom of the tank. The contaminant sources for the other sets of cells were assigned to aquifer cells that were stacked directly above the bottom aquifer load cell.

The 5,000 fluxes created by recording every two years were reduced to 50 for input to the aquifer contaminant-transport model. A computer program was used to scan the 5,000 fluxes to ensure that all peaks and valleys were duplicated, along with any major slope changes.

\section{- Tank-release Categories 3 and 4: Tank wastes entirely above the ground-water table}

Contaminant fluxes for categories 3 and 4 exited the tank only through the bottom of the tank. The construction of the contaminant sources for the aquifer contaminant-transport model was identical to that for category 1 and 2 fluxes through the bottom of the tank.

\subsection{POST-MODELING ANALYSIS}

The numerical models produce intermediate results. Post-modeling analysis compares sums of results from single-tank-load models with results from a single model consisting of multiple-tank loads. Peak seepline cells can be found and plume interactions can be detected using relative comparisons.

For absolute rather than relative comparisons, post-modeling analysis scales modeling results by tank inventories. When a single tank was modeled, the numerical models used unit inventories as input to generate fractional concentrations and fluxes as outputs. For a single-tank model, the concentration curve at a single seepline cell is an influence curve describing the effect of a unit-curie tank load from that specific tank on that specific seepline cell. When multiple tanks were modeled, the numerical models used unit inventories in each tank as input, which generated summed concentrations and fluxes as outputs that can only be used for relative comparisons. Combinations of single-tank-load models can produce a rapid-screening capability after checking results with total tank-farm results.

\subsection{Rapid Screening Tool}

The Rapid Screening Tool provides the means of reducing preliminary tank-closure analyses to essentially spreadsheet calculations. For the current report, major pieces have been cieveloped to allow the final development of the Rapid Screening Tool.

The Rapid Screening Tool requires each individual tank to be analyzed using a unit inventory with concentration results recorded for each seepline cell to generate a complete set of influence curves. The actual or expected tank inventories can be multiplied by the influence curves for each tank and the scaled results can be summed at each seepline cell for each time step. The scaled and summed results should 
approximate the results that a new system-wide modeling effort would produce if nothing but inventories changed.

These efforts are required for each contaminant of concern.

Solubility-limited species cannot be analyzed using the Rapid screening Tool, because results are not linearly scaleable.

This approach should properly account for diffusion in the aquifer. For example, assume that two identical tanks have contamination transported through parallel and adjacent flow paths. If the tanks are modeled independently, then diffusion occurs across the interface between the paths because the concentration in the adjacent flow path is zero. If the tanks are modeled simultaneously, then the net diffusion across the interface between the paths is zero. However, superimposing the results from both independently modeled tanks results in zero-net diffusion, because the contribution from one tank offsets the loss from the adjacent tank. Regardless, effects of diffusion in the aquifer contaminant transport model are expected to be so small that they can be neglected. Section 7.4.4 presents limited diffusion results.

\subsection{Tank Inventories}

Tank inventories were multiplied by the model results only for comparing TC-99 results for Tanks 17 and 20 with earlier onedimensional modeling. Those tanks have been "operationally closed" and one-dimensional ground-water flow and contaminant-transport analyses were completed to support those closures. Tank inventories and comparisons between one-dimensional and multi-dimensional model results are presented in Section 7.4.5.

\subsection{MODEL RESULTS}

The primary types of modeling results for each of the four event models are shown in Table 2. Each type of result is discussed below.

Table 2. Types of Modeling Results

\begin{tabular}{|l|l|l|l|}
\hline Model & Computer Program & Event & Primary Result \\
\hline Tank-release & PORFLOW & Flow & Water Fluxes \\
\hline Tank-release & PORFLOW & Transport & $\begin{array}{l}\text { Contaminant Flux to } \\
\text { Aquifer (load) }\end{array}$ \\
\hline Aquifer & FACT & Flow & Water Fluxes \\
\hline Aquifer & PORFLOW & Transport & Seepline Concentrations \\
\hline
\end{tabular}

\subsection{Tank-release Flow Model}

The tank-release flow model generates a flow field for the entire modeling domain. Water fluxes at the sides of each cell are calculated 
from the flow field. These water fluxes transport contaminants through the modeling domain via advection.

Flow fields and water fluxes were generated for each of the four tankrelease categories. For each category, a set of two plots was generated. The first plot represents the "intact state," while the second plot represents the "failed state."

Plots of the flow-velocity fields for each of the categories are depicted in Figures 11-18. The first two plot sets depict cases of tank waste below the water table where the contaminant release to the aquifer occurs at the tank-aquifer interfaces along the outer edges of the tank. The last two plot sets are for flow within the vadose zone where the release to the aquifer occurs at the water table.

For all categories, the flow moves more easily around the intact concrete tank, rather than through it. For the failed cases the tank is no longer an impediment and the flow easily moves through the tank. For the below-water-table tank settings (Categories 1 and 2), the flow is predominantly from the left to the right with only a slight downward dip in the upper-right-hand corner of the model. For the vadose-zone tank settings, water flows around the tank for the "intact" cases, but predominantly downward for the "failed" cases. A relatively dry shadow exists beneath the tank for the unsaturated, intact cases, because the flow around the tank has only a short distance to spread laterally before it encounters the water table.

\subsection{Tank-release Transport Model}

The tank-release transport model generates concentrations and contaminant fluxes for the entire modeling domain. Of primary interest are the contaminant fluxes from the tank to the aquifer. The fluxes were recorded at two-year intervals over a period of 10,000 years. TC99 and I-129 fluxes for each tank-release category are plotted in Figures 19-22.

Tanks that contain waste that is below the water table will release contaminants to the aquifer at the sides and bottom of the tank. For these categories, the figures show the sum of all contaminants reaching the aquifer at all locations.

For all categories, the I-129 reaches the aquifer earlier and at higher flux rates than does the TC-99. This behavior occurs because of the much higher retardation that TC-99 has in the waste form with a Kd of $1,000 \mathrm{ml} / \mathrm{g}$ versus $2 \mathrm{ml} / \mathrm{g}$ for $\mathrm{I}-129$. The failure of the concrete at 1,000 years greatly increases the flow through the tank resulting in a pronounced spike of I-129 soon afterward and a greatly increased rate of release of TC-99. The I-129 approaches a local peak for the intact case after about 500 years, then spikes after the concrete fails. The Tc-99 generally reaches or approaches a relatively flat peak after about 4,000 years. Its peak is affected by a high kd and by a limited inventory. 


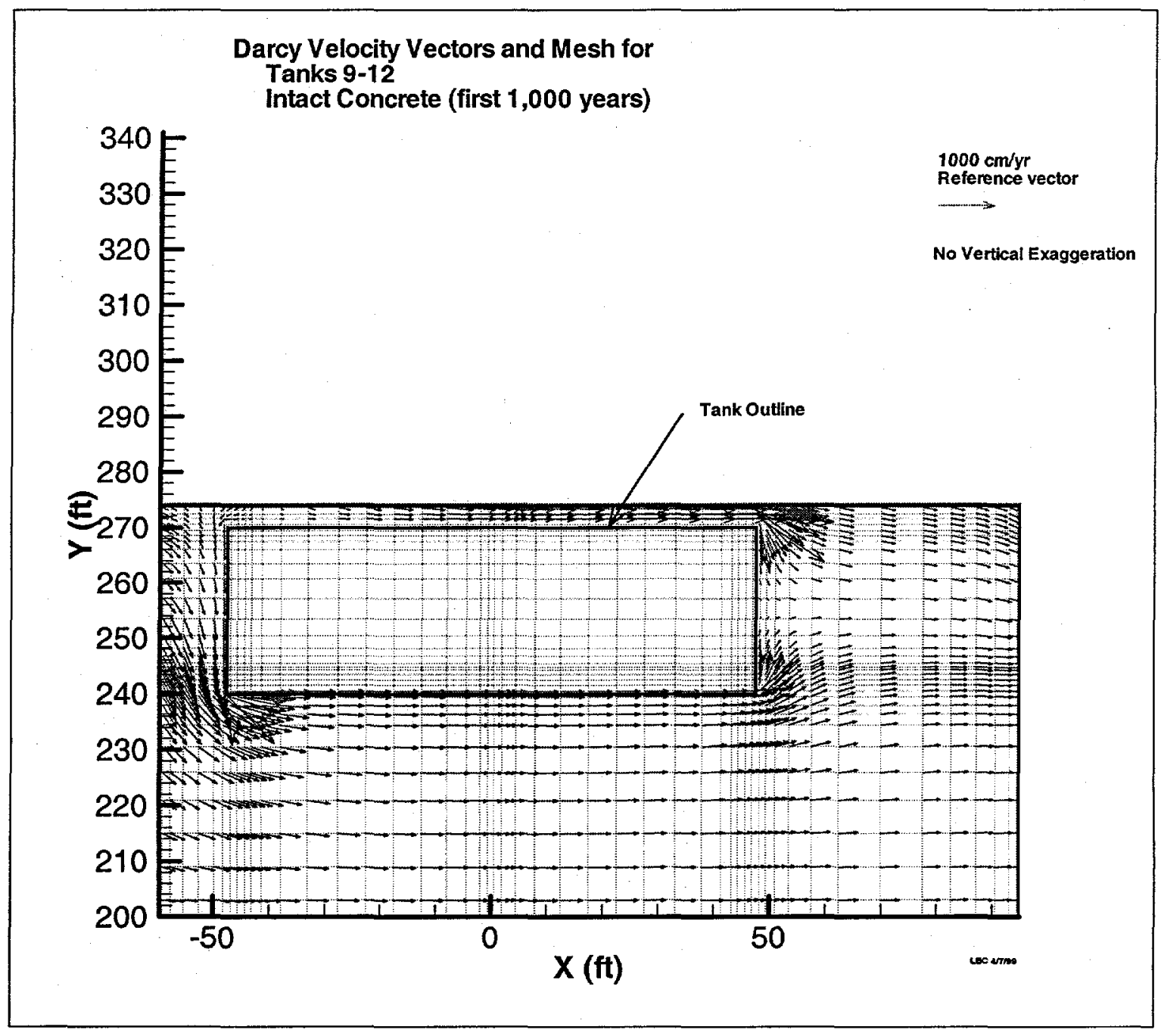

Figure 11. Velocity Field for Tanks 9-12 below water Table (Category 1) for Intact Case (first 1,000 years) 


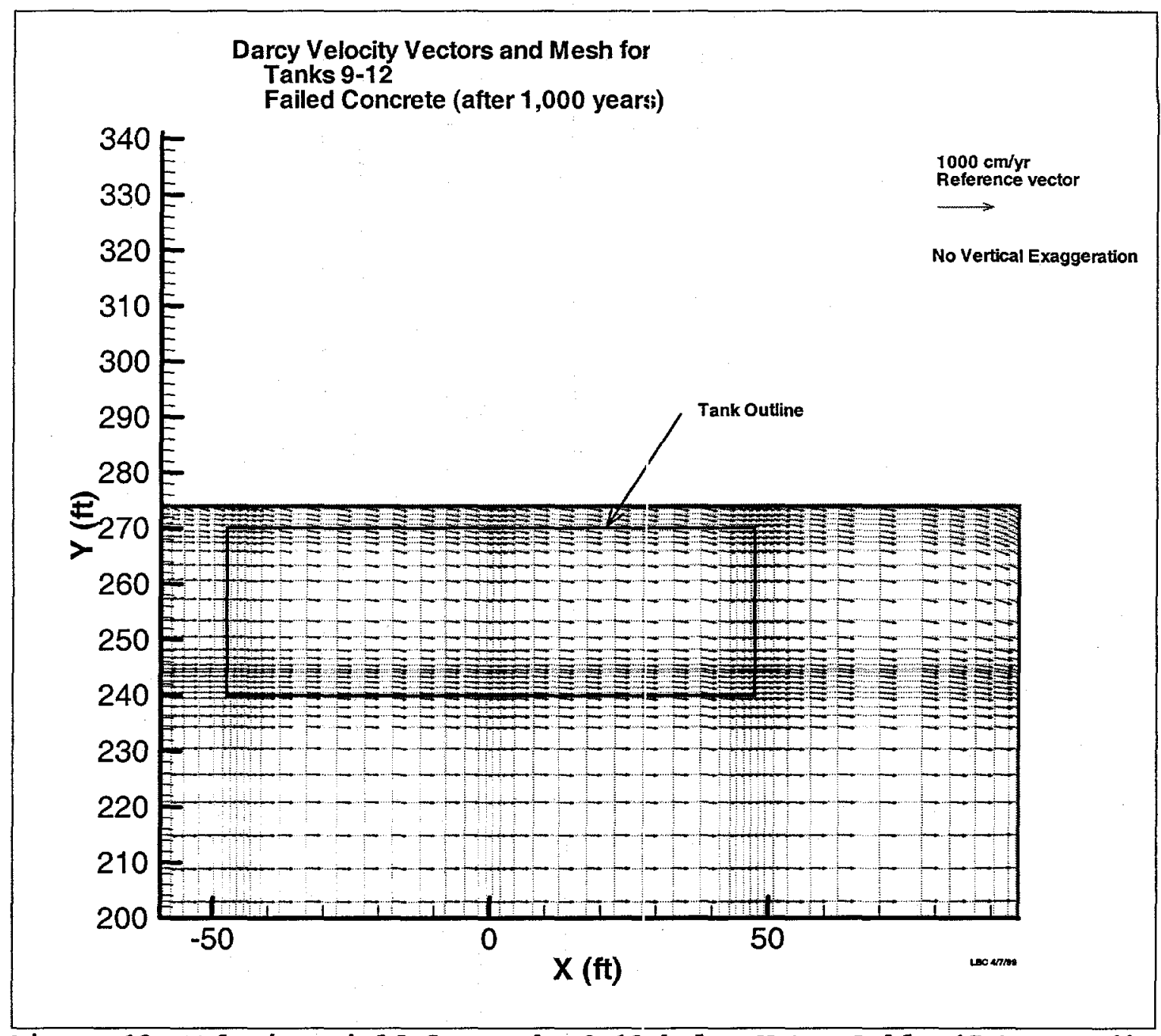

Figure 12. Velocity Field for Tanks 9-12 below Water Table (Category 1) Eor Failed Case (after 1,000 years) 
WSRC-TR-99-00100

September 24, 1999

Darcy Velocity Vectors and Mesh for Tanks 13-16

Intact Concrete (first 1,000 years)

$1000 \mathrm{~cm} / \mathrm{yr}$

Reference Vector

No Vertical Exaggeration

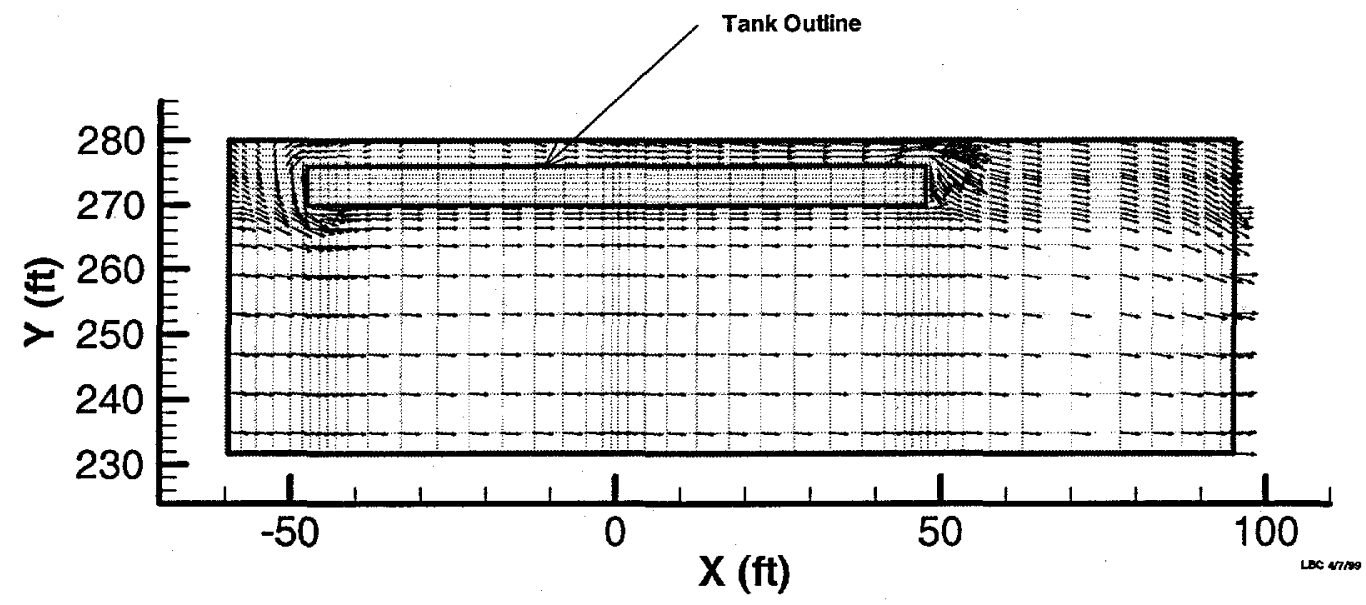

Figure 13. Velocity Field for Tanks 13-16 below Water Table (Category 2) for Intact Case (first 1,000 years) 


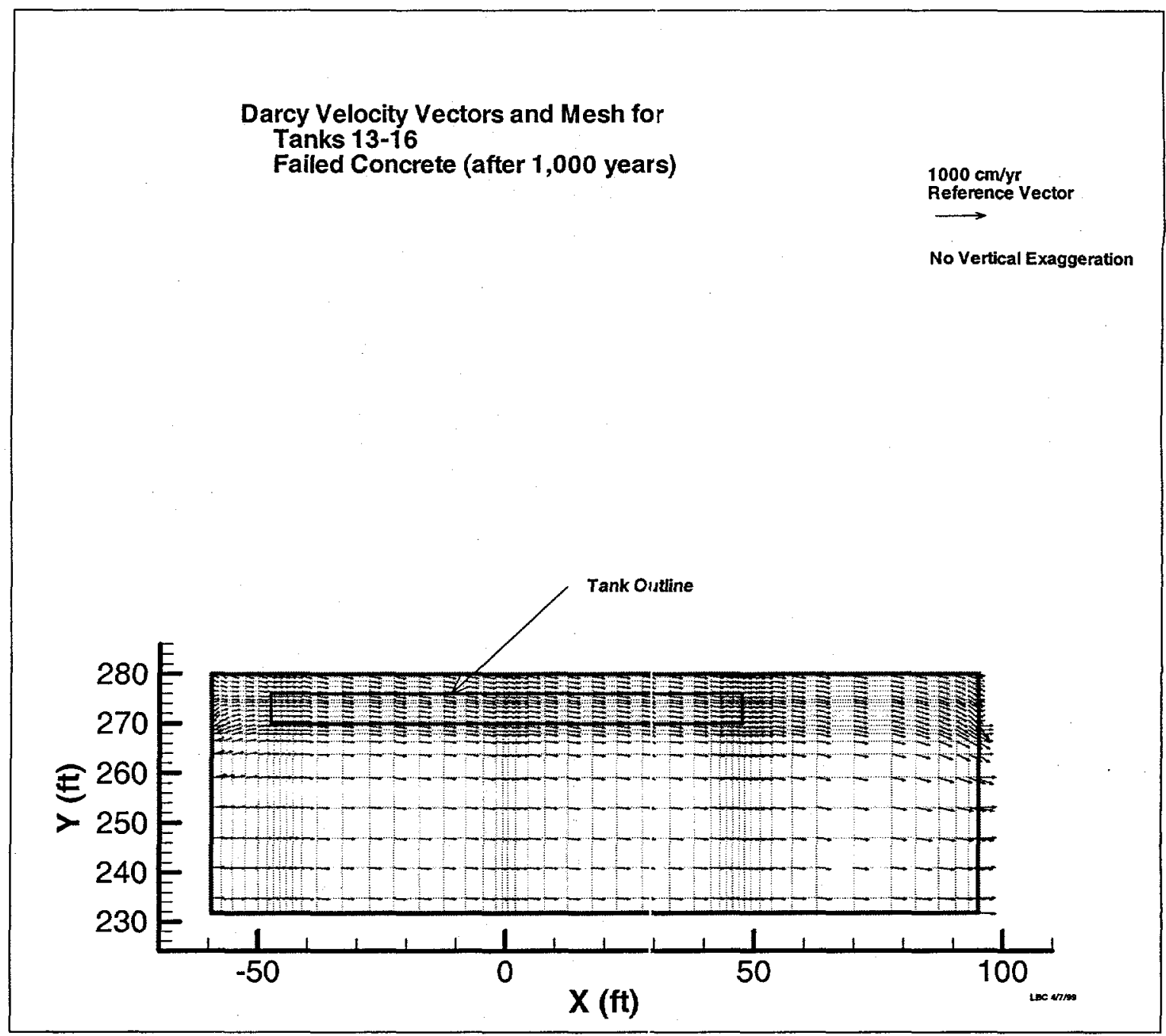

Figure 14. Velocity Field for Tanks 13-16 below Water Table (Category 2) for Failed Case (after 1,000 years) 


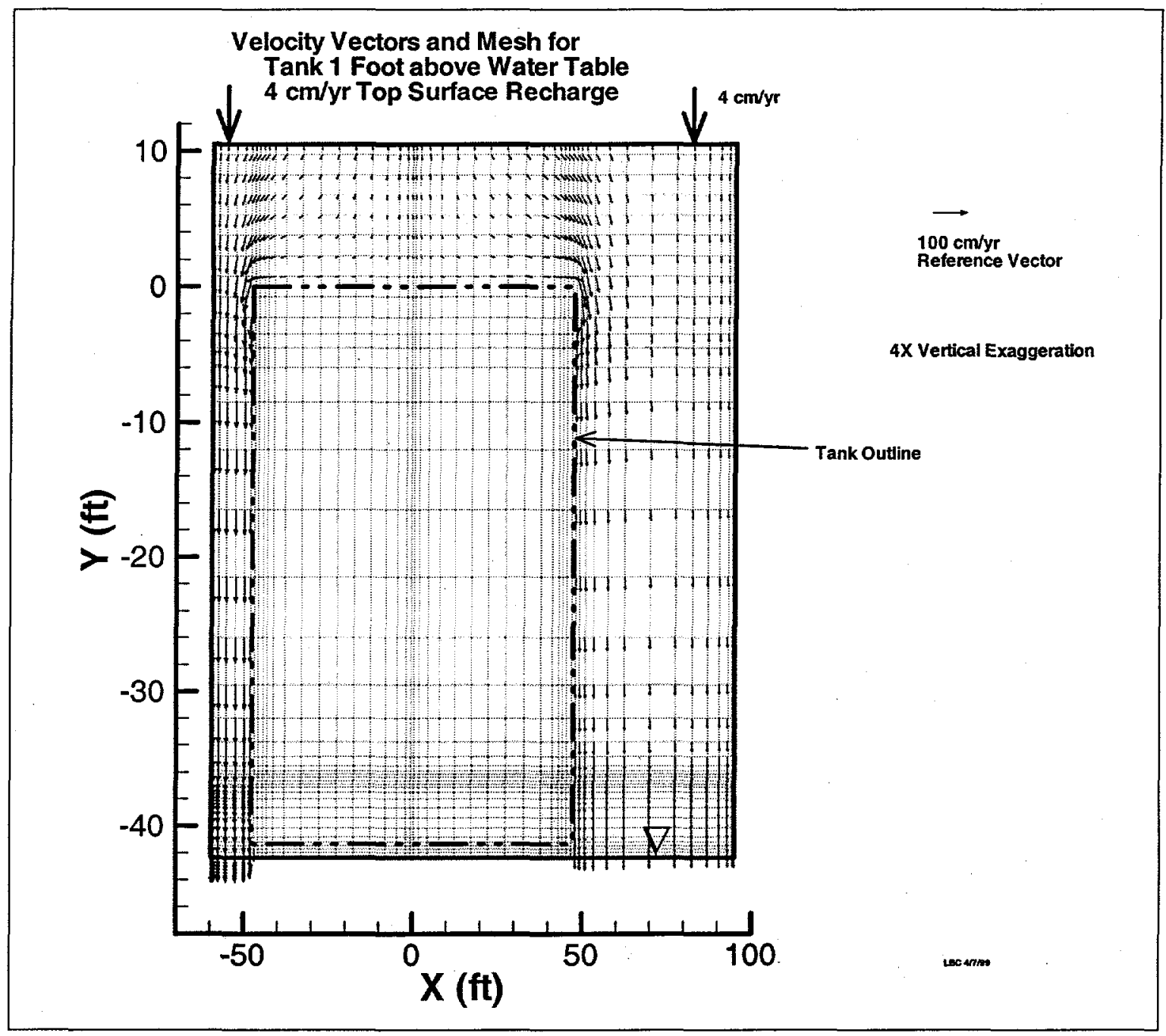

Figure 15. Velocity Field for Water Table 1 Foot below Tank Base (Category 3) for the "Intact" Case with $4 \mathrm{~cm} / \mathrm{Yr}$ Surface FIux 


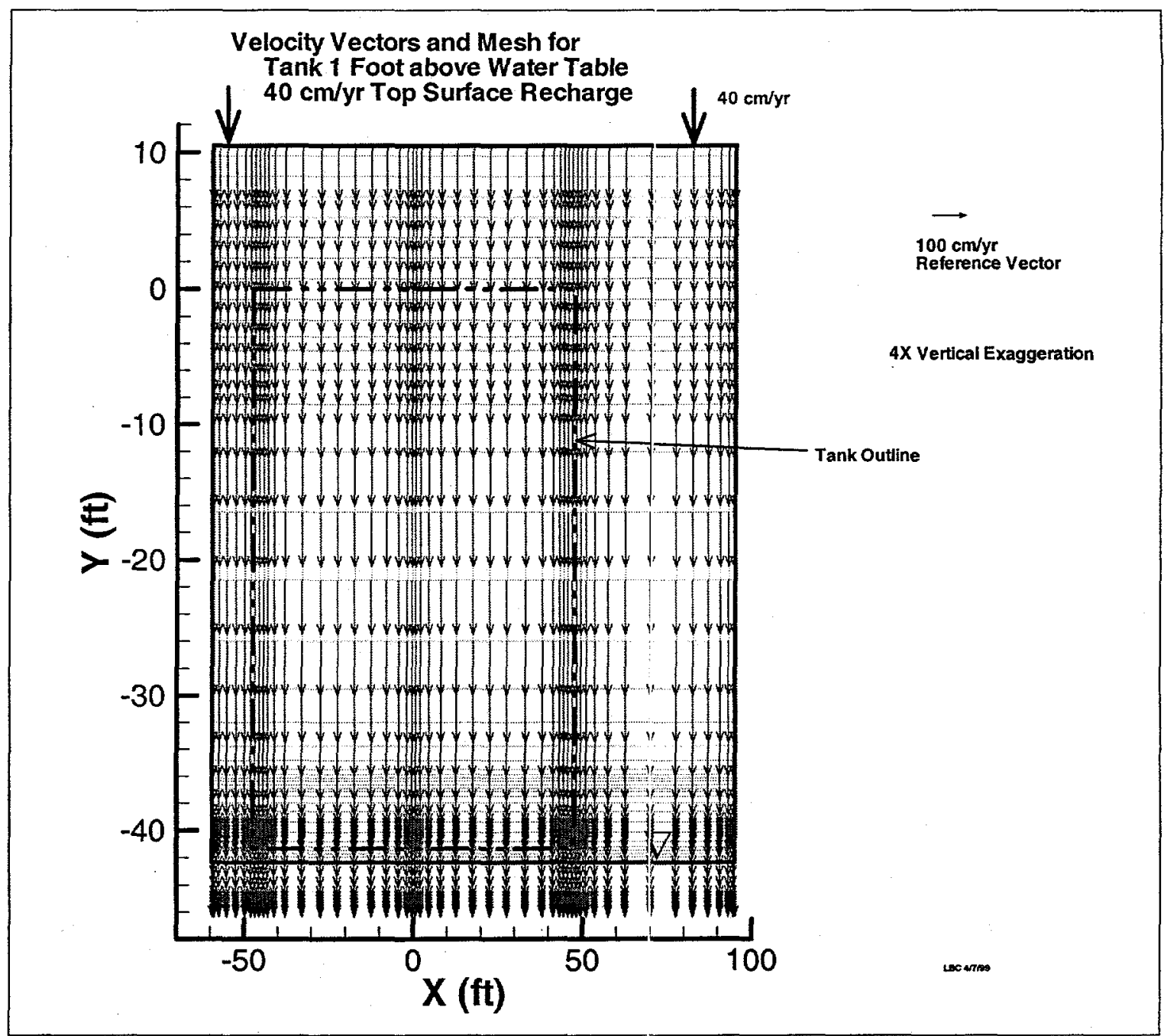

Figure 16. Velocity Field for Water Table 1 Foot below Tank Base (Category 3) for the "Failed" Case with $40 \mathrm{~cm} / \mathrm{yx}$ Surface Flux 


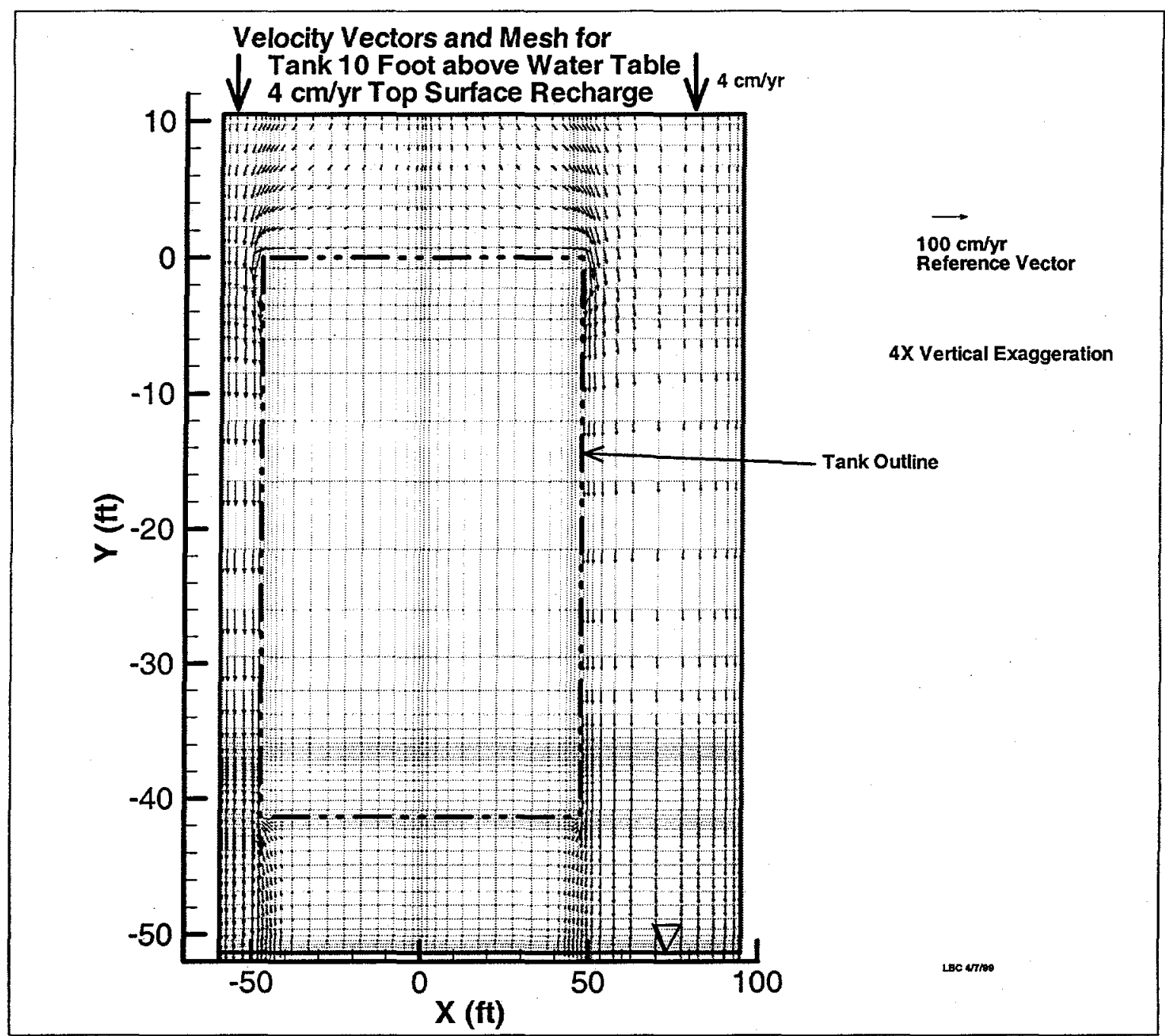

Figure 17. Velocity Field for Water Table 10 Feet below Tank Base (Category 4) for the "Intact" Case with $4 \mathrm{~cm} / \mathrm{yr}$ surface Flux 


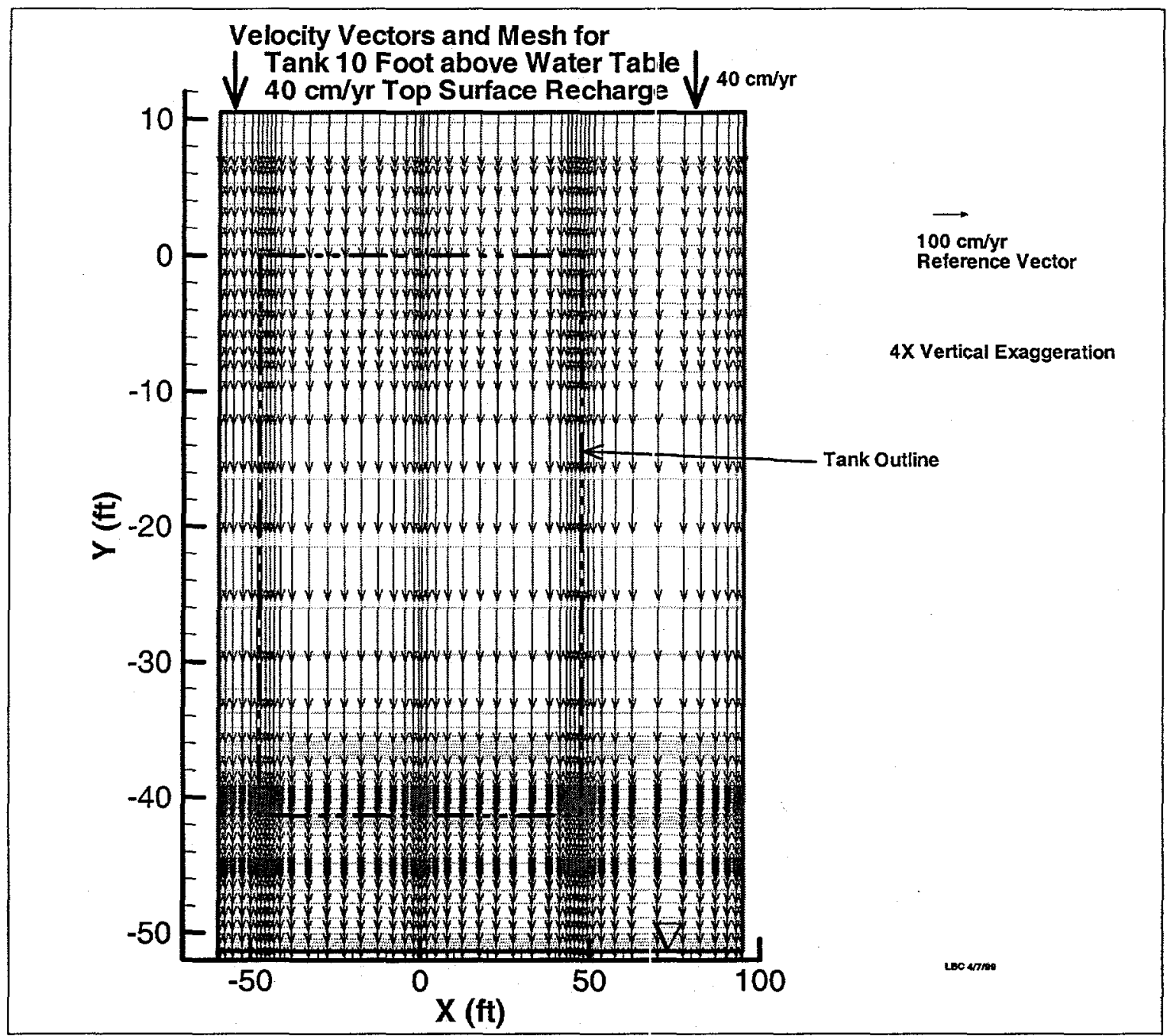

Figure 18. Velocity Field for Water Table 10 Feet below Tank Base (Category 4) for the "Failed" Case with $40 \mathrm{~cm} / \mathrm{yr}$ Surface Flux 


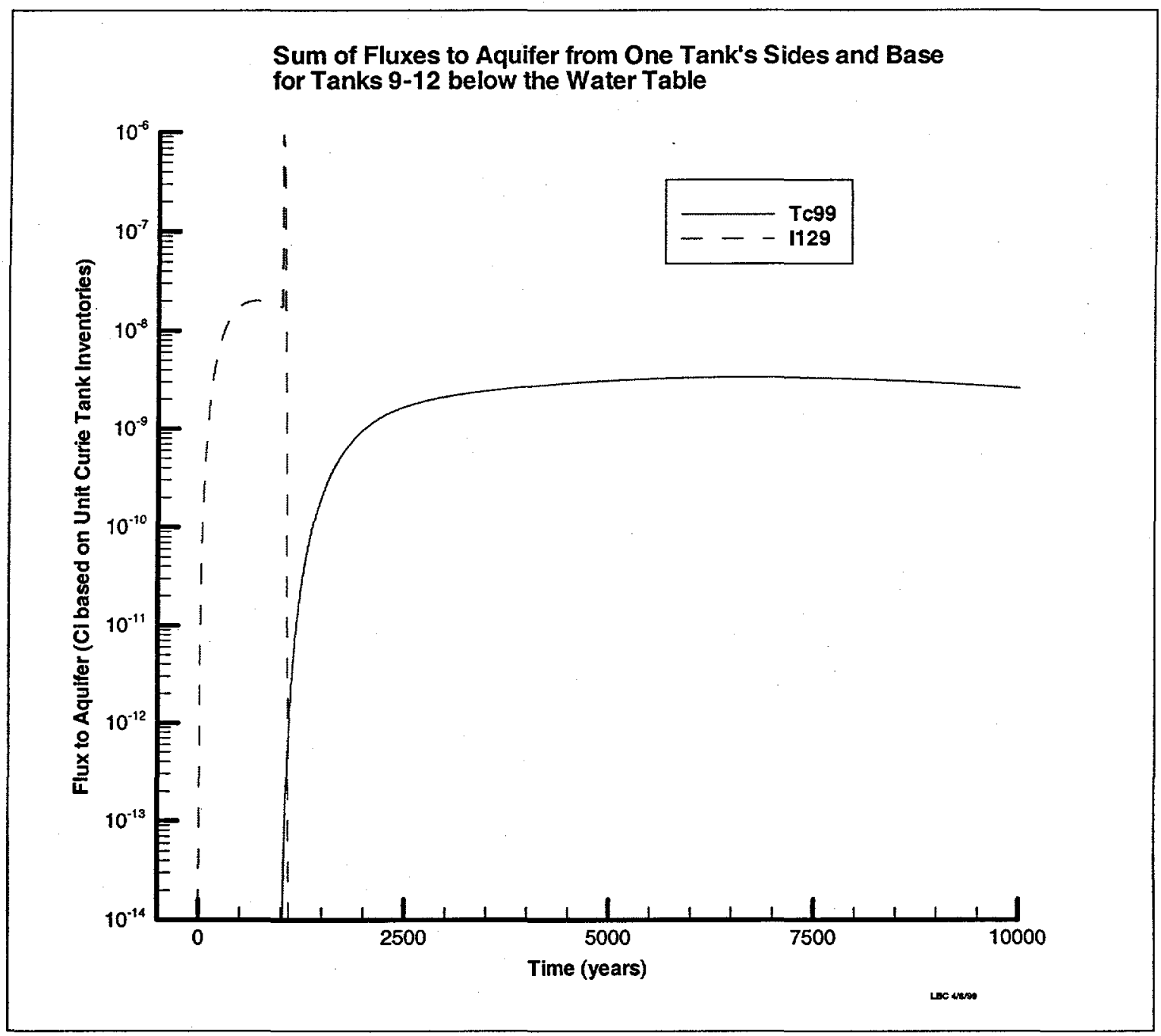

Figure 19. Sum of Contaminant Fluxes to Aquifer for Each Tank with the Water Table above the Tank - Category 1 


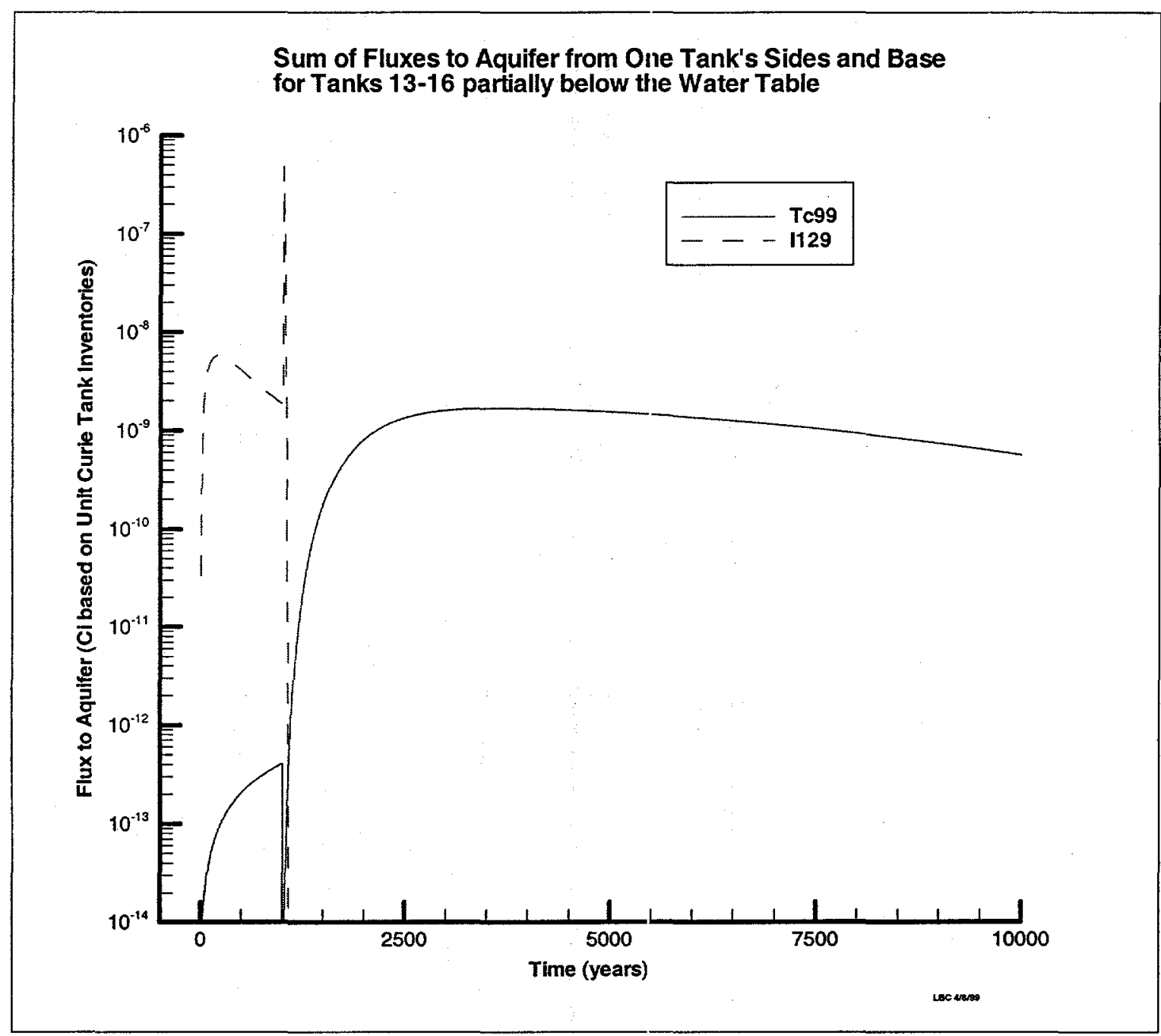

Figure 20. Sum of Contaminant Fluxes to Aquifer for Each Tank with the Water Table 1 Foot above the waste - Category 2 


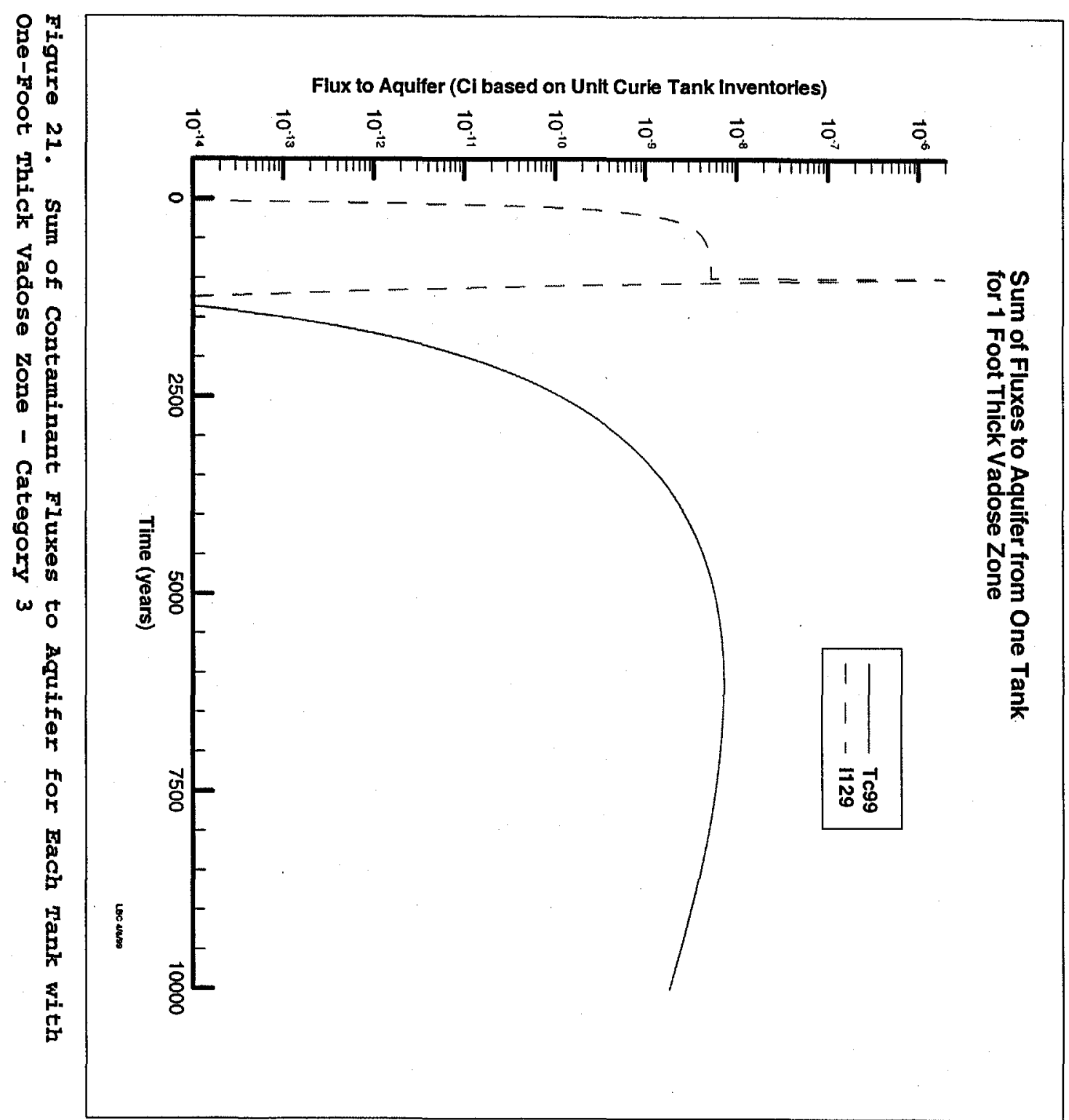


Sum of Fluxes to Aquifer from Orie Tank for 10 Foot Thick Vadose Zone

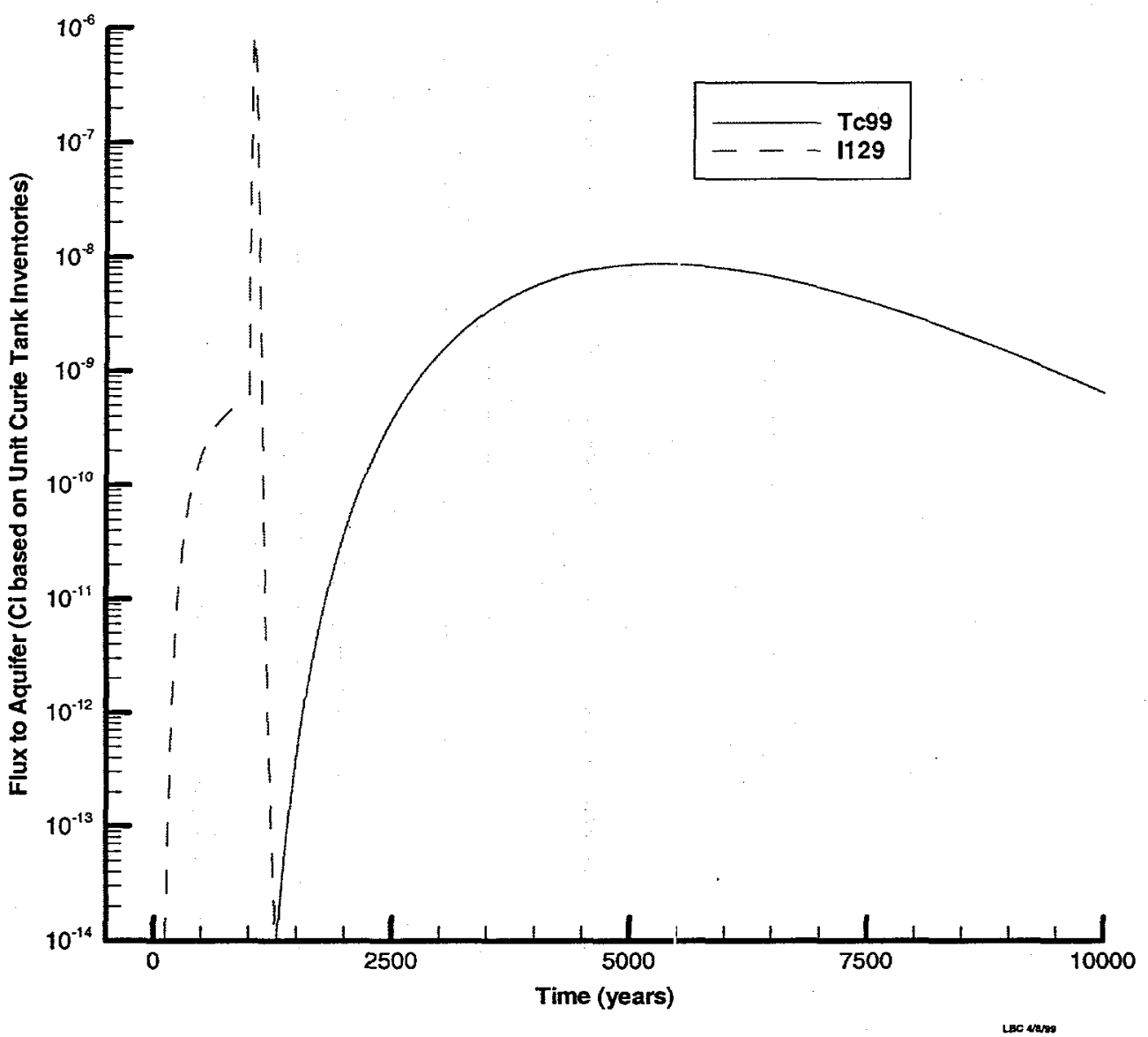

Figure 22. Sum of Contaminant Fluxes to Aquifer for Each Tank with Ten Foot Thick Vadose zone - Category 4 
The early local peak for Tc-99 from Tanks 13-16 does not appear in any of the other cases. This may be the result of the modeling only a portion of the tank height. Diffusion through the top of the tank could artificially be influencing results. Because this early local peak is about four orders of magnitude below the ultimate peak its impact is minimal.

\subsection{Aquifer-flow Model}

The aquifer-flow model generates a flow field that is a subset of the GSA model. Flach and Harris (1999) generated the GSA flow fields. The F-tank farm submodel and the H-tank farm submodel were developed for this study.

Plan views of streamlines for the $F$ - and $H$-tank farms are shown in Figures 23 and 24, respectively. A streamline maps the journey of a water particle from a tank to its exit at the edge of the modeling domain, typically discharging to a seepline. Several particles were initially released from various depths around the perimeter of each tank to generate the set of streamlines. Streamlines provide information about travel paths, seepline locations and possible plume interactions.

For the F-tank farm, almost all streamlines head to the Upper Three Runs (UTR) creek. Part of the flow from the southeastern set of tanks ( 33 and 34) moves toward the Four Mile Branch (FMB) creek. Kinks in the streamlines occur where the flow breaks through the "green clay" into the Gordon aquifer and abruptly changes direction. Streamlines reflect the predominant direction of flow, but all flows do not travel solely along the streamlines, nor do all contaminants.

For the H-tank farm, streamlines head in many different directions. A split in the flow directions occurs in the center of the farm in the west-east direction.

Flow from tanks to the west of the split travels to three destination areas:

1) Southwest to FMB

2) Northwest to UTR

3) Almost northerly to Crouch Branch.

Some of these flows first head toward FMB before breaking through to the Gordon aquifer and finishing at UTR. The flows to FMB and to Crouch Branch occur via the upper two aquifers.

Flow from tanks to the east of the split travel northwest to UTR or northeast to the McQueen Branch creek. The flows to UTR first start traveling north toward the UTR or northeast toward the McQueen Branch creek before breaking through the "green clay" and finishing at a northwest destination along UTR. 


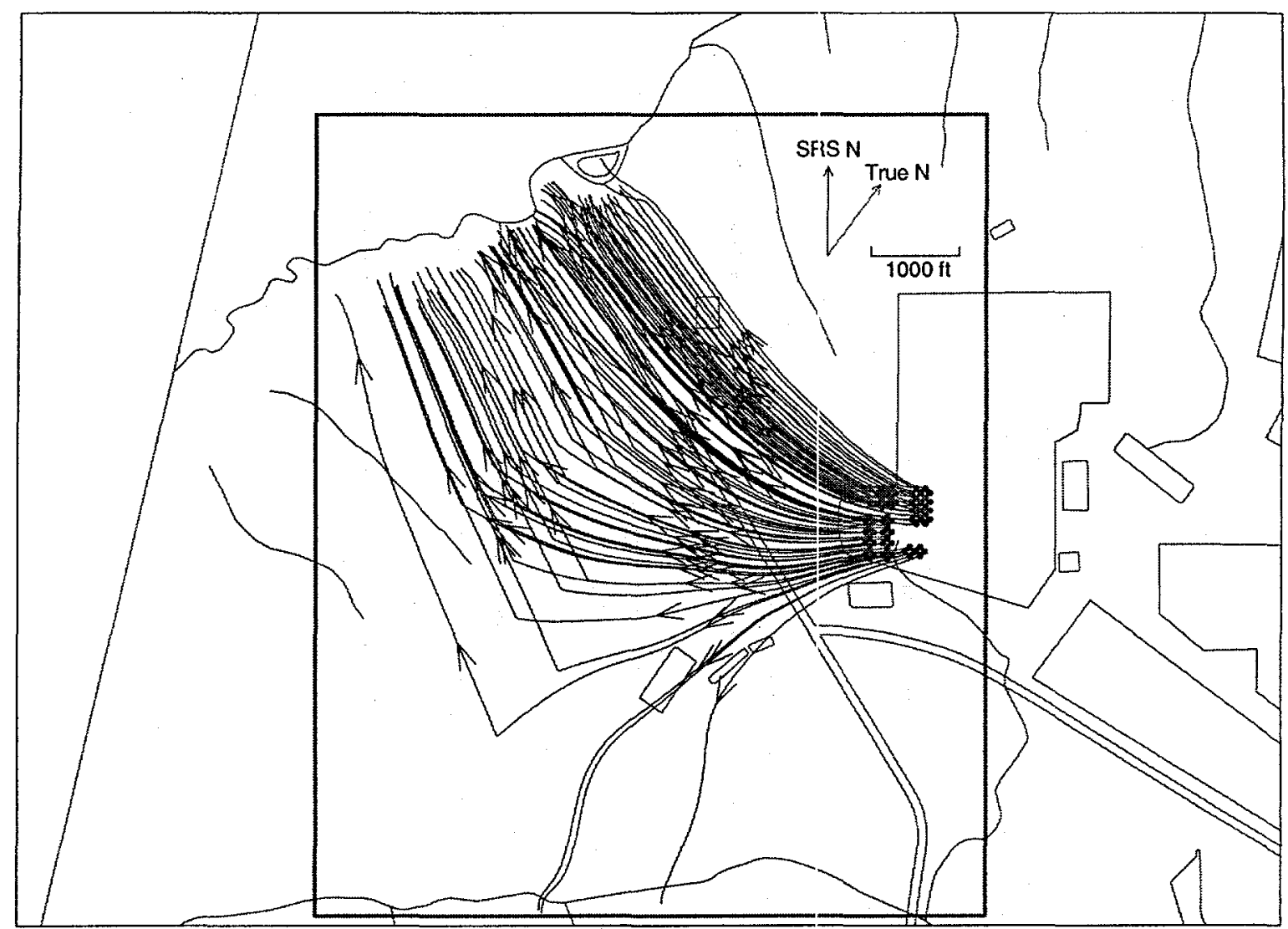

Figure 23. Streamlines from F-Farm Tanks to Seeplines 
WSRC-TR-99-00100

September 24, 1999

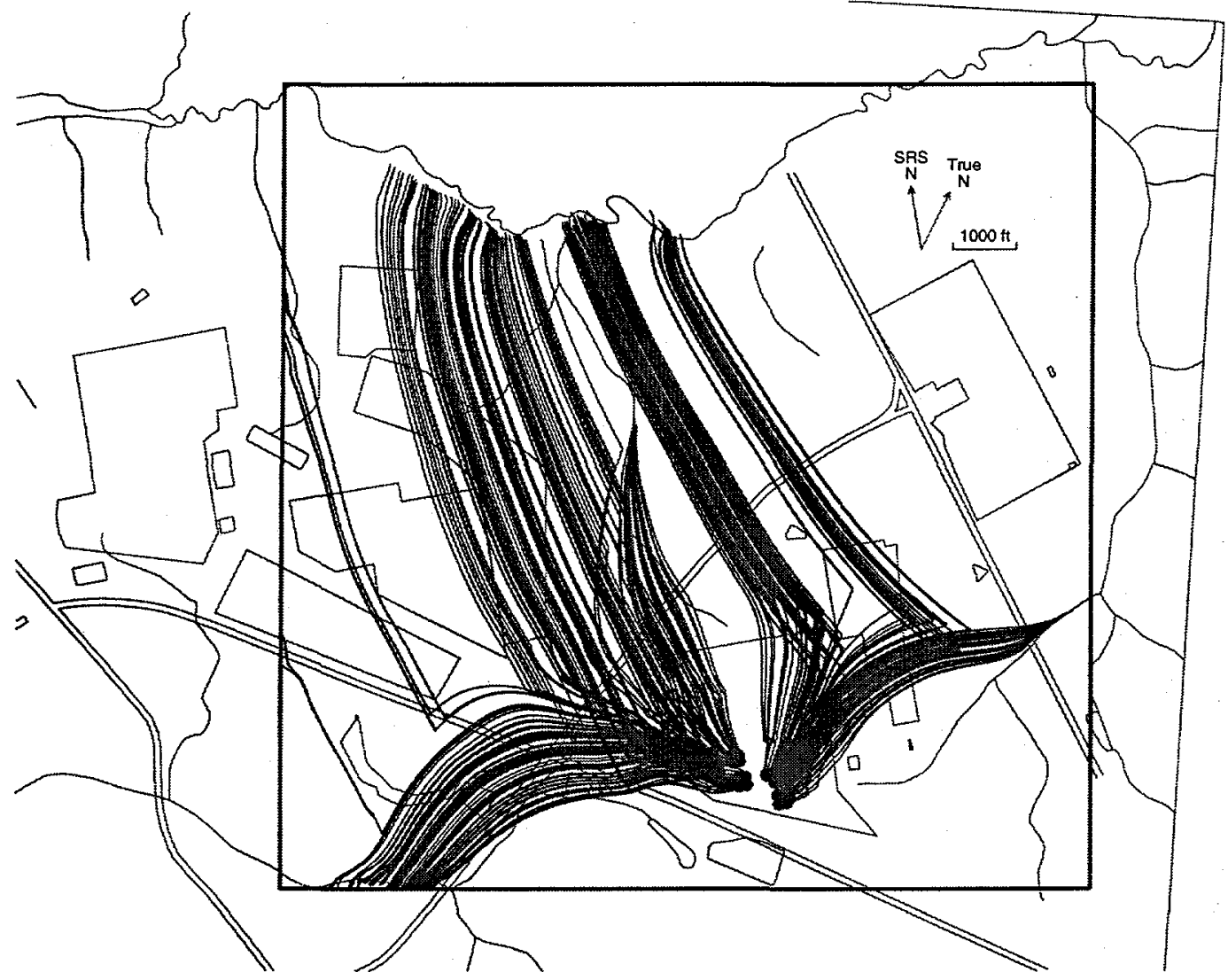

Figure 24. Streamlines from H-Farm Tanks to Seeplines 
The flow patterns are highly dependent on the assumed leakance through the "green clay" that confines the Gordon aquifer. The assumed leakance that is less than material properties indicate, results in slower penetration of water (and consequently contaminants) through the confining unit. This slower penetration creates longer travel times to seeplines for contaminants that enter the Gordon aquifer and shorter travel times to seeplines for contaminants that remain in the uppermost aquifers. More contaminants remain in the uppermost aquifers as well.

Plume interactions are most likely at tanks when they are directly downgradient of other tanks. However, plume interactions also occur away from tanks when streamlines from multiple tanks intermingle.

\subsection{Aquifer-Transport Model}

The aquifer-transport model generates concentrations at each cell throughout the modeling domain for each time step analyzed. The Ftank-farm and H-tank-farm submodel geometries from the aquifer-flow model were used for the transport submodels. A specific combination of tanks is selected as aquifer-model source loads to accomplish a specific purpose. The combinations of tanks and the purposes are presented in Table 3 . Table 3 also includes the model ID, the number of the figure showing model results, the tank farm, and the contaminant analyzed.

Table 3. Tank-Load Combinations and Purposes

\begin{tabular}{|l|l|l|l|l|l|}
\hline ID & Fig & Farm & Nuclide & Tanks & Purpose \\
\hline FA/TC & 31 & F & TC-99 & All & $\begin{array}{l}\text { Locate peak seepline cells } \\
\text { Study plume interaction }\end{array}$ \\
\hline F17/TC & 32 & F & TC-99 & 17 & $\begin{array}{l}\text { Establish influence curves } \\
\text { for other analyses }\end{array}$ \\
\hline F17\&20/TC & 34 & F & TC-99 & $17 \& 20$ & $\begin{array}{l}\text { Establish influence curves } \\
\text { for other analyses }\end{array}$ \\
\hline F17-20/TC & 35 & F & TC-99 & $17-20$ & $\begin{array}{l}\text { Check interaction with } \\
\text { other 4-packs }\end{array}$ \\
\hline HA/TC & 36 & H & TC-99 & All & $\begin{array}{l}\text { Locate peak seepline cells } \\
\text { Study plume interaction }\end{array}$ \\
\hline H13-16/TC & 37 & H & TC-99 & 13-16 & $\begin{array}{l}\text { Check interaction with } \\
\text { other 4-packs }\end{array}$ \\
\hline FA/I & 38 & F & I-129 & Al1 & $\begin{array}{l}\text { Locate peak seepline cel1s } \\
\text { Study plume interaction }\end{array}$ \\
\hline F17-20/I & 39 & F & I-129 & 17-20 & $\begin{array}{l}\text { Check interaction with } \\
\text { other 4-packs }\end{array}$ \\
\hline HA/I & 40 & H & I-129 & Al1 & Locate peak seepline celIs \\
\hline
\end{tabular}

\subsubsection{Peak Distributions in Plan View}

The concentration history at each seepline cell was scanned to find the peak concentration at that seepline cell and its time of occurrence. The ten largest peak concentrations obtained from this scan were 
plotted in plan view for the scenarios where each tank in a tank farm was loaded with an inventory of $1 \mathrm{Ci}$ of the specified contaminant. Numbers were assigned to each of these locations (see Figures 25A and 25B). Section 7.4.2 discusses naming conventions for these locations.

For the F-tank farm, all the highest concentration seepline cells lie along UTR. Almost all the locations are downgradient of the most northerly tanks in the F-tank farm and lay along the shortest paths (see Figure 23) which provide the least opportunity for dilution.

For the H-tank farm, three separate destination areas occur as follows:
1) UTR
2) $\mathrm{FMB}$
3) McQueen Branch.

Based on Figure 24 streamlines, the FMB and McQueen Branch destinations represent relatively short distances that are fed by many tanks. The UTR destination requires a longer journey, but many tanks feed that destination. Seeplines at Crouch Branch never appear on the top-ten 1ist, because it appears that fewer tanks feed that destination.

The locations of all seepline cells are shown in Figures $26 \mathrm{~A}$ and $26 \mathrm{~B}$ for the F-tank farm and the H-tank farm, respectively. To ensure that the maximum seepline concentrations were recorded, all seepline cells were monitored - 369 cells for the F-tank farm and 949 cells for the $H-$ tank farm. Seepline cells were located by finding all surface cells that discharge to creeks rather than recharge the subsurface. Figures 27-30 depict the peak concentrations at all cells in plan-view plots for the scenarios identified in Table 4.

Table 4. Plan Views of Peak Concentrations
\begin{tabular}{|l|l|l|}
\hline Figure & Tank Farm & Contaminant \\
\hline 27 & F & TC-99 \\
\hline 28 & F & I-129 \\
\hline 29 & H & TC-99 \\
\hline 30 & H & I-129 \\
\hline
\end{tabular}

For the Tc-99 in the F-tank farm (see Figure 27), the maximum cells are generally located near the eastern edge of the UTR streamlines (see Figure 23), however, relatively high concentrations exist all along the streamlines where they exit at UTR. A smattering of seepline cells along FMB show concentrations high enough to be visible in Figure 27.

For the I-129 in the F-tank farm (see Figure 28), the distribution in plan view of peak seepline cells closely approximates the pattern for Tc-99. However, the seepline cells at greater distances exhibit significantly lower relative concentrations, especially along FMB and the western reaches of UTR. 


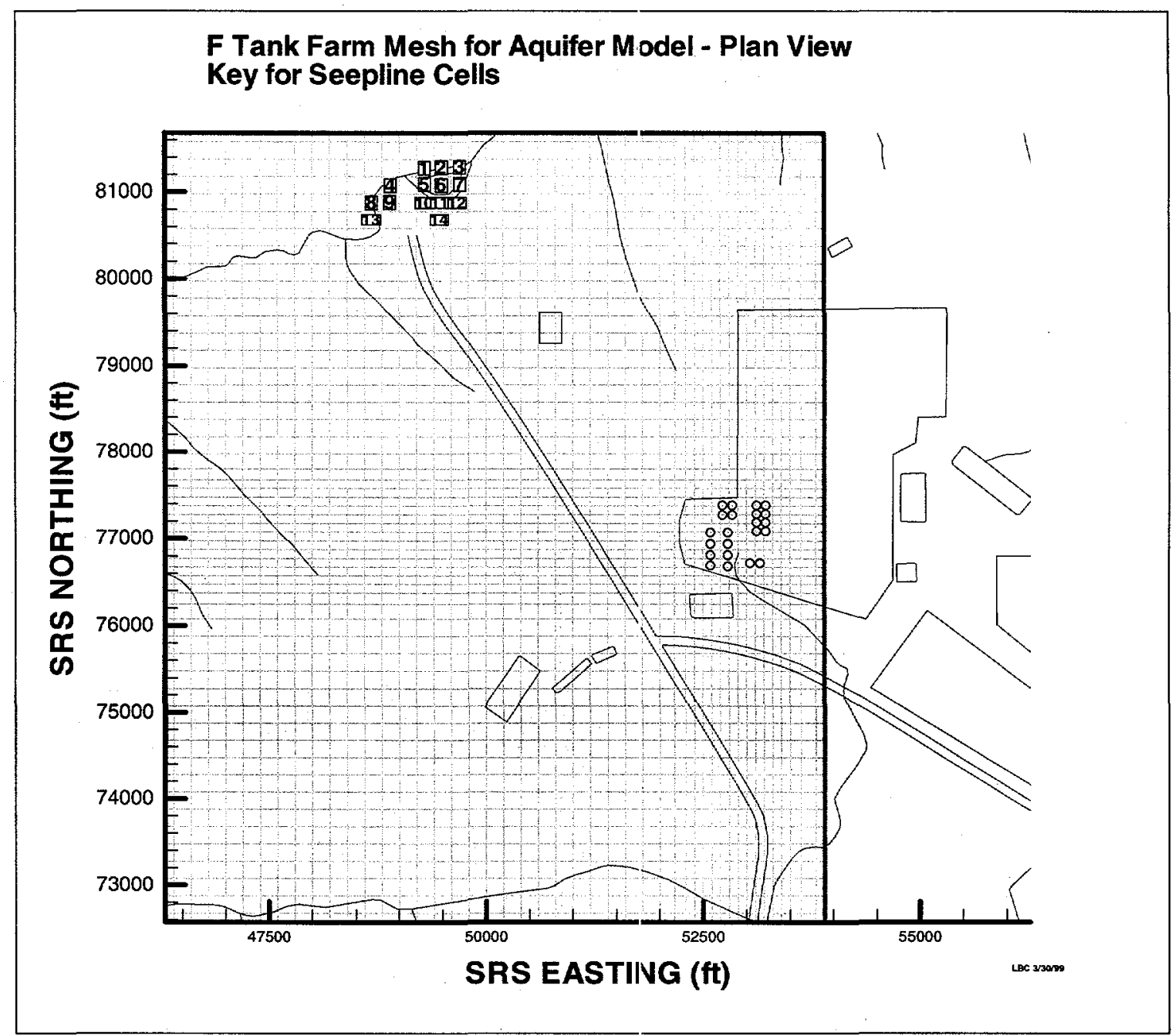

Figure 25A. Key for F-Farm Peak Concentrations in Plan View and Top Ten Peak Concentration Curves 
WSRC-TR-99-00100

September 24, 1999

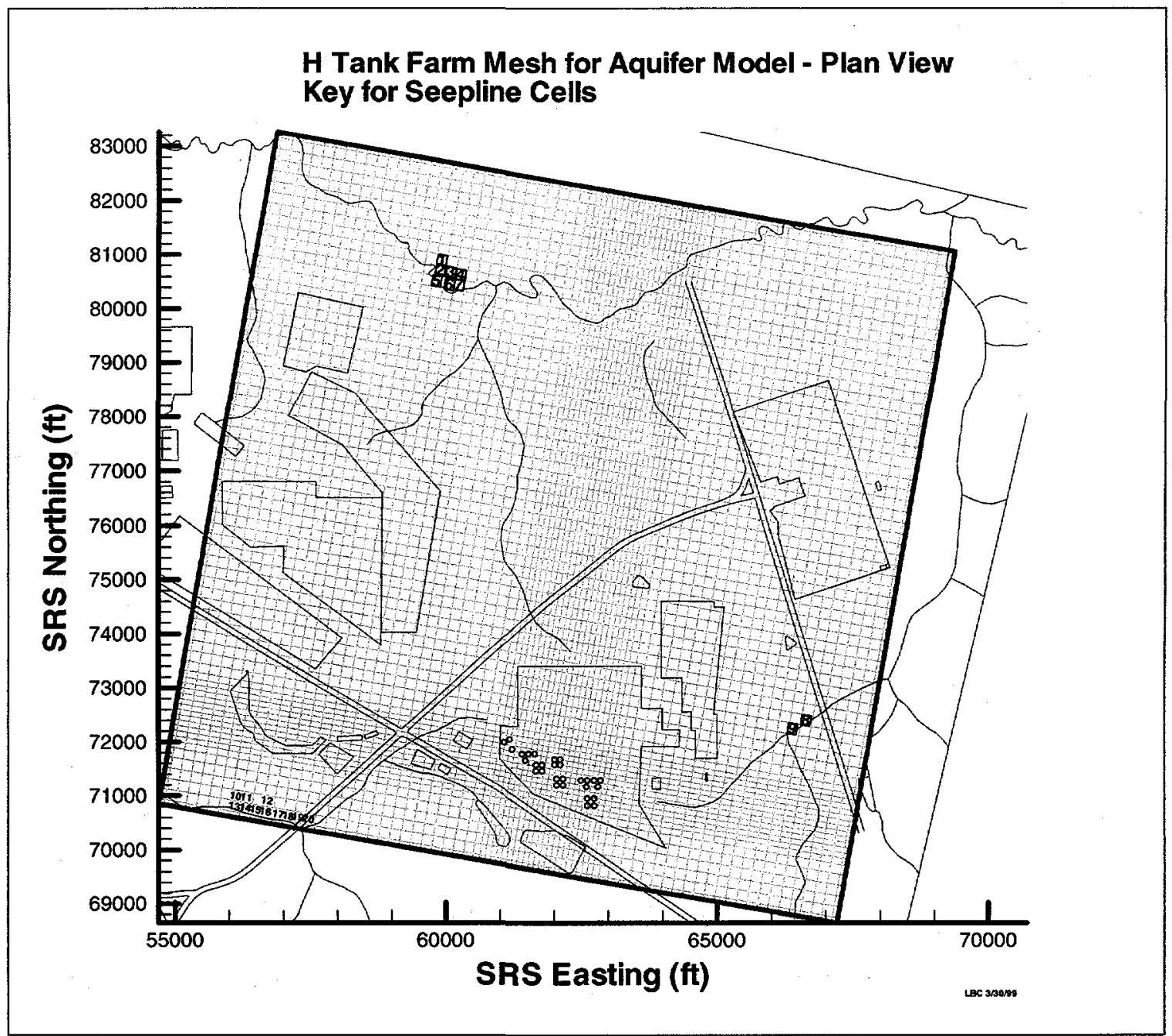

Figure 25B. Key for H-Farm Peak Concentrations in Plan View and Top Ten Peak Concentration Curves 
WSRC-TR-99-00100

September 24, 1999

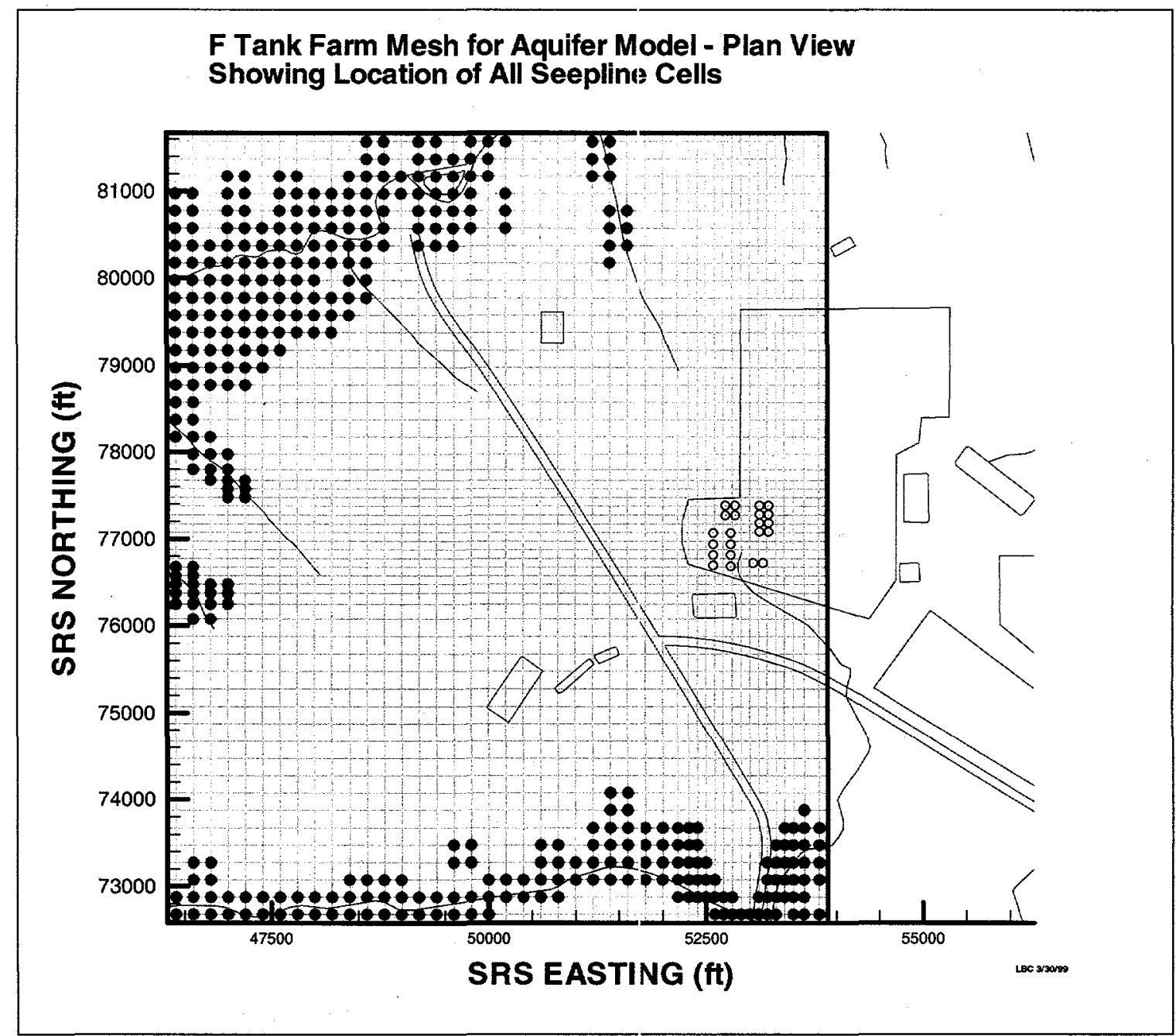

Figure 26A. F-Farm Seepline-Cell Locations in plan view 


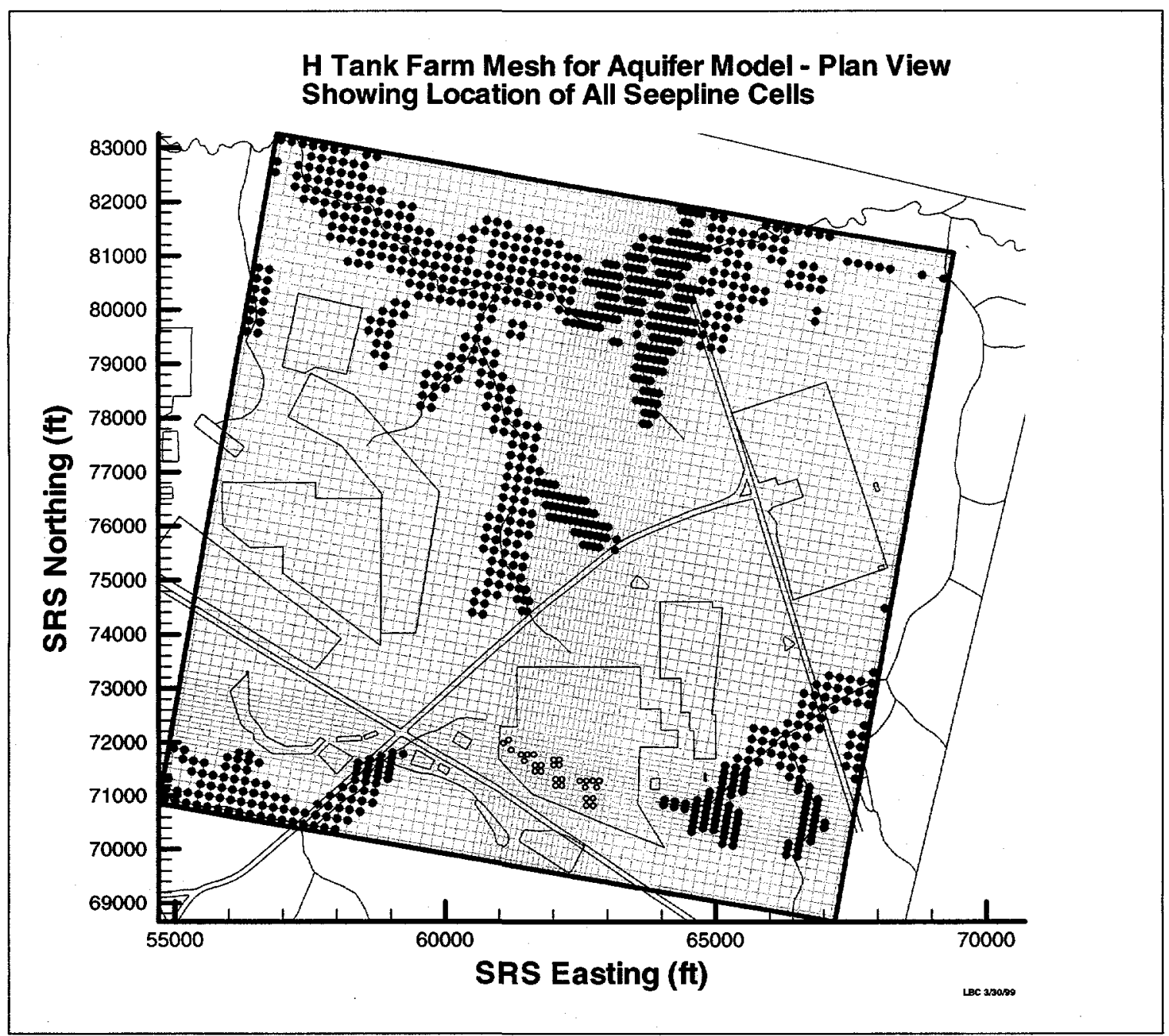

Figure 26B. H-Farm Seepline-Cell Locations in Plan View 


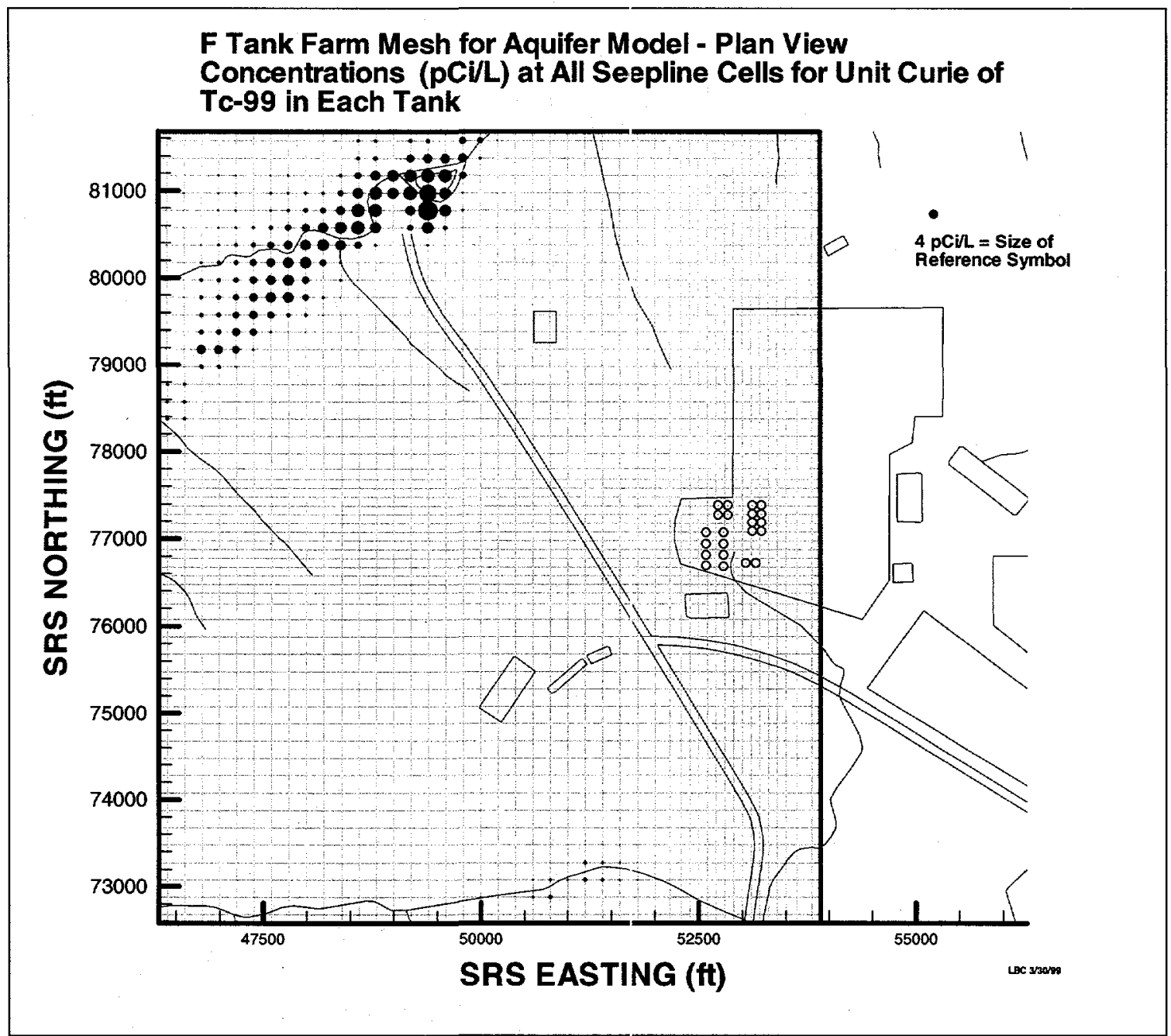

Figure 27. Plan View of F-Farm Tc-99 F'eak-Seepline Concentrations Based on Unit Ci Inventories in All F lanks 


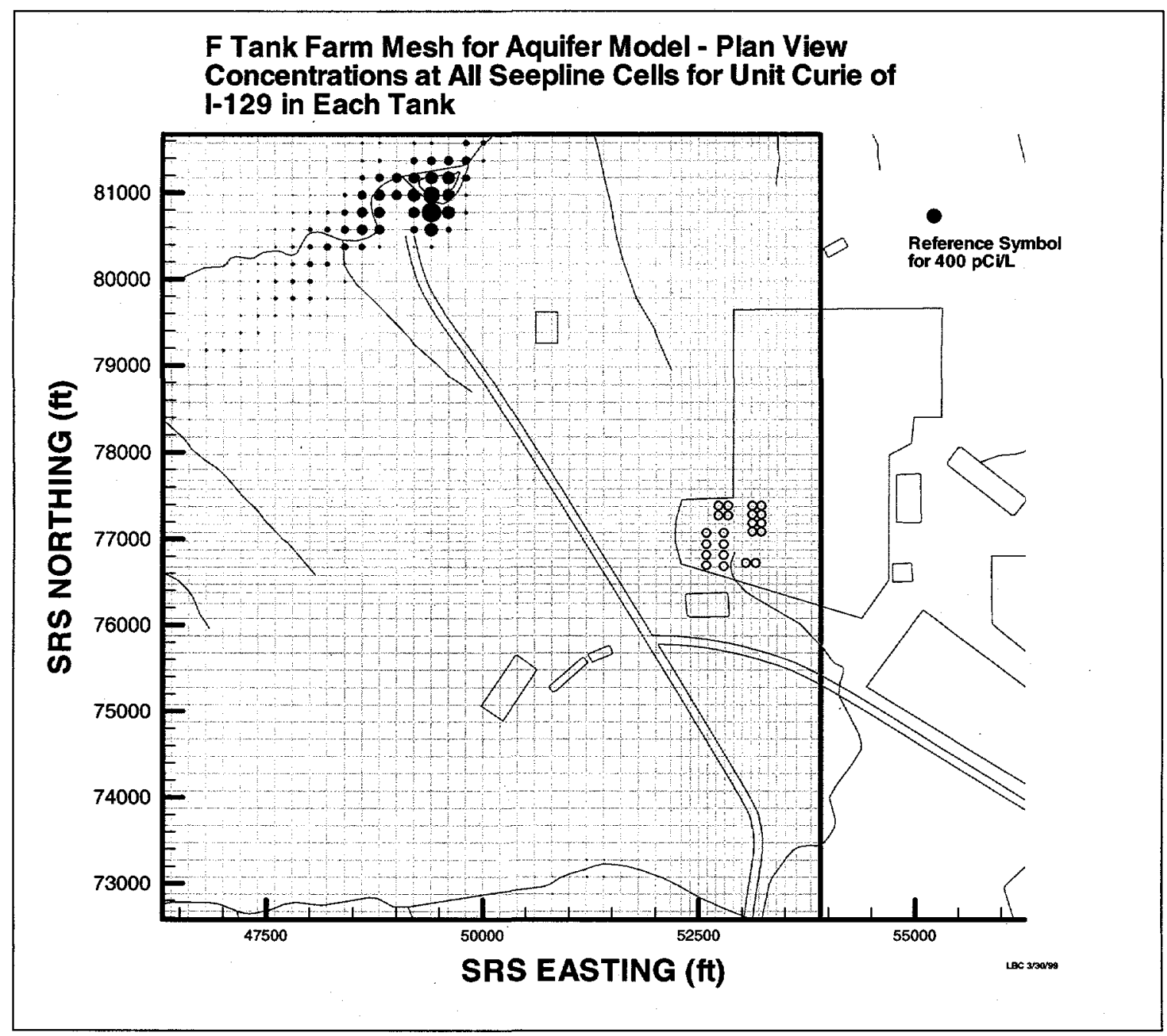

Figure 28. Plan View of F-Farm I-129 Peak-Seepline Concentrations Based on Unit $\mathrm{Ci}$ Inventories in All $\mathrm{F}$ Tanks 
For the Tc-99 in the H-tank farm (see Figure 29), the distributions from the key plot (see Figure 25B) are repeated. For each destination area, the peak concentration diminishes as the distance from the tank farm increases. Crouch Branch in the center of the model displays some high concentrations, although lower than the ten highest-concentration seepline cells. Locations at the eastern-most edges of UTR likely receive contaminants that start heading toward McQueen Branch. These locations are outside the destination range of the streamlines.

For the I-129 in the H-tank farm (see Figure 30), FMB shows the highest concentration levels, with drastically reduced levels along UTR and mere hints of contamination at other destination areas. The quicker release of the I-129 apparently makes it more path-sensitive than Tc99. Part of the difference in the distribution patterns between I-129 and Tc-99 can be attributed to different plot scaling. The symbol sizes in the I-129 figure (Figure 30) are smaller relative to those in the Tc-99 figure (Figure 29), meaning that the lower values shown in the Tc-99 figure will vanish from the I-129 figure.

\subsubsection{Histories for Seepline Cells with the Ten Highest-Peak Concentrations}

For each tank-load combination modeled, the seepline cells with the ten highest concentrations were identified and collected to form one set of cells. Duplicates of cells in the set were discarded.

For the F-Area, the set of high-concentration cells reduced to 14 cells labeled F001 through F014. This set is shown in Figure 25A without the "F" label prefix. All high-concentration cells are closely clustered at UTR, primarily located along the streamlines (see Figure 23) from Tanks 17 through 20 in the northwest part of F-Area.

For the H-Area, the set of high-concentration cells reduced to 20 cells. This set is shown in Figure $25 \mathrm{E}$ without the " $\mathrm{H}$ " label prefix. High-concentration cells H0O1 through H007 are clustered at UTR in the north, primarily located along the streamlines from tanks 9-12 (see Figure 24). High-concentration cells F008 and H009 are located in the east at McQueen Branch along the streamlines from tanks 48-51. Highconcentration cells H010 through H020 are spread along FMB in the south, primarily along streamlines from tanks 13-16 with some contribution from tanks 21 through 24 .

Concentration histories for the F-area high-concentration cells are plotted in Figures 31-35. Concentration histories for the H-area highconcentration cells are plotted in Figires 36-40.

The seepline-concentration curves for c. given scenario generally show similar shapes for each of the top ten cells. Tc-99 curves generally shows lower peaks and gentler slopes than do I-129 curves.

For TC-99 from all F-farm tanks (see Figure 31), the cell with the highest concentration is F011, with F006 being the second highest. F011 appears to be upgradient of F006. F011 is almost the closest cell to the tank farm, indicating the effect of distance on results. 


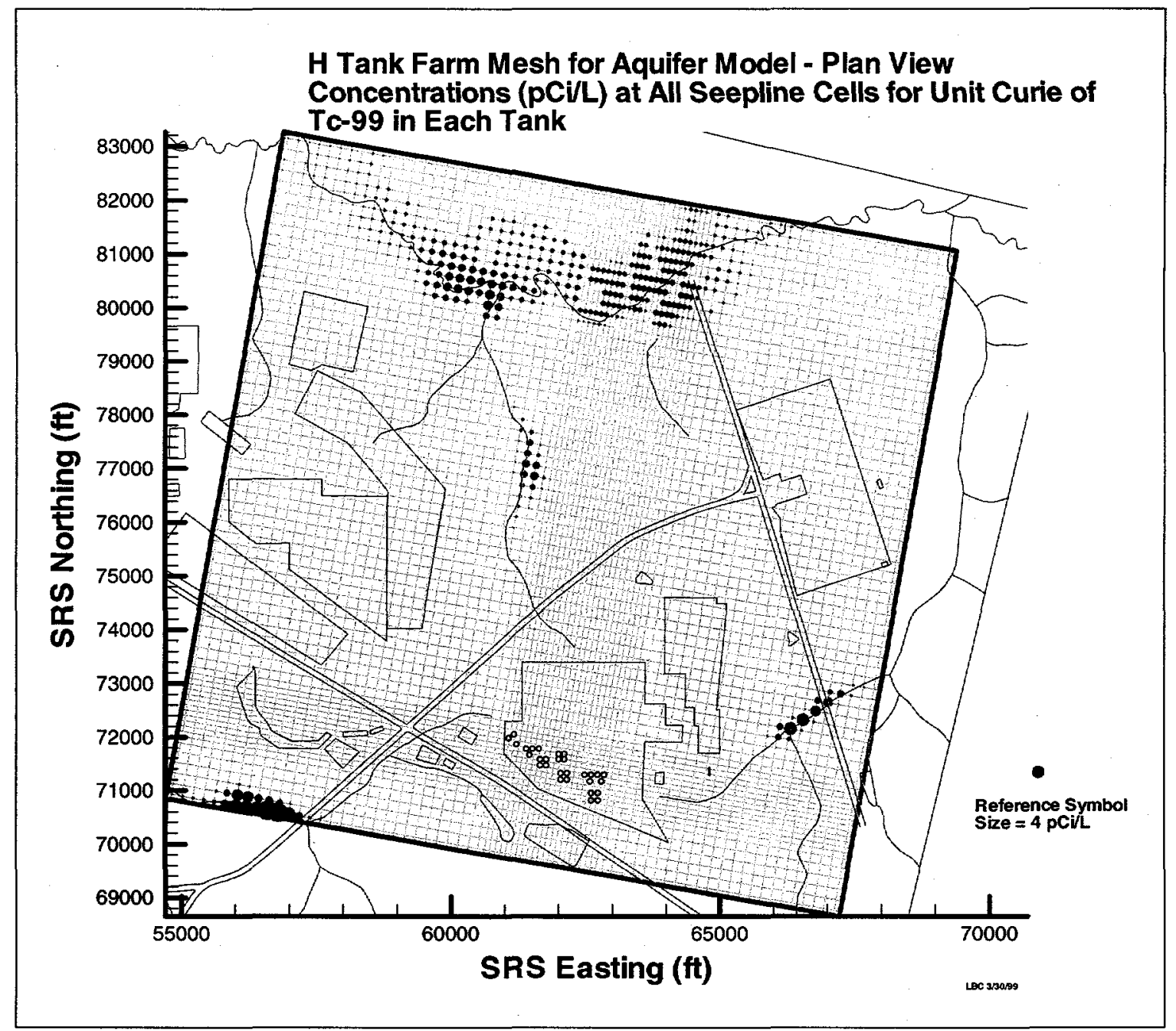

Figure 29. Plan View of H-Farm Tc-99 Peak-Seepline Concentrations Based on Unit Ci Inventories in All H Tanks 


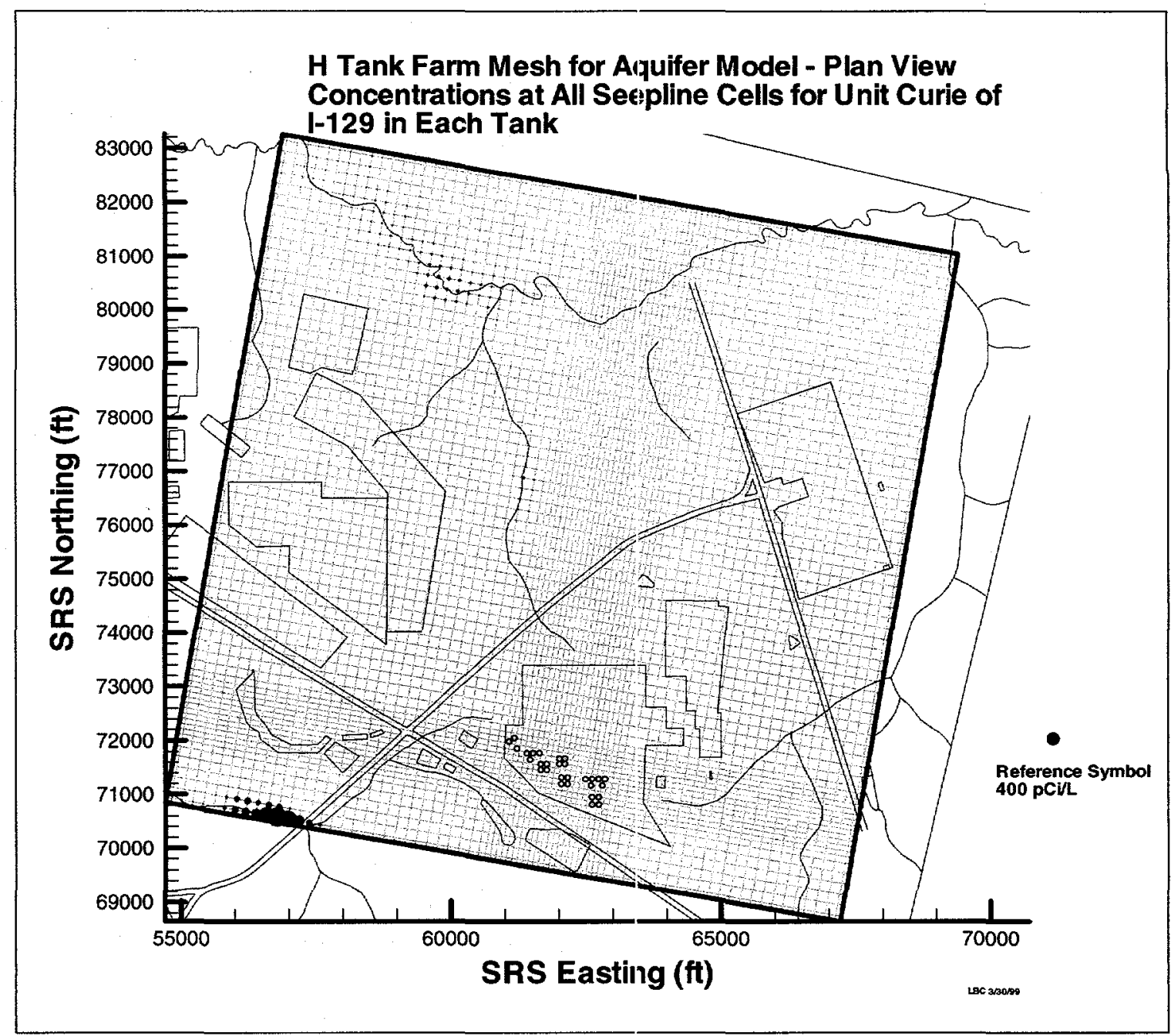

Figure 30. Plan View of H-Farm I-129 Feak-Seepline Concentrations Based on Unit Ci Inventories in All H I'anks 


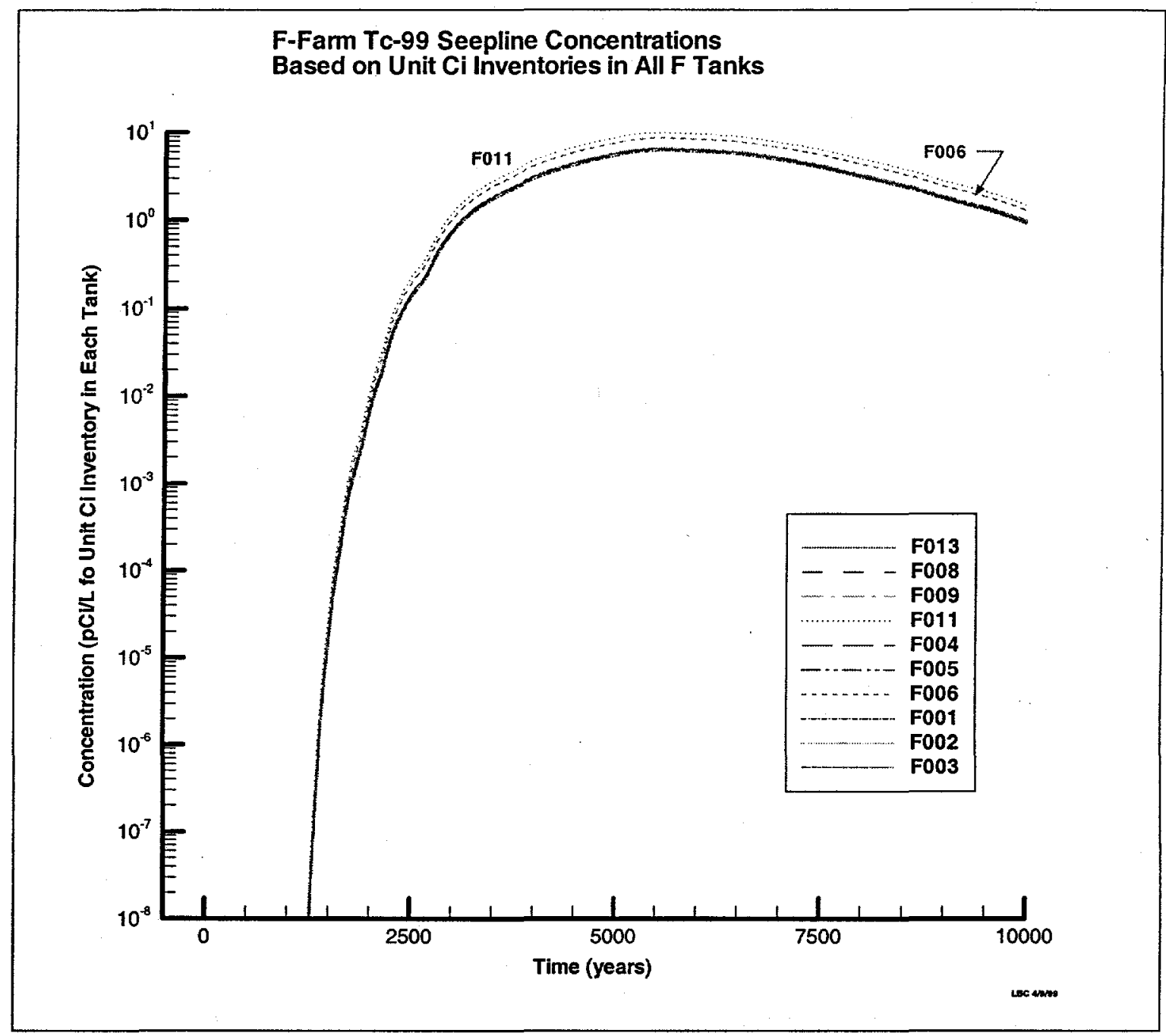

Figure 31. F-Farm TC-99 Top-Ten Seepline-Concentration Curves Based on Unit Ci Inventories in All F Tanks 


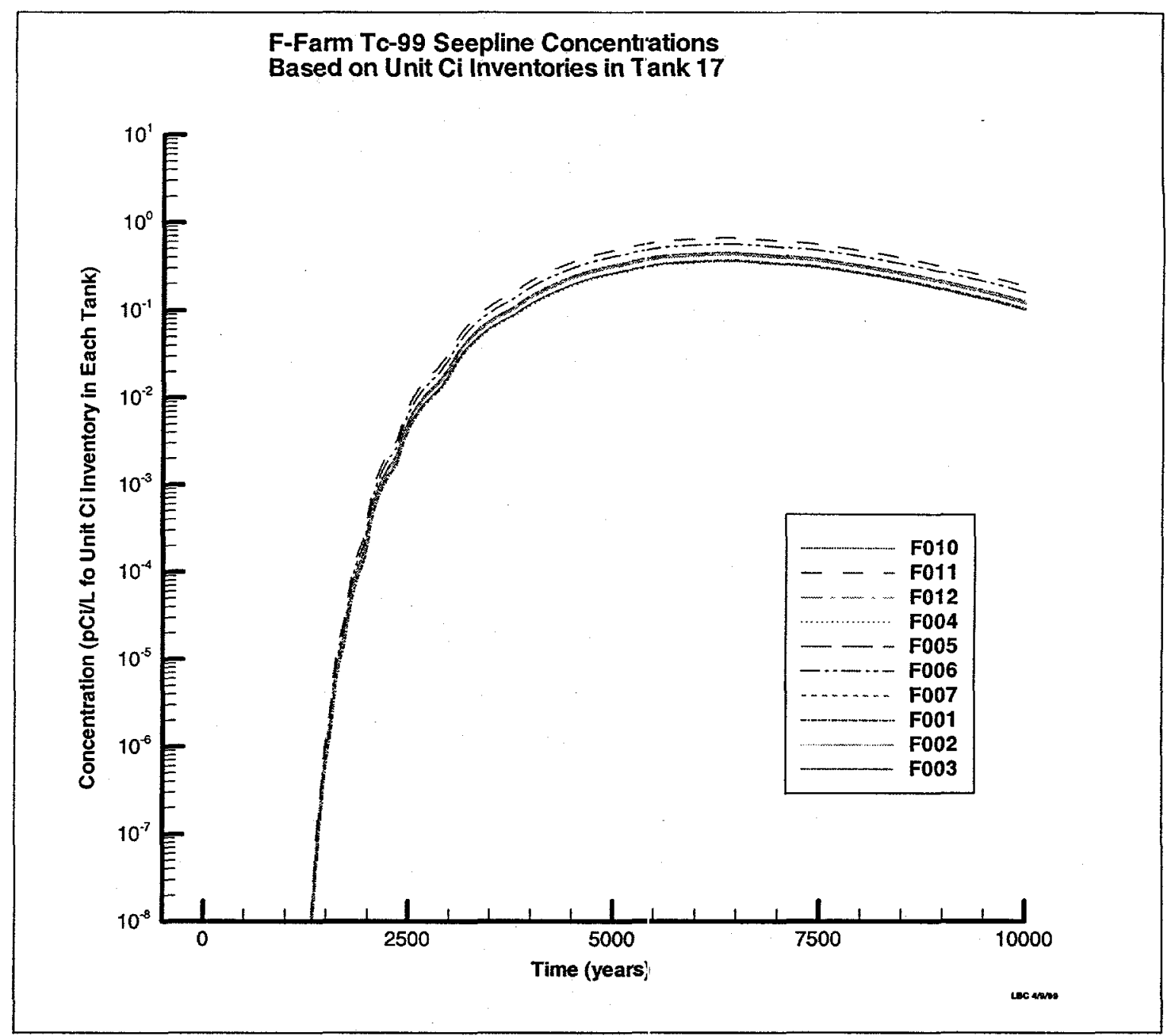

Figure 32. F-Farm TC-99 Top-Ten Seepline-Concentration Curves Based on Unit Ci Inventories in Tank 17 


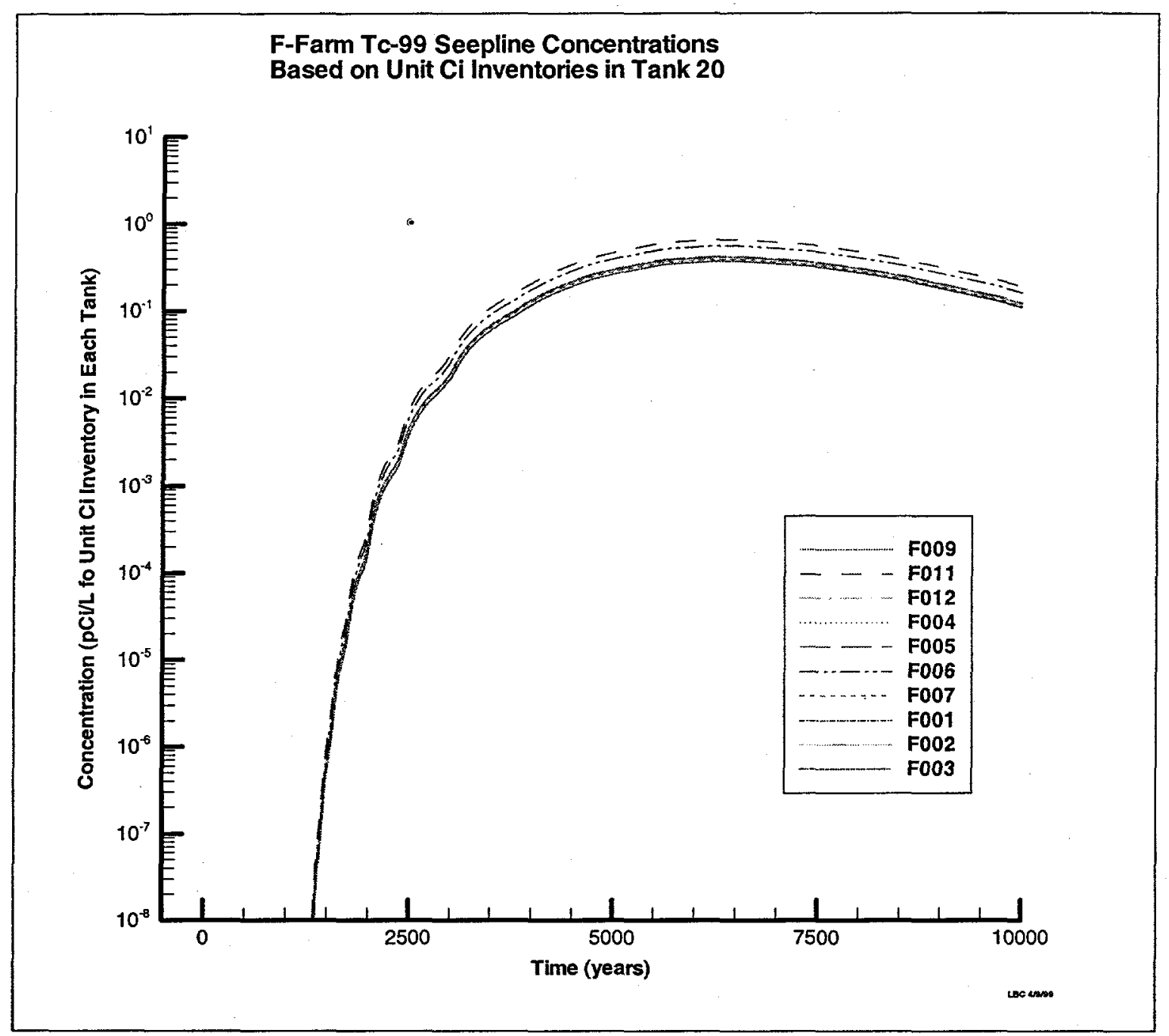

Figure 33. F-Farm TC-99 Top-Ten Seepline-Concentration Curves Based on Unit Ci Inventories in Tank 20 


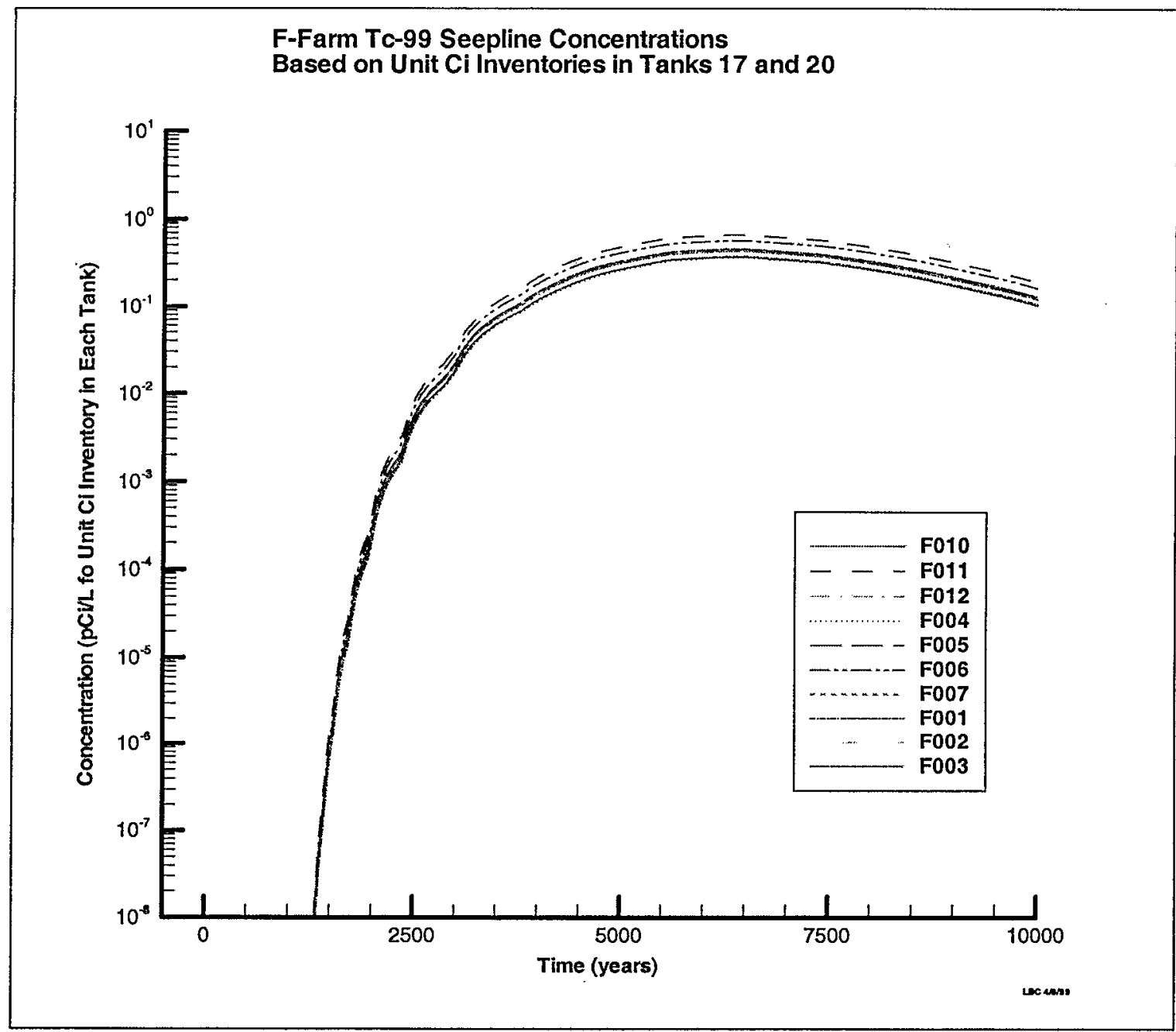

Figure 34. F-Farm TC-99 Top-Ten Seepline-Concentration Curves Based on Unit $C i$ Inventories in Tanks 17 and 20 


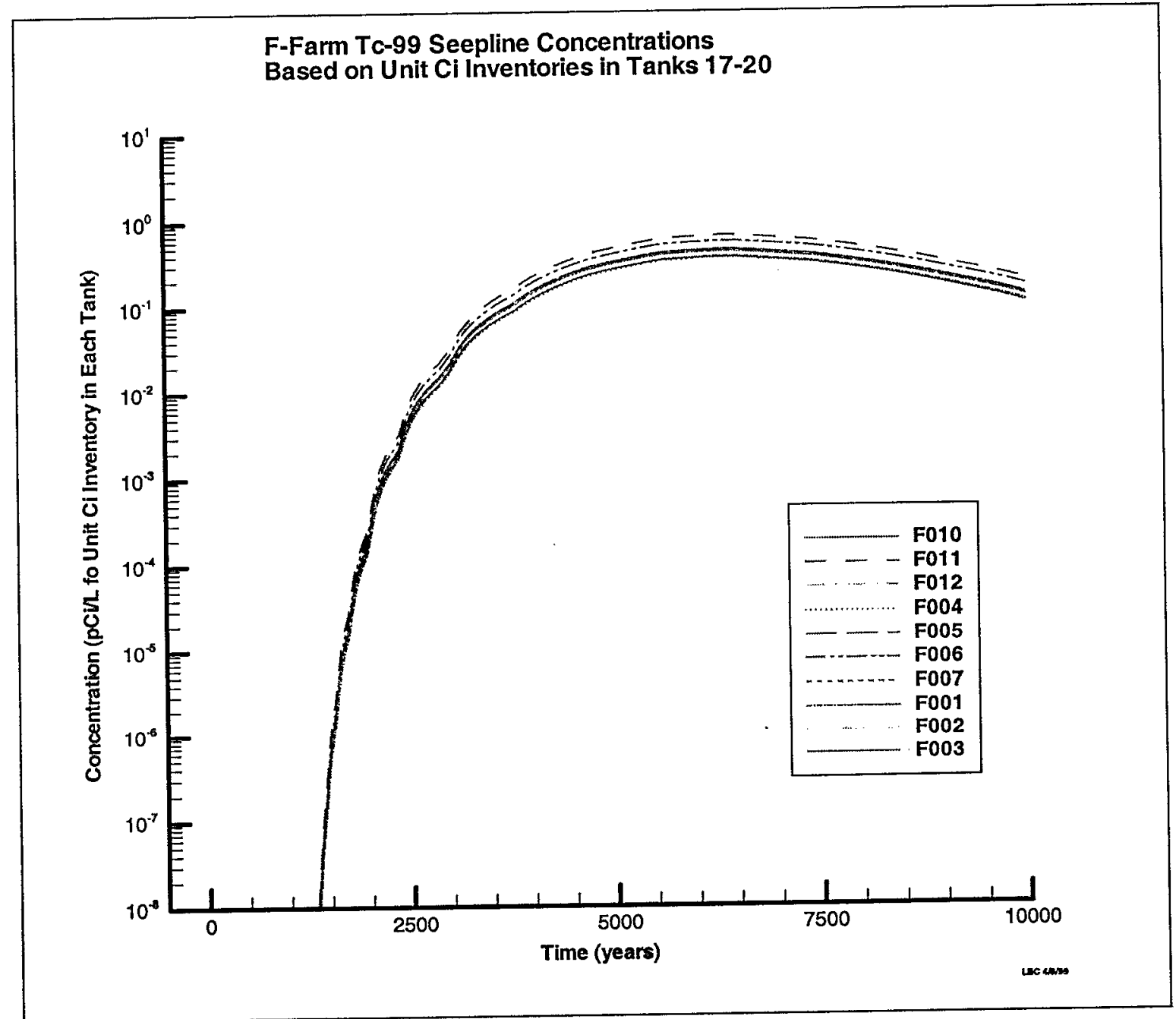

Figure 35. F-Farm TC-99 Top-Ten Seepline-Concentration Curves Based on Unit Ci Inventories in Tanks 17-20 


\section{H-Farm Tc-99 Seepline Concentrations}

Based on Unit Ci Inventories in All H Tanks

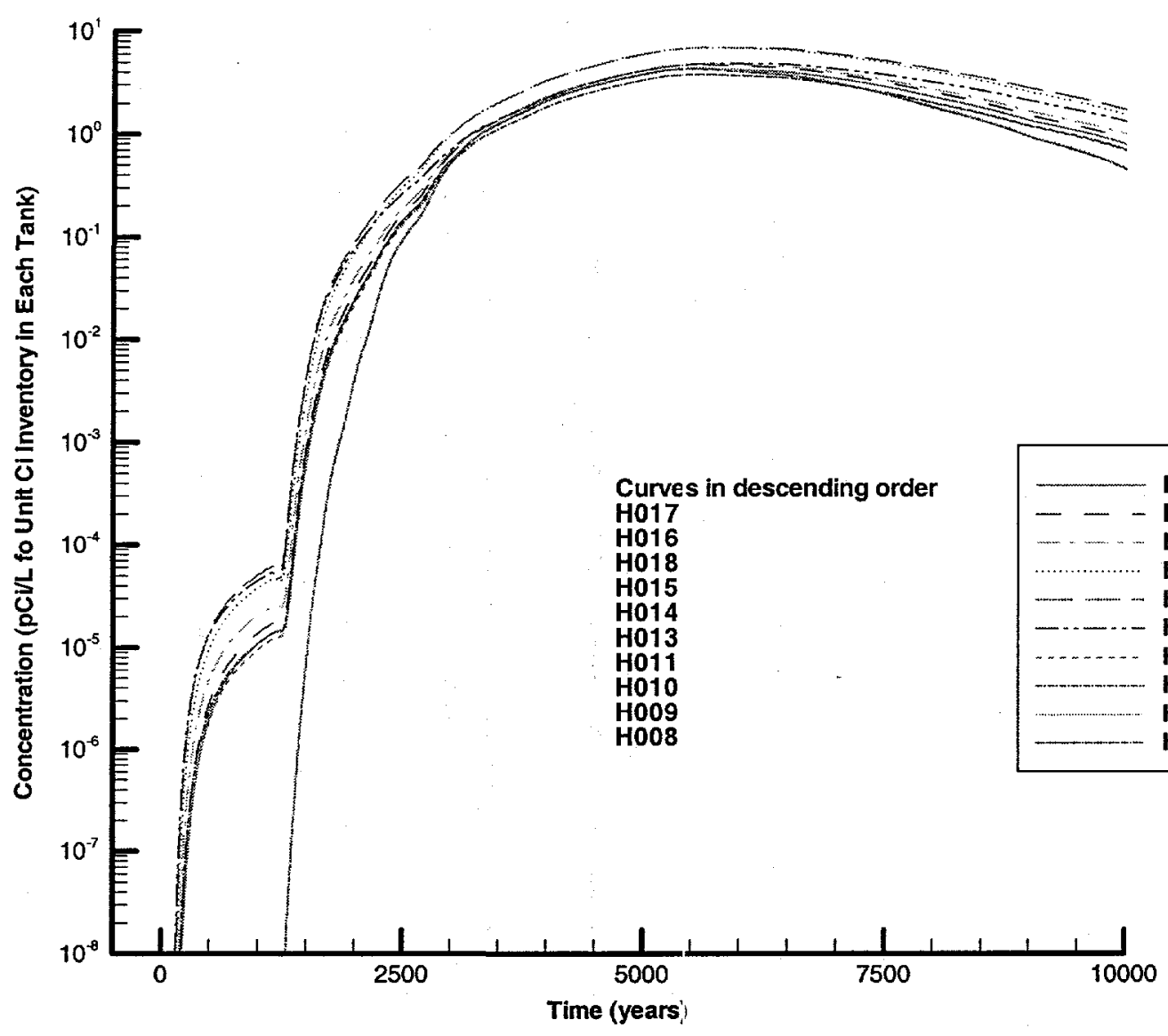

wetmon

Figure 36. H-Farm Tc-99 Top-Ten Seepline-Concentration Curves Based on Unit Ci Inventories in All H Tanks 


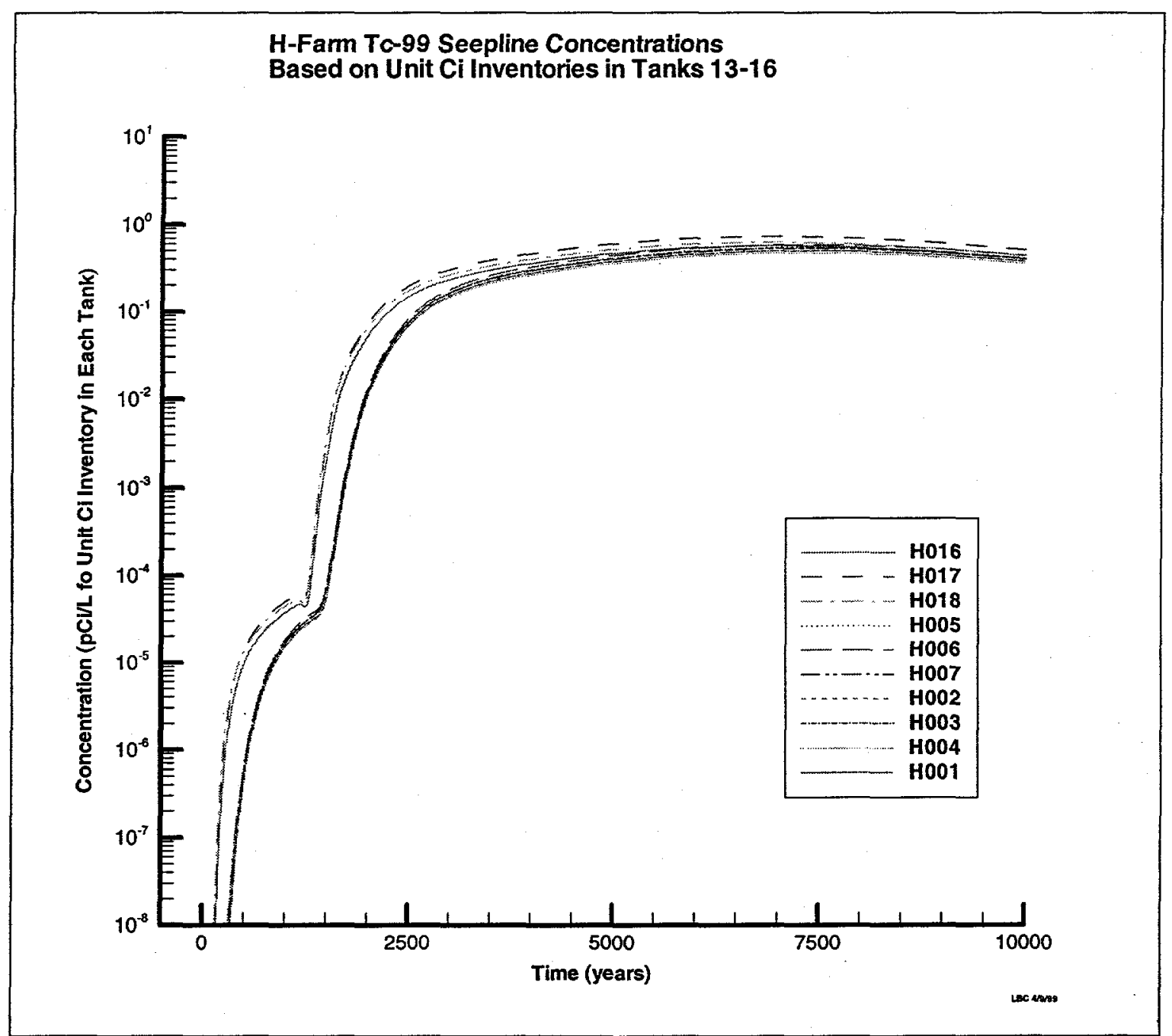

Figure 37. H-Farm Tc-99 Top-Ten Seepline-Concentration Curves Based on Unit Ci Inventories in Tanks 13-16 


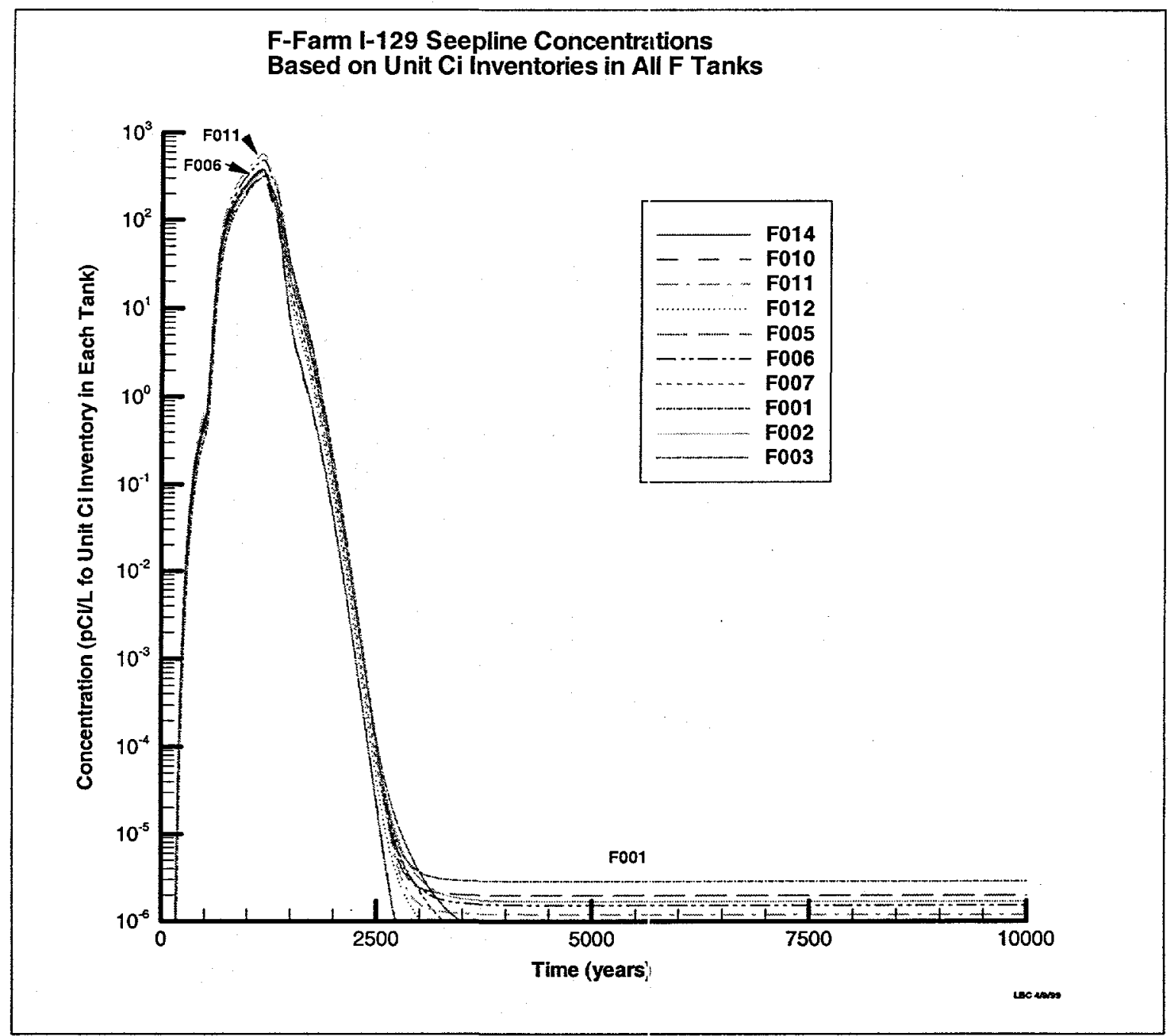

Figure 38. F-Farm I-129 Top-Ten Seepline-Concentration Curves Based on Unit $C i$ Inventories in All $F$ Tanks 


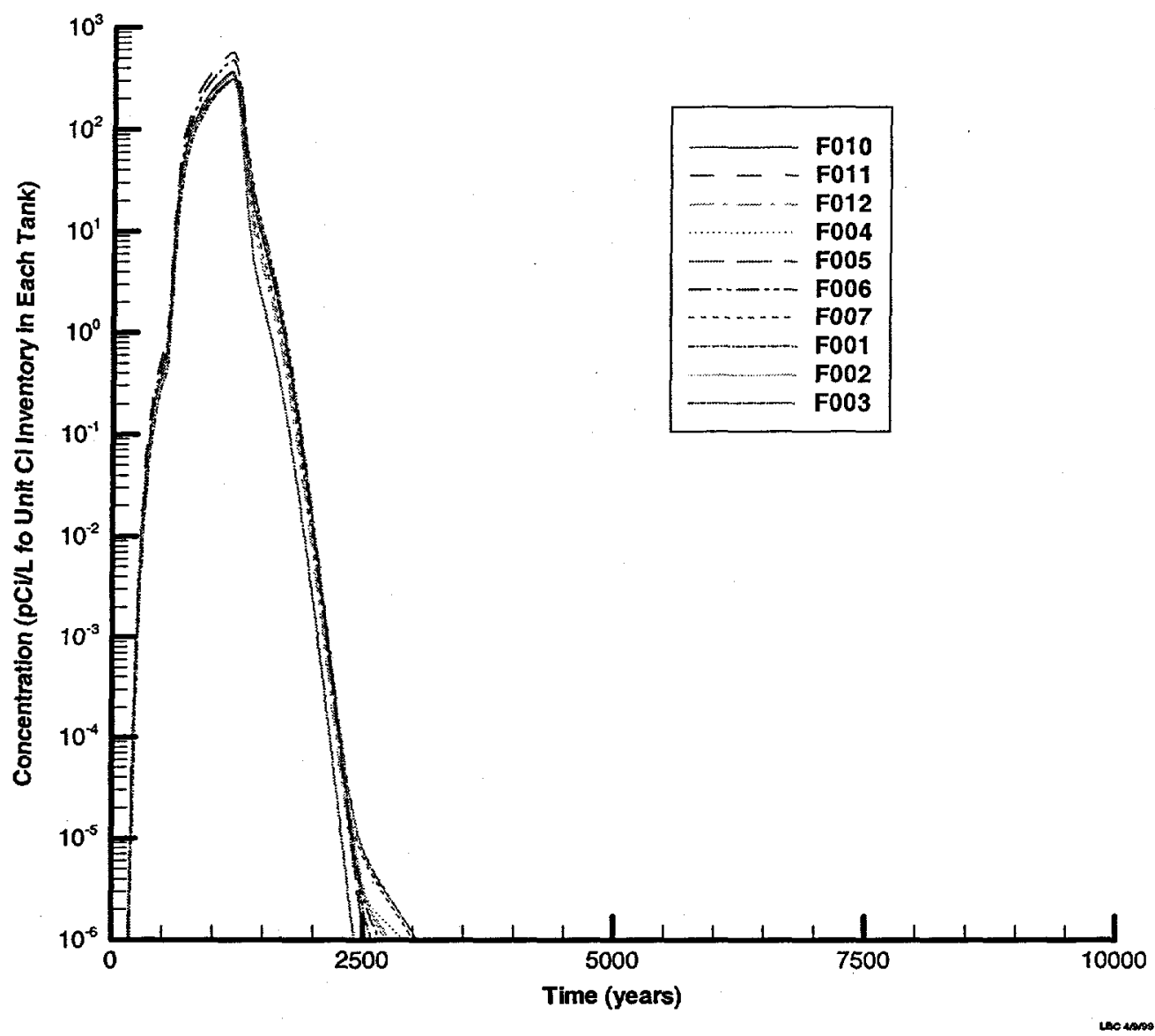

Figure 39. F-Farm I-129 Top-Ten Seepline-Concentration Curves Based on Unit $C i$ Inventories in Tanks 17-20 


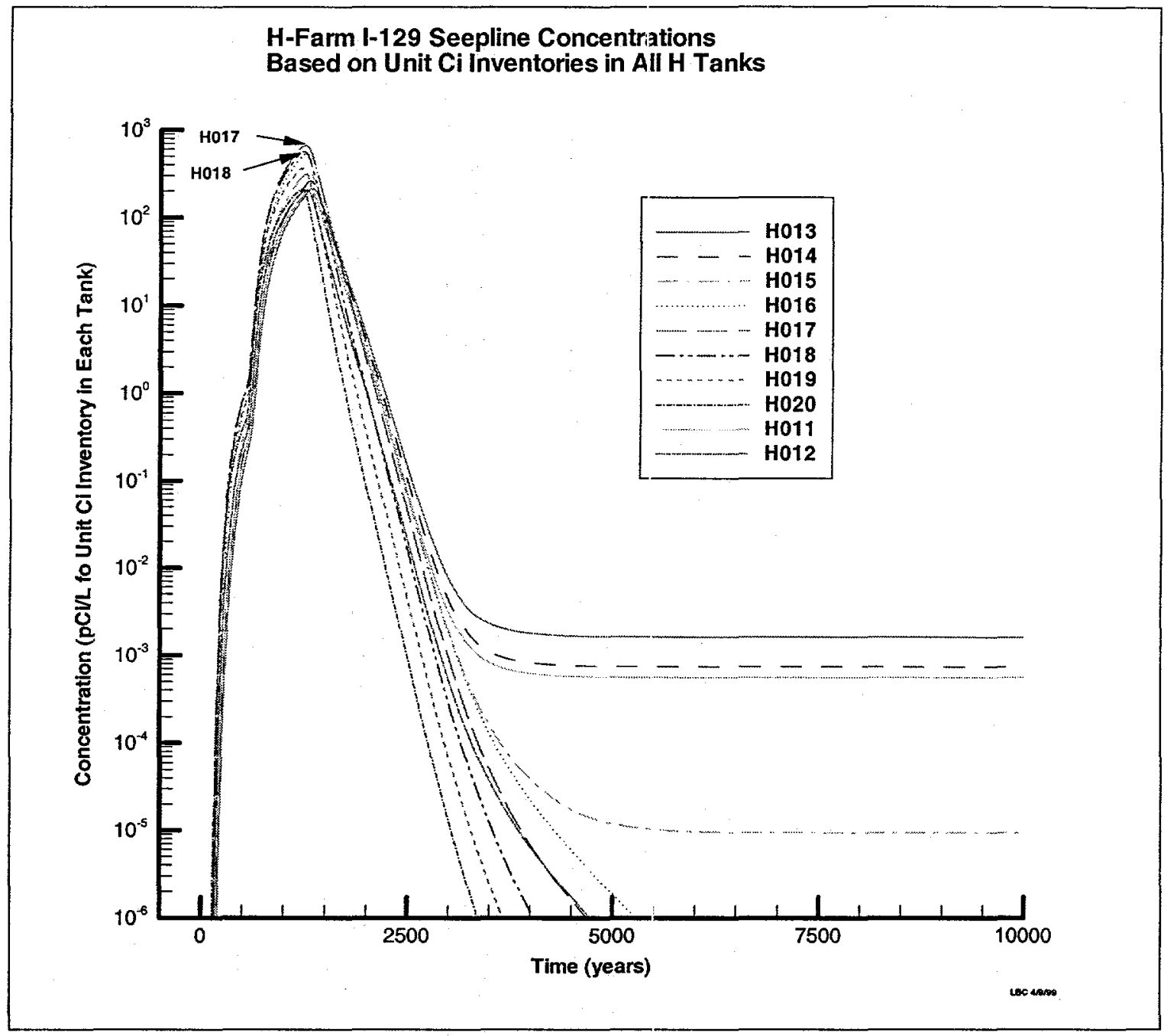

Figure 40. H-Farm I-129 Top-Ten Seepline-Concentration Curves Based on Unit Ci Inventories in A.I H Tanks 
For Tc-99 from Tank 17 in the F-tank farm (see Figure 32), the highest concentration cell is F011 followed by F006. This is the same pattern shown for the entire tank farm, but the peak concentrations are lower, suggesting plumes from other tanks overlap the Tank 17 plume.

The highest concentrations occur at F011 and F006 for Tc-99 from Tank 20 (see Figure 33), from Tanks 17 and 20 (see Figure 34), and from Tanks 17-20 (see Figure 35). The curve shapes mimic those for Tank 17.

For TC-99 from all H-farm tanks (see Figure 36), a different curve shape emerges. Contaminants arrive at H017 and H016 along FMB much earlier than they reach seepline cells in the F-tank farm. Slopes reduce significantly after about 700 years, then rapidly rise after about 1200 years. The curve shapes are similar to that for the Tank 1316 fluxes to the aquifer (see Figure 20). It is likely that the tanks with waste below the water table have a relatively larger impact on early seepline concentrations than do tanks that are above the water table.

For Tc-99 from Tanks 13-16 in the H-tank farm (see Figure 37), the concentration curve is similar to that for all tanks in the H-tank farm. The two highest-concentration curves (H017 and H016) are almost identical for both load cases for the first 1500 years. After 1500 years, the curves for all $\mathrm{H}$-farm tanks continue to rise, suggesting contributions from other tanks affect the seepline concentrations during that period.

For I-129 from all F-farm tanks (see Figure 38), F011 and F006 exhibit the highest peaks. This pattern follows that for Tc-99. The I-129 curves peak much earlier and more sharply than do the Tc-99 curves.

For I-129 from Tanks 17-20 in the F-tank farm (see Figure 39), the curves are very similar to those for all tanks in the H-farm. A noticeable difference is that the Tanks 17-20 curve essentially disappears from the plot after about 3,000 years, while the all-H-farmtanks curve (see Figure 40) diminishes to a low residual seeplineconcentration level that continues for the entire simulation period. This residual behavior does not agree with the contaminant fluxes to the aquifer (see Figures 19 through 232). It may be an artifact of selecting a subset of the contaminant fluxes to the aquifer for loading the aquifer, but the residual is about six orders of magnitude below the peaks, so its impact is negligible.

For I-129 from all-H-farm tanks (see Figure 40), H017 and H018 along FMB exhibit the highest peaks. This is a slightly different order of high-peak cells than for TC-99 (Figure 36) where H017, H016 and H018 displayed the highest peaks. This curve does not display the same early shape as does TC-99, probably because the I-129 flux to the water table for the waste below the water table behaves differently than does the Tc-99 (see Figure 20). The I-129 reaches a short-term peak very early, then gradually decreases until about 1,000 years, while the Tc99 never achieves an early peak. The effect of the concrete failure is evident as the slope of the I-129 seepline concentration curve increases at about 1,000 years. The I-129 seepline-concentration curves for the H-tank farm display much higher residuals than do the same curves for the F-tank farm. H013 and H014 display the highest residuals along FMB, so less dilution and longer travel times will 
occur for those cells than for seepline cells in the F-tank farm where travel occurs through the Gordon aquifer with higher velocities.

\subsubsection{Plume Interaction}

Seepline concentrations created by a single four-pack of tanks were compared with the concentrations created by all tanks to determine the extent of plume interaction. A set of tanks was modeled and the results from the highest-concentration seepline cell from that model were compared against the results from a model consisting of all tanks in the same tank farm. Plume interaction comparisons are plotted as shown in Table 5. The comparison can only show the potential for plume interaction, not the actual amount, because all tanks were loaded with the same inventory, not the expected residual amounts.

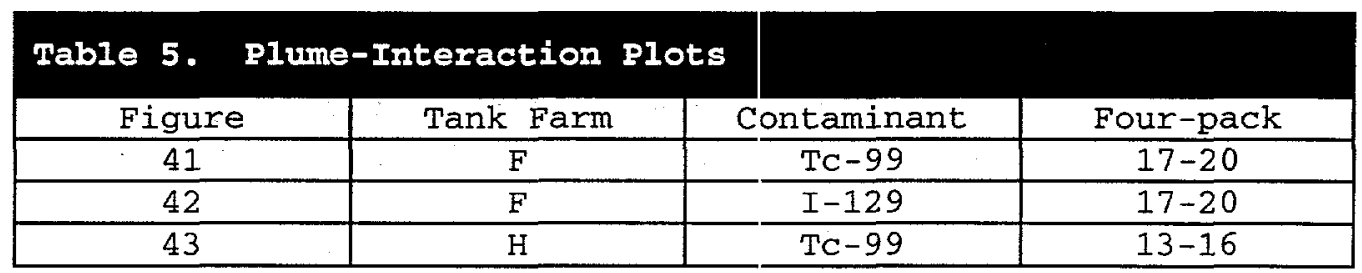

For the F-tank farm the Tank 17-20 four-pack was modeled using TC-99. Its highest-concentration seepline-cell history is plotted in Figure 41 versus the history at the same seepline cell for the all-F-farm-tanks model. The peak for all the tanks is about one-half order of magnitude greater than the peak for only Tanks 17-20. This suggests significant plume interaction between other tanks and Tanks 17-20.

For the F-tank farm the Tank 17-20 four-pack also was modeled using I129. Figure 42 displays those results. The results indicate that Tanks 17-20 reached a higher peak. This is not possible, but is probably the result of numerical dispersion. The curves are essentially identical on the upslope and the downslopes are quite similar. If the peaks were the same, the downslopes would be very similar. The similarity between curves indicates that little plume interaction likely occurs for I-129, at least at the peak seepline cell.

Rerunning the analyses using smaller time steps, especially during the time when the peaks occurred, can reduce the numerical dispersion causing the incorrect peaks. With its faster release, I-129 results are more sensitive than TC-99, but the same time steps were used to solve both models.

For the H-tank farm, the Tank 13-16 four-pack was modeled using Tc-99. Its highest-concentration seepline-cell history is plotted in Figure 43 versus the history at the same seepline cell for the all-H-farm-tanks model. The peak for all the tanks is about one order of magnitude greater than the peak for only Tanks 13-16. This suggests significant plume interaction between other tanks and Tanks 13-16. 


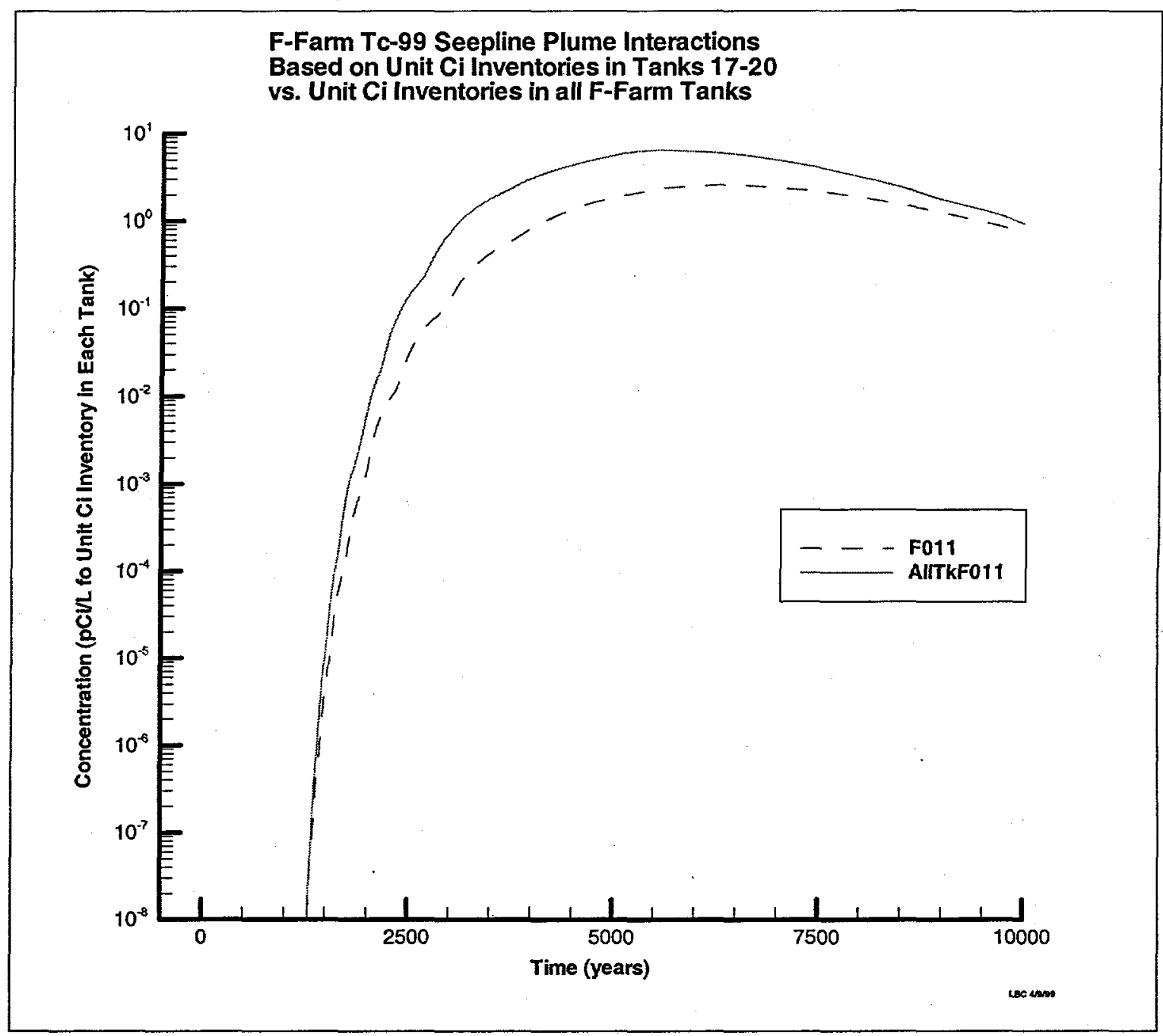

Figure 41. F-Farm Tc-99 Plume Interaction for Tanks 17-20 vs. Entire Farm 


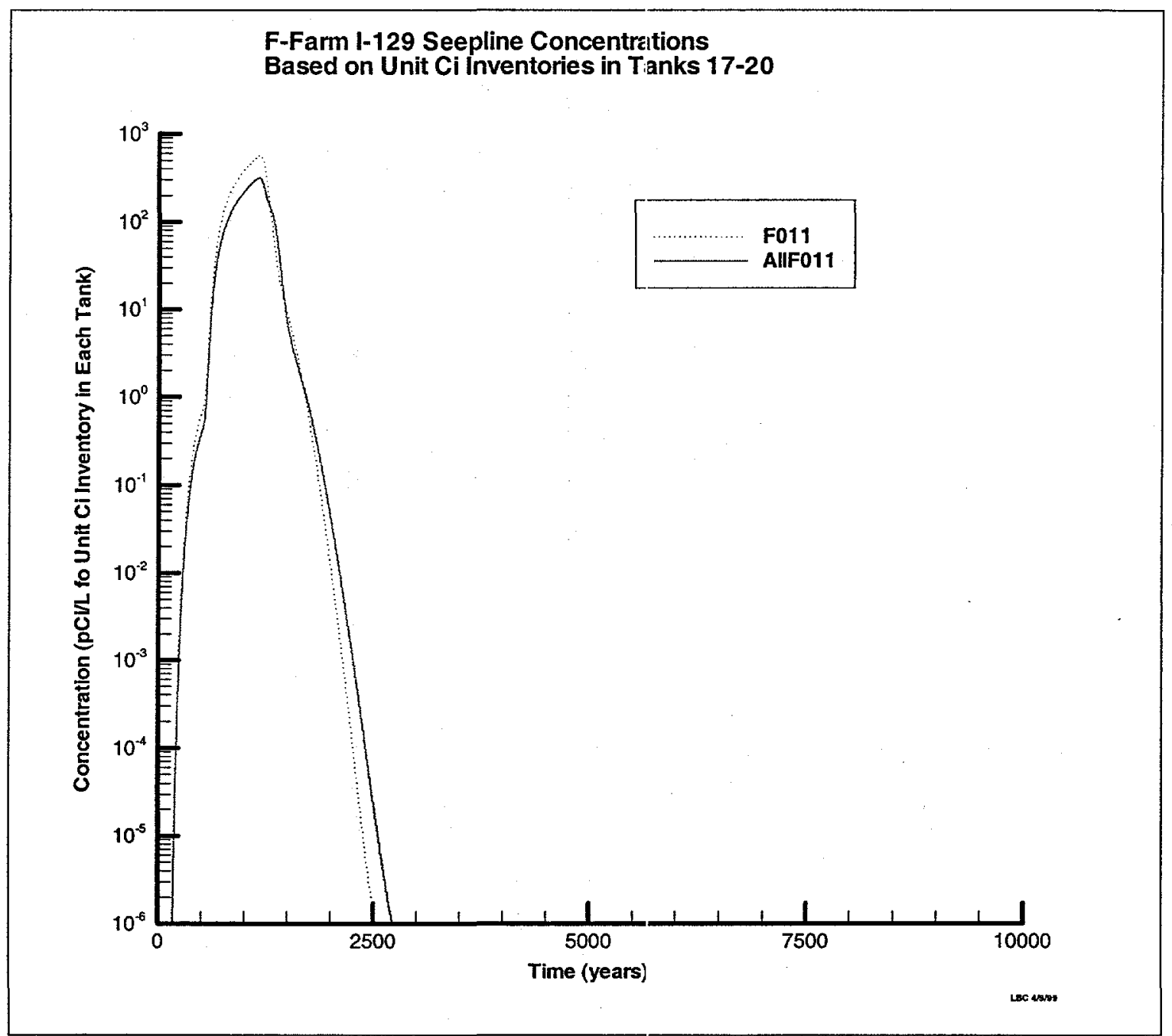

Figure 42. F-Farm I-129 Plume Interaction for Tanks 17-20 vs. Entire Farm 


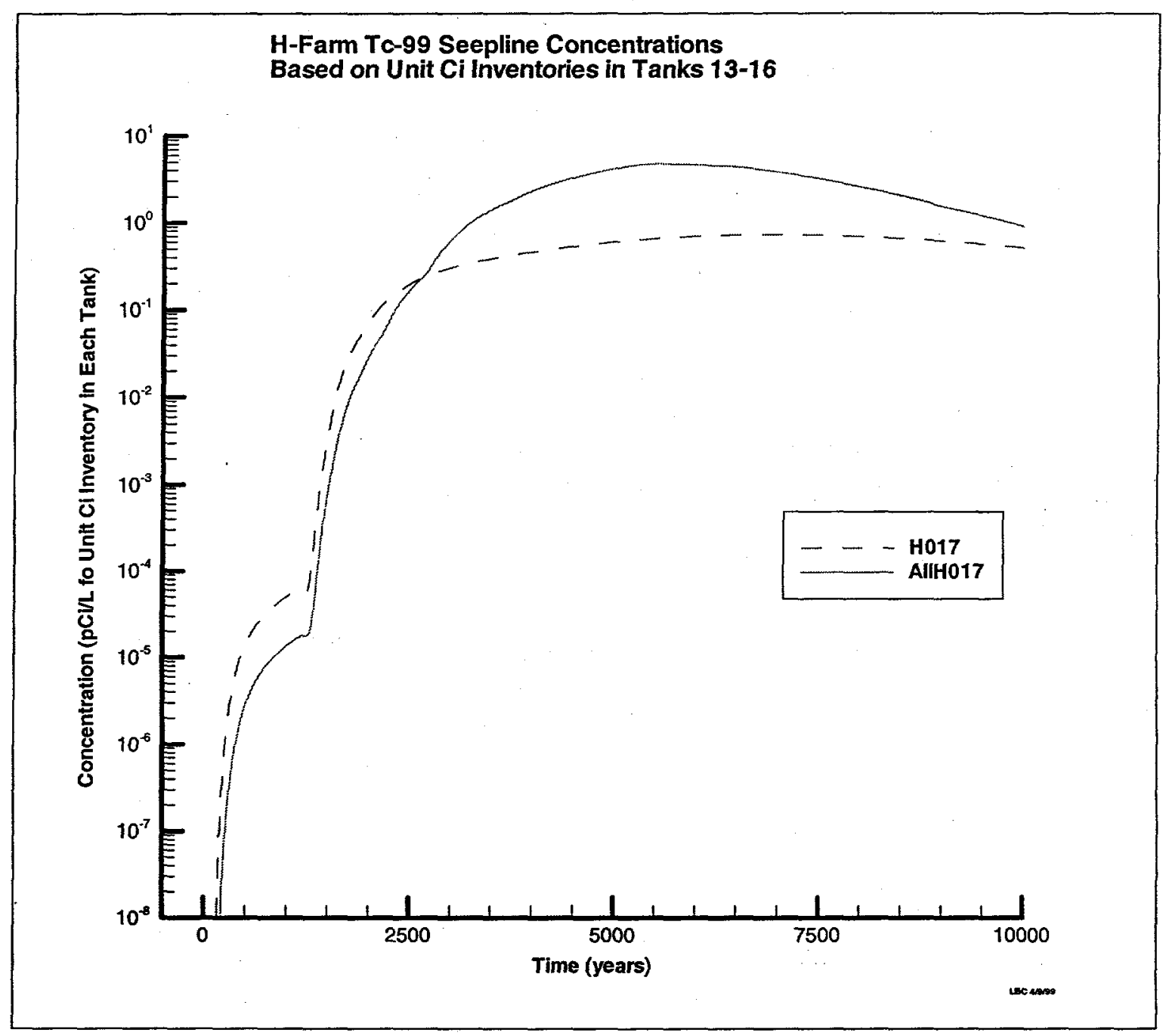

Figure 43. F-Farm TC-99 Plume Interaction for Tanks 13-16 vs. Fntire Farm 


\subsubsection{Diffusion Comparison}

The Rapid Screening Tool should properly account for diffusion. One study was made to examine the effects of diffusion. Tc-99 from Tank 17 was modeled independently, as was Tc-99 from Tank 20. The sum of the seepline results from these models is plotted in Figure 44 versus the seepline results for a model that simultaneously considers Tc-99 from Tanks 17 and 20 . No differences between the two curves are discernable; indicating either that diffusion is properly accounted for during superposition or that diffusion is insignificant in the aquifer models for TC-99 at seepline cell F011.

\subsubsection{Tank 17 and 20 Absolute Results}

After separately modeling the Tc-99 load in Tanks 17 and 20 with a revised tank basemat thickness of 0.58 Eeet, the seepline concentrations were scaled by the reported inventory. The results for the peak concentration found among all the seepline cells at any time during the simulation period are shown in Table 6 . Table 6 contains the results for Tanks 17 and 20 and the results from earlier onedimensional modeling for Tank 17 (DOE, :.997C) and Tank 20 (DOE, 1997a).

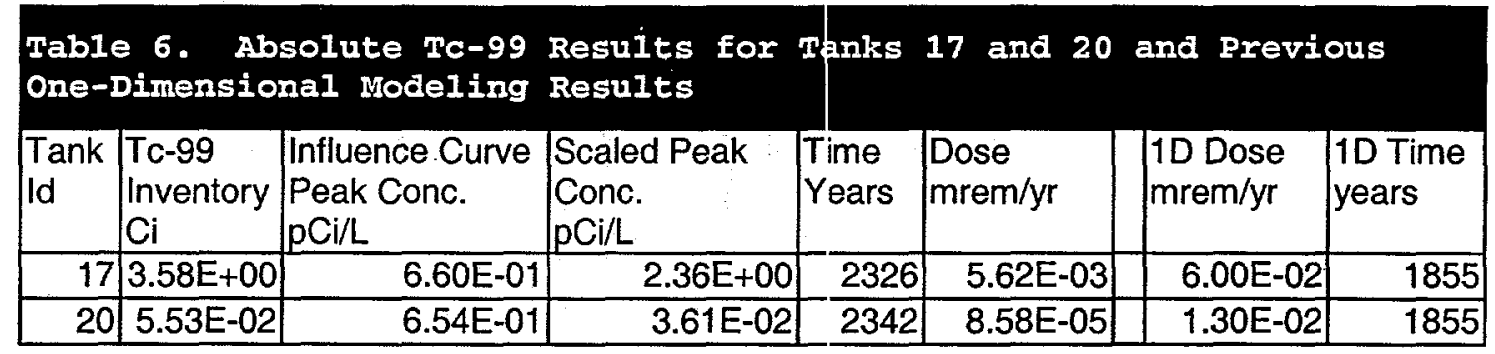

Table 6 indicates that the influence curves are essentially the same for both tanks: peak concentrations varied by about one percent, the peak time varied by only 16 years, and both peaks occurred after 2,000 years. The ratio between the doses, 65.5:1, for the two tanks is within about one percent of the ratio between the initial inventories, 64.7:1. Tanks 17 and 20 have a thin vadose zone underlying them, thus the one-foot-thick vadose-zone category was applied to them.

Doses from the multi-dimensional modeling are less than doses calculated from the one-dimensional modeling in both cases. For Tank 17 the difference is one order of magnitude and for Tank 20 the difference is about three orders of magnitude. 


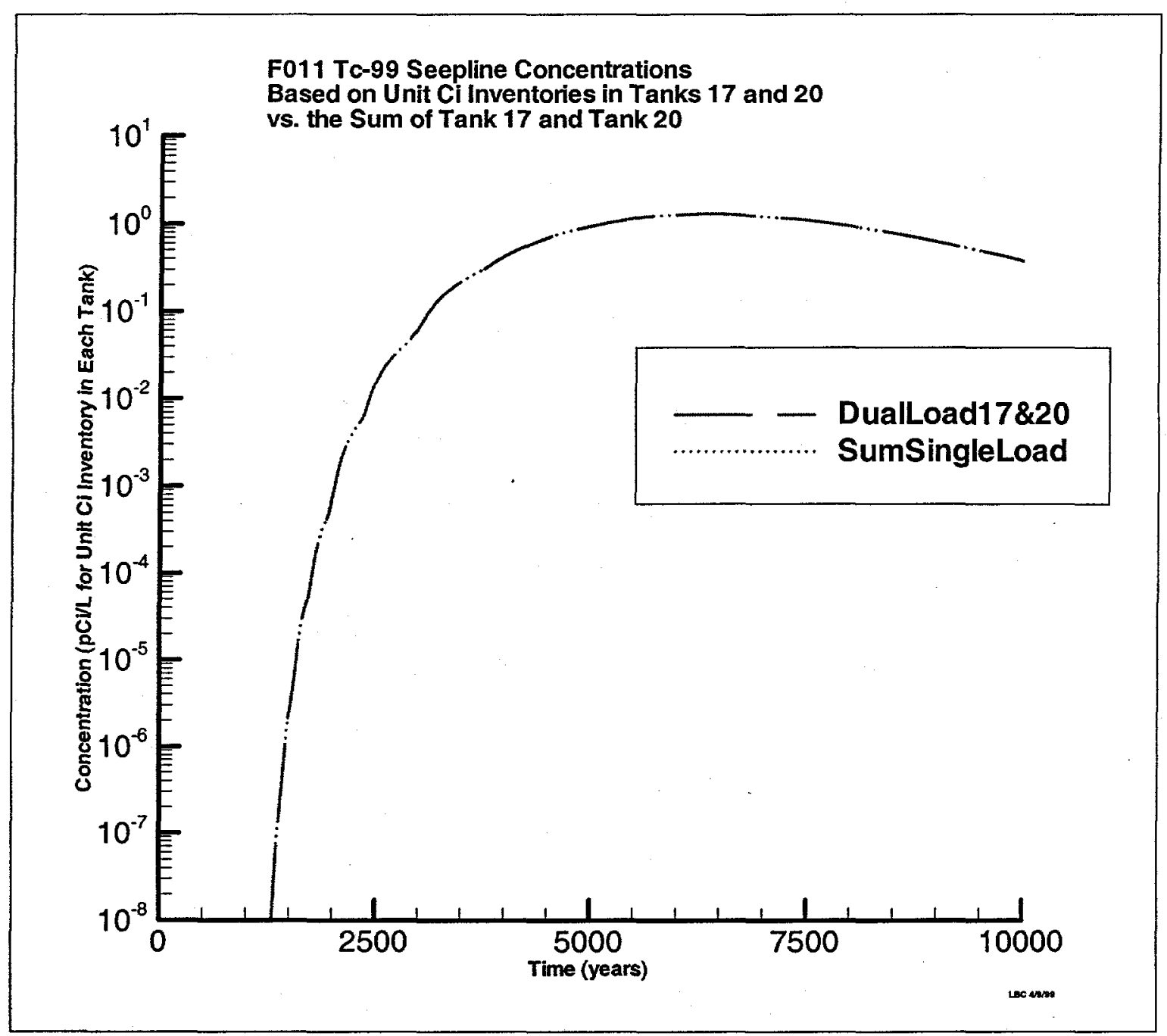

Figure 44. Diffusion Comparison for Dual Load of Tanks 17 and 20 vs. Sum of Individual Loads 


\subsection{Summary and Conclusions}

A suite of multi-dimensional models was completed to analyze the transport of residual contamination from high-level waste tanks through the subsurface to seeplines. These models especially take full advantage of an existing aquifer-flow model using detailed, sitespecific data. These models allow full consideration of plume interaction among tanks, without the need for a highly conservative approach of assuming complete overlap. The models have been tested with two radionuclides that are often of concern for performance assessments, TC-99 and I-129.

The initial pieces have been developed for a Rapid Screening Tool that can allow a fuller understanding of the effects of different residual contaminant inventories in tanks, without having to completely redo modeling analyses. The Rapid Screening Tool will require a significant amount of initial work to completely populate a large database, but the subsequent use can be very important. Jif high amounts of residual contamination are found in a tank and a decision needs to be made about further cleaning, the Rapid Screening Trol can quickly show most of the effects of the higher residuals. The possibility of cleaning other tanks can be studied and compared against cleaning the tank that was most recently characterized.

Tanks with wastes below the water table have been directly modeled as being in the aquifer. This type of analysis requires multi-dimensional modeling to produce reasonable results.

All the seepline cells in each model have been identified and can be monitored. A new feature in PORFLOW allows the program to check all the seepline cells at each time step to ensure that the peak cells are being monitored. This feature allows the number of monitoring cells to be reduced to save disk storage space, while ensuing that the peak cell is not missed.

Comparisons with one-dimensional modeling performed for tank closures indicate that the three-dimensional modeling provided lower concentrations at the seepline at a different location and a different time. The three-dimensional results for two adjacent tanks were more consistent than the one-dimensional modeling results, when compared to the ratio of the contaminant inventories in the tanks. 


\subsection{REFERENCES}

ACRi, 1998, PORFLOW, A Software Tool for Multiphase Fluid Flow, Heat and Mass Transport in Fractured Porous Media, USER'S MANUAL, VERSION 4.00, Analytical \& Computational Research, Inc., 1931 stradella Road, Bel Air, California.

Collard, 1998, PORFLOW Capabilities, Usage History, and Testing, WSRCRP-98-00311, MaY 6 .

DOE (U.S. Department of Energy), 1996, Industrial Wastewater Closure Plan for $F$ - and H-Area High-Level Waste Tank Systems, Savannah River operations office, Aiken, South Carolina, July 10, Rev. 1.

DOE (U.S. Department of Energy), 1997a, Industrial Wastewater Closure Module for the High-Level Waste Tank 20 System, Savannah River Operations Office, Aiken, South Carolina, January 8, Rev. 1.

DOE (U.S. Department of Energy), 1997b, Composite Analysis, E-Area Vaults and Saltstone Disposal Facilities, WSRC-RP-97-311, Westinghouse Savannah River Company, Aiken, South Carolina, September, Rev. 0 .

DOE (U.S. Department of Energy), 1997c, Industrial Wastewater Closure Module for the High-Level Waste Tank 17 System, Savannah River Operations Office, Aiken, South Carolina, August 26, Rev. 2.

DOE (U.S. Department of Energy), 1998, Draft Radiological Performance Assessment for the E-Area Low-Level Waste Facility, Vol. II, Appendices A through $F$, WSRC-RP-94-218, Westinghouse Savannah River Company, Aiken, South Carolina, September, Rev. 0 .

Flach, G. P. and M. K. Harris, 1999, Integrated Hydrogeological Model of the General Separations Area, Volume 2: Groundwater Flow Model (U). WSRC-TR-96-0300, Westinghouse Savannah River Company, Aiken, South Carolina, April, Rev. 1.

Flach, G. P., 1999, Pre- and Post-processing Software Associated with the GSA/FACT groundwater Flow Model (U), WSRC-TR-99-00106, Westinghouse Savannah River Company, Aiken, South Carolina, April, Rev. 0.

Freeze, R. A. and J. A. Cherry, 1979, Groundwater, Prentice-Hal1, Inc., Englewood Cliffs, New Jersey.

WSRC, 1997. GIMS Reports, http: //pleiades.srs.gov/GIMS/, Westinghouse River Company, Aiken, SC.

Yu, A. D., C. A. Langton and M. G. Serato, 1993, Physical Properties Measurement Program, WSRC-RP-93-894, Westinghouse Savannah River Company, Aiken, South Carolina, June. 
APPENDIX A

\begin{tabular}{|l|l|}
\hline \multicolumn{2}{|l|}{ Table A-1. Radionuclide Half-Lives } \\
\hline Radionuclide & Half-Life (Years) \\
\hline Tc-99 & $2.13 \mathrm{E} 5$ \\
\hline $\mathrm{I}-129$ & $1.57 \mathrm{E} 7$ \\
\hline
\end{tabular}

\begin{tabular}{|c|c|c|c|c|c|}
\hline \multirow[t]{2}{*}{ Description } & \multicolumn{2}{|c|}{ Concrete } & \multicolumn{2}{|l|}{ Waste } & \multirow{2}{*}{$\begin{array}{l}\text { Native } \\
\text { Soil }\end{array}$} \\
\hline & Intact & Failed & Intact & Failed & \\
\hline Dry Bulk Density $(\mathrm{g} / \mathrm{cc})$ & 1.99 & 1.99 & 1.99 & 1.99 & 1.54 \\
\hline $\begin{array}{l}\text { Vertical Hydraulic conductivity } \\
(\mathrm{cm} / \mathrm{s})\end{array}$ & $1 E-9$ & $1 E-5$ & $1 E-9$ & $1 E-5$ & $1 E-5$ \\
\hline $\begin{array}{l}\text { Horizontal Hydraulic Conductivity } \\
(\mathrm{cm} / \mathrm{s})\end{array}$ & $1 E-9$ & $1 E-5$ & $1 E-9$ & $1 E-5$ & $1 E-5$ \\
\hline Effective Porosity & .25 & .25 & .25 & .25 & .42 \\
\hline
\end{tabular}

Table A-3. Transport Parameters for Vadqse zone Models
\begin{tabular}{|l|l|l|l|}
\hline Description & Concrete & Waste & $\begin{array}{l}\text { Native } \\
\text { Soil }\end{array}$ \\
\hline Dry Bulk Density (g/cc) & 1.99 & 1.99 & 1.54 \\
\hline Molecular Diffusion (cm^2/s) & $1 . \mathrm{c}-6$ & $1 . \mathrm{E}-6$ & $1 . \mathrm{E}-6$ \\
\hline Longitudinal Dispersion (ft) & .03 to .01 & .01 & .01 to \\
\hline Total Porosity & .25 & .25 & .42 \\
\hline
\end{tabular}

\begin{tabular}{|l|l|l|l|}
\hline Table A-4. Distribution Coefficients for & Vadose Zone Models (ml/g) \\
\hline Radionuclide & Concrete & Waste & $\begin{array}{l}\text { Native } \\
\text { Soil }\end{array}$ \\
\hline Tc-99 & 1000 & 1000 & .36 \\
\hline$I-129$ & 2 & .6 & .6 \\
\hline
\end{tabular}

Table A-5. Transport Parameters for Aquifer Models
\begin{tabular}{|l|l|l|}
\hline Description & Sand & Clay \\
\hline Dry Bulk Density (g/cc) & 1.99 & 1.99 \\
\hline Molecular Diffusion (cm^2/s) & $5 . \mathrm{E}-6$ & $2.5 \mathrm{E}-6$ \\
\hline Longitudinal Dispersion (ft) & 0.0 & 0.0 \\
\hline Total Porosity & .25 & .25 \\
\hline Tc-99 Kd (ml/g) & .36 & 1.0 \\
\hline $\mathrm{I}-129 \mathrm{Kd} \mathrm{(ml/g)}$ & 0.6 & 1.0 \\
\hline
\end{tabular}

\footnotetext{
${ }^{2}$ Numerical dispersion is large enough that additional dispersion through dispersivity is not needed
} 